\title{
COGNITIVE, EXPERIENTIAL AND GENETIC CONTRIBUTION TO DEPRESSIVE SYMPTOMS IN MALE AND FEMALE STUDENTS WITH A HISTORY OF CONCUSSION by
}

\section{Kaylyn Ann Dixon}

A thesis submitted to the Faculty of Graduate and Postdoctoral Affairs in partial fulfillment of the requirements for the degree of

\author{
Master of Science \\ in \\ Neuroscience \\ Carleton University \\ Ottawa, Ontario
}

(C) 2016

Kaylyn Ann Dixon 


\begin{abstract}
Mild traumatic brain injuries, or concussions, are generally accompanied by a variety of somatic, cognitive and affective symptoms, including depressive-like symptoms. Although for most individuals, the affective symptoms are relatively transient, for others $(\sim$ 17 to $44 \%$ ), these symptoms can persist for extended periods of time. The longer-lasting symptomology appears to depend, in part, on gender, age, prior concussion history and symptom presentation. Accordingly, the purpose of the present study was to examine several cognitive, genetic, and experiential factors which might be associated with depressive pathology among males and females with and without a history of concussion. To this end, male and female university students, ranging in age from 17 to 25 , with a history of concussions $(n=105)$ and a control group of "never-concussed" individuals $(n=$ 214) completed the Wisconsin Card Sorting Task (WCST) to assess executive function as well as several questionnaires assessing cognitive vulnerabilities to depression, early life adversity, and depressive symptomatology. Participants also provided a saliva sample for DNA analysis. Among females, but not males, a history of prior concussions was associated with depressive symptoms, especially among individuals with reduced cognitive functioning as well as greater levels of dysfunctional attitudes and prior history of physical abuse. Furthermore, depressive symptoms were significantly elevated in Caucasian females who reported a concussion and possessed the heterozygous DRD2 C957T (rs6277) genotype compared to those that have not suffered a concussion. The present findings provide further insight into several factors that might contribute to long-lasting depressive pathology following a concussion and the significance of gender.
\end{abstract}




\section{Acknowledgments}

First and foremost, I would like to thank my supervisor, Dr. Matthew Holahan, for his tremendous support and leadership throughout my master's. I will always be grateful for having this opportunity to work with him and study something that I am passionate about. Thank you also to Dr. Hymie Anisman, who has provided me with great guidance, especially with introducing me to human research. I am also very thankful to my committee members, Dr. Kim Matheson, Dr. Shawn Hayley, and Dr. Renate Ysseldyk, for taking the time to share their valuable knowledge.

I am very grateful to the other graduate students in the department, particularly Rob Gabrys, for allowing me to be part of this project and providing me with fantastic direction. Without Rob, this project and the additional research with athletics would not have been possible. To the other PhD and Master students that I had the chance to work with: not only have we made great memories, but also I would have not have been able to complete this without you. With that, I must acknowledge Carleton University Athletics, particularly Nadine Smith and Dr. Taylor, not only for their assistance with my research, but especially their kindness.

Last, but most definitely not least, thank you to my friends and family. Dan, thank you for your love and patience, especially during the stressful moments. To my parents, thank you for providing me with so many opportunities and unconditional support throughout my life, which have allowed me to pursue my goals. 


\section{Table of Contents}

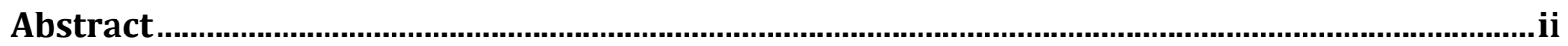

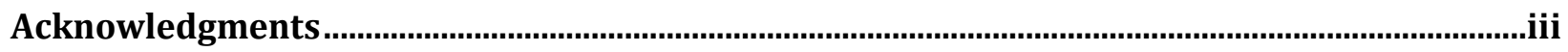

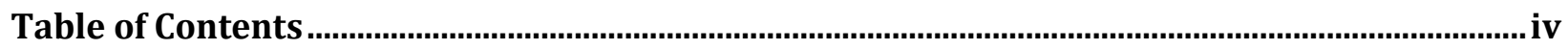

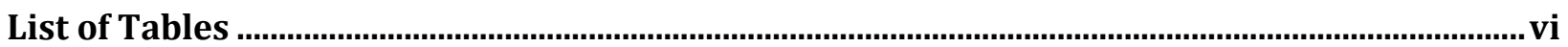

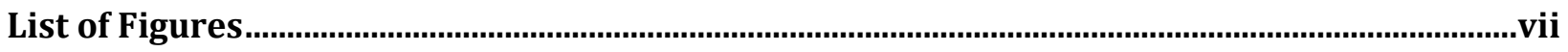

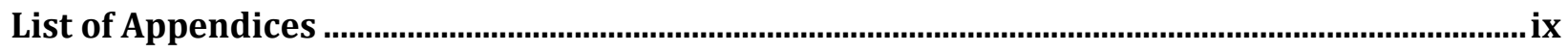

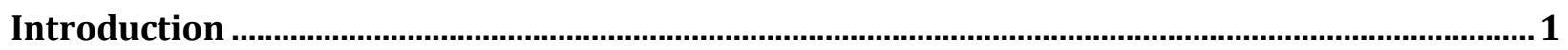

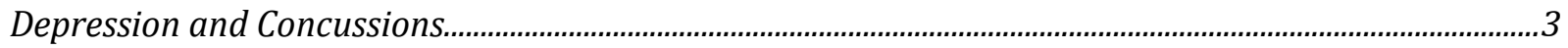

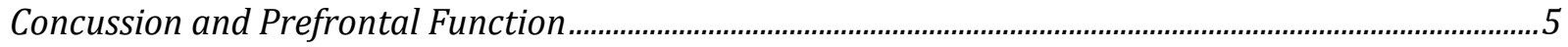

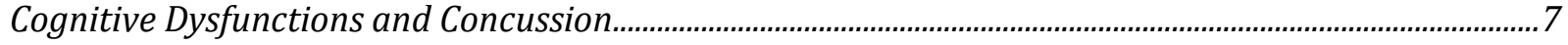

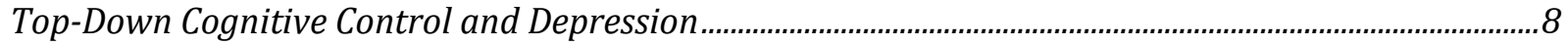

Cognitive Control, Depression and Concussion........................................................................................ 10

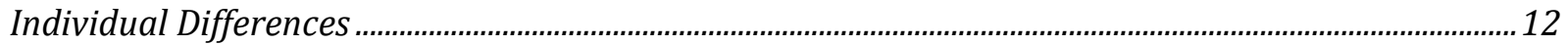

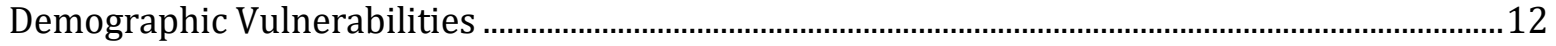

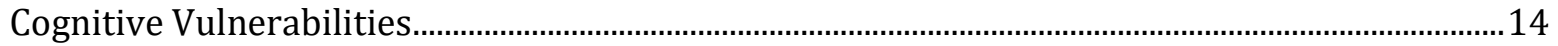

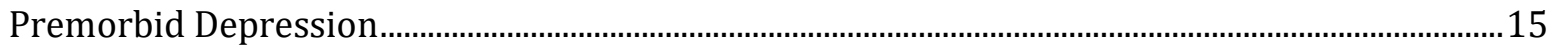

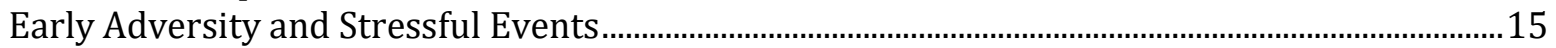

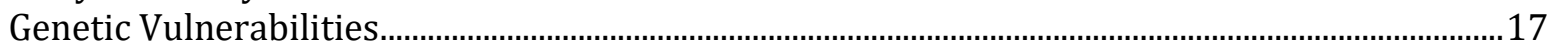

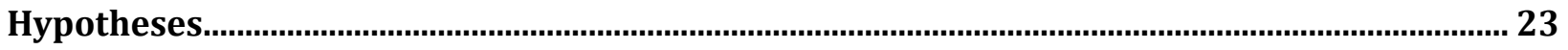

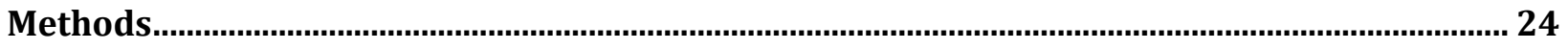

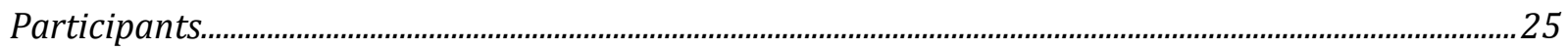

Procedure

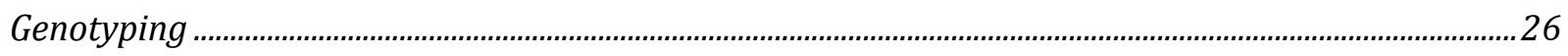

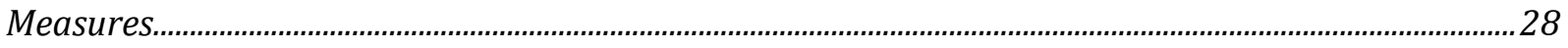

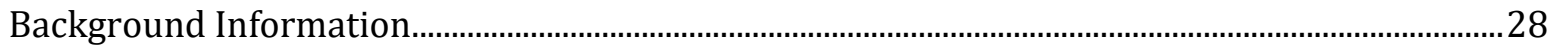

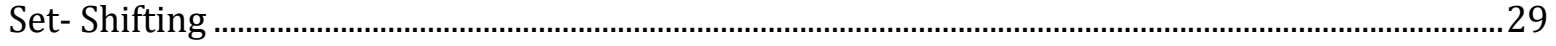

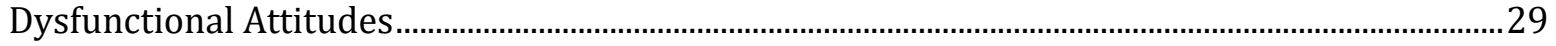

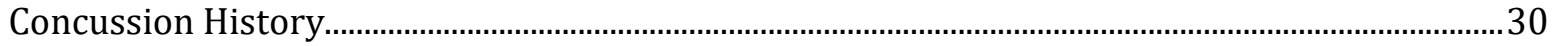

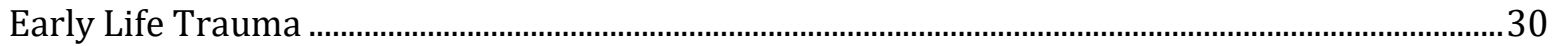

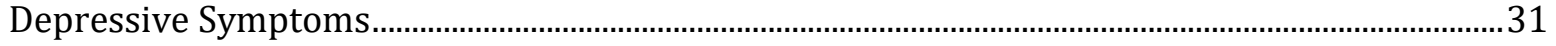

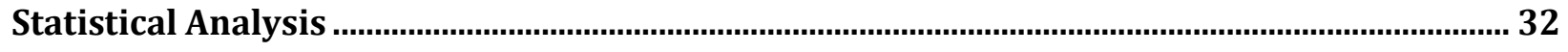

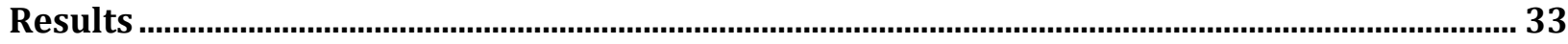

Experiential and Cognitive Contribution to Depressive Symptoms in Male and Female Students with

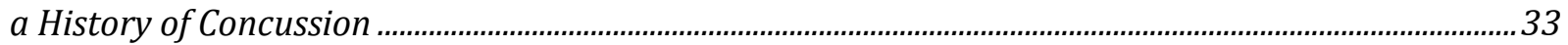

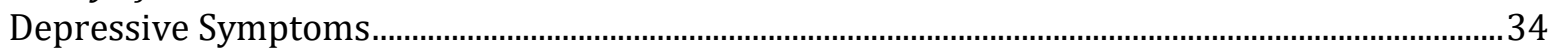

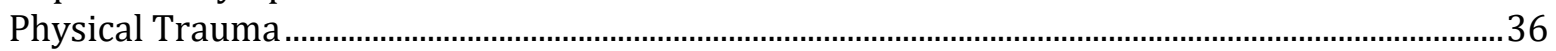

Physical Trauma Experienced During Different Ages...............................................................................39

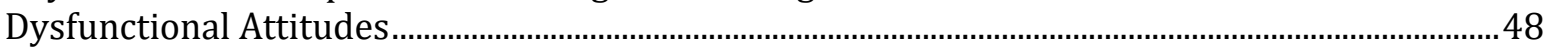

Perseverative Errors.......................................................................................................................................51

Genetic contribution to depressive symptoms in Caucasian male and female students with a history

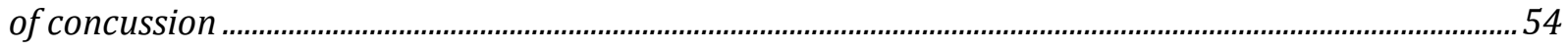

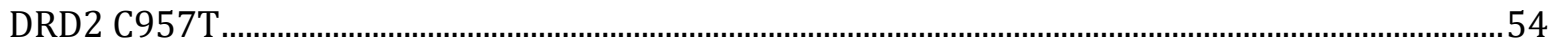


COMT val ${ }^{158}$ met

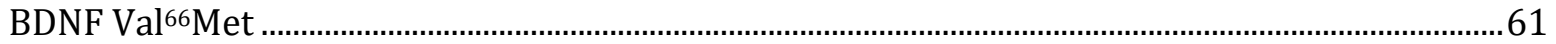

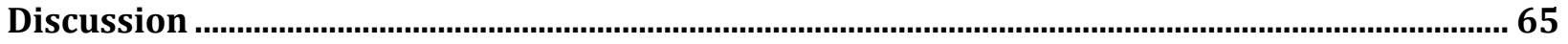

Experiential and Cognitive Contribution to Depressive Symptoms in Male and Female Students with

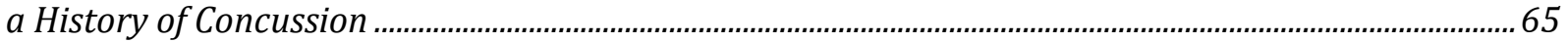

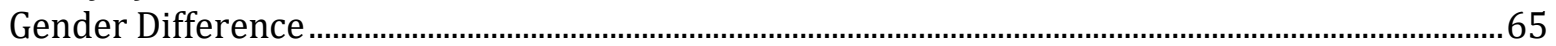

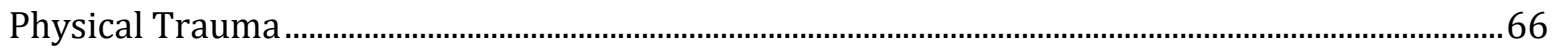

Physical Trauma Experienced During Different Ages..............................................................................68

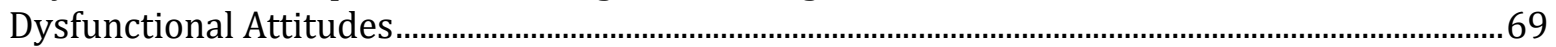

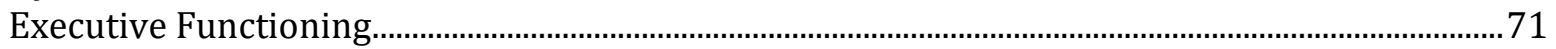

Genetic contribution to depressive symptoms in Caucasian male and female students with a history

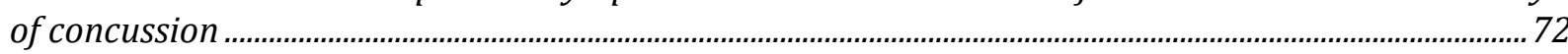

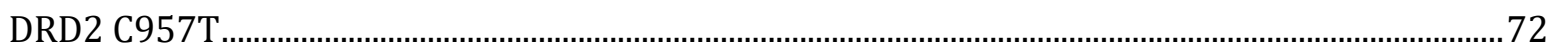

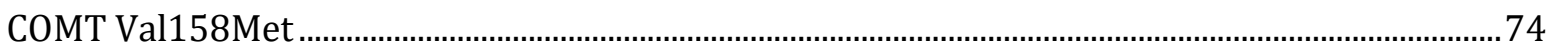

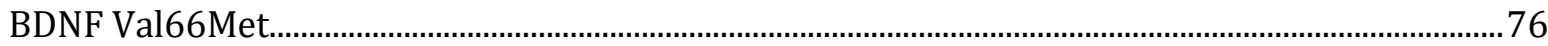

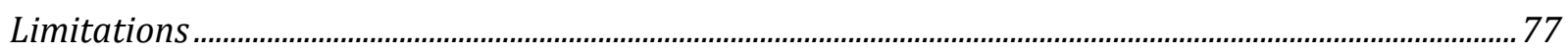

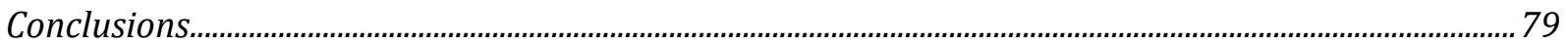

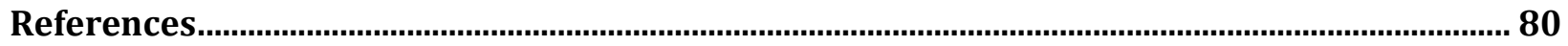

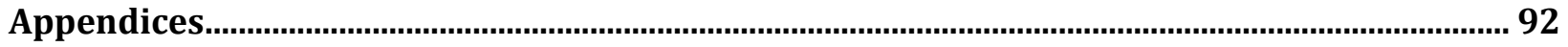




\section{List of Tables}

Table 1. Allele distributions for DRD2 polymorphisms..............................................................28

Table 2. Allele distributions for COMT polymorphisms .....................................................................28

Table 3. Allele distributions for BDNF polymorphisms...............................................................28

Table 4. Pearson Correlations depicting relations between physical trauma, dysfunctional

attitudes, perseverative errors, and depressive scores in females $(n=174)$.

Table 6. Mean depressive symptom scores by DRD2 C957T genotype for all females, females

with a concussion history, and females without a history of concussion.

Table 7. Mean depressive symptom scores by DRD2 C957T genotype for all males, males with a concussion history, and males without a history of concussion.

Table 8. Mean depressive symptom scores COMT Val158Met genotype for all females, females with a concussion history, and females without a history of concussion.

Table 9. Mean depressive symptom scores COMT Val158Met genotype for all males, males with a concussion history, and males without a history of concussion. 60

Table 10. Mean depressive symptom scores by BDNF Val66Met genotype for all females, females with a concussion history, and females without a history of concussion... 62

Table 11. Mean depressive symptom scores by BDNF Val66Met genotype for all males, males with a concussion history, and males without a history of concussion. 63 


\section{List of Figures}

Figure 1. Changes in depressive symptom score as a function of reported concussion incidence in females. 35

Figure 2. Changes in depressive symptom score as a function of reported concussion incidence in males... 36

Figure 3. The relation between total phsical trauma and depression scores as a function of concussive incidence in females.

Figure 4. The relation between total physical trauma and depression scores as a function of concussive incidence in males.

Figure 5. The relation between levels of physical trauma experienced between ages 0 and 5 and depression scores as a function of concussive incidence in females 40

Figure 6. The relation between levels of physical trauma experienced between ages 6 and 12 and depression scores as a function of concussive incidence in females.

Figure 7. The relation between levels of physical trauma experienced between ages 13 and 18 and depression scores as a function of concussive incidence in females 42

Figure 8. The relation between levels of physical trauma experienced after the age of 18 and depression scores as a function of concussive incidence in females.

Figure 9. The relation between levels of physical trauma experienced between ages 0 and 5 and depression scores as a function of concussive incidence in males

Figure 10. The relation between levels of physical trauma experienced between ages 6 and 12 and depression scores as a function of concussive incidence in males. 46

Figure 11. The relation between levels of physical trauma experienced between ages 13 and 18 and depression scores as a function of concussive incidence in males. 
Figure 12. The relation between levels of physical trauma experienced after age 18 and depression scores as a function of concussive incidence in males.

Figure 13. The relation between dysfunctional attitudes and depression scores as a function of concussive injury in females. 50

Figure 14. The relation between dysfunctional attitudes and depression scores as a function of concussive injury in males. 51

Figure 15. The relation between perseverative errors and depressive symptom scores as a function of concussive injury in females.

Figure 16. The relation between perseverative errors and depressive symptom scores as a function of concussive injury in males.

Figure 17. Changes in depressive symptom score as a function of reported concussion incidence and DRD2 C957T genotype in females

Figure 18. Changes in depressive symptom score as a function of reported concussion incidence and DRD2 C957T genotype in males

Figure 19. Changes in depressive symptom score as a function of reported concussion incidence and COMT val158me genotype in females.

Figure 20. Changes in depressive symptom score as a function of reported concussion incidence and COMT Val158Met genotype in males.

Figure 21. Changes in depressive symptom score as a function of reported concussion incidence and BDNF Val ${ }^{66}$ Met genotype in females. 62

Figure 22. Changes in depressive symptom score as a function of reported concussion incidence and BDNF Val66Met genotype in males. 64 


\section{List of Appendices}

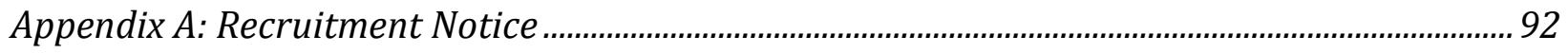

Appendix B: Informed Consent

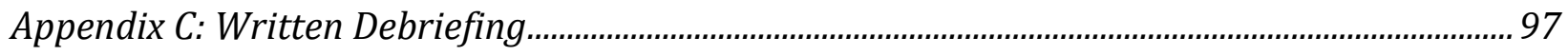

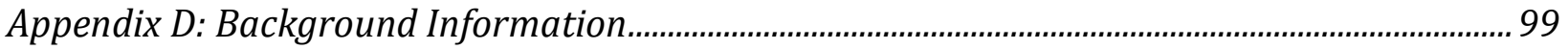

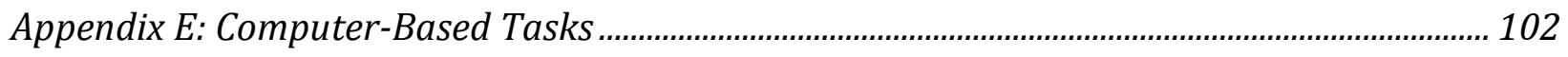

Appendix F: Dysfunctional Attitudes Scale- Short Form ............................................................... 103

Appendix G: Mild Traumatic Brain Injury................................................................................. 104

Appendix H: Early Life Trauma- Short Report................................................................................ 106

Appendix I: Beck Depression Inventory .................................................................................. 113

Appendix J: Additional Computer Tasks......................................................................................... 116

Appendix K: Additional Measures ......................................................................................... 117 


\section{Introduction}

The estimated annual worldwide incidence of concussion is 42 million with the majority resulting from motor vehicle accidents, contact sports, military combat, domestic violence and falls. Although most concussions are considered mild, with symptoms that subside within three months following injury, approximately 10 to $20 \%$ of concussed individuals have long lasting (longer than 3 months) symptoms (Ponsford et al., 2000, 2012).Those who show persistent symptoms (i.e., longer than 3 months), such as headaches, fatigue, difficulty concentrating, dizziness, memory dysfunction, frustration, anxiety, trouble sleeping, irritability, and depression, are considered to be suffering from "post-concussion syndrome” (PCS) (Broshek et al., 2015). The presence of any combination of these symptoms is detrimental to the success of everyday tasks, not to mention the negative impact on work, academics, and participation in sports. Considering the enormous global prevalence of concussion and the number of individuals who continue to experience persistent symptoms, it is not surprising that concussions are thought of as a "silent epidemic" (Moore et al., 2013).

Concussions are often classified as functional (as opposed to structural) brain injuries caused by either direct or indirect blows to the head or body that result in a rapid acceleration and deceleration of the brain (Signoretti et al., 2011). This rapid brain movement can result in a myriad of symptoms such as confusion, loss of consciousness, and memory loss (Gardner and Yaffe, 2015). The explanation of why some individuals have long-lasting symptoms (e.g. depression) after concussion and others do not is not completely understood. Many studies have examined predictors of mood disorders after 
concussion, finding that people are more susceptible if they have experienced pre-injury anxiety, depression, life stressors, or possess certain coping styles (Ponsford et al., 2012; Broshek et al., 2015). These predictors are associated with deficits in cognitive function, which have been shown to play a major role in the onset and persistence of depressive mood in those with certain vulnerabilities (Disner et al., 2011). For example, someone who is susceptible to cognitive deficits, whether it is through coping styles or genetic traits, could be at an increased risk for depressive symptoms following concussion.

Given these links, the present investigation examined (1) the relationship of previous concussion history and executive function with depressive symptoms, (2) predictors of depressive symptoms and executive function following concussion, and (3) the relationship between genetic polymorphisms, depressive symptoms, and executive functions in those reporting concussions.

\section{Neural Metabolic Cascade and Neural Inflammation after Concussion}

When a concussion occurs, rotational forces cause stretching and shearing of neural tissue, triggering a neurometabolic cascade (Giza and Hovda, 2001). Briefly, this cascade involves the release of excitatory neurotransmitters and ions, which disturb the production of adenosine triphosphate (ATP). This causes an increased energy demand as the brain strives to restore equilibrium through ion pumps. Since ATP production is impaired during this time of stress, there is a resulting energy deficit (Giza and Hovda, 2001). This energy deficit is apparent in humans, where a decrease in global cerebral glucose metabolism has been seen for several weeks after injury (Bergsneider et al., 2000). In fact, the majority of symptoms immediately following a concussion have been attributed to the energy deficit that this cascade manifests (Giza and Hovda, 2001). Furthermore, as the brain is already 
energy deficient, additional stressors may lead to further injuries, as the brain is unable to keep up with the demand.

Concussive injuries additionally trigger an inflammatory response that can be both neuroprotective and neurotoxic (Patterson and Holahan, 2012). For example, cytokines,

like interleukin-1 (IL-1), are upregulated following a concussion (Fan et al., 1995; Winter et al., 2002). IL-1 $\beta$ works to defend against cell death by promoting the secretion of nerve growth factors (Patterson and Holahan, 2012). However, the levels of IL-1 $\beta$ are suggested to be elevated for a prolonged time after concussion, at which point IL-1 $\beta$ may become neurotoxic, contributing to cell death (Clausen et al., 2011). Along with IL-1 cytokines, the inflammatory response following concussion involves tumor necrosis factor- $\alpha$ (TNF- $\alpha$ ), interleukin-6 (IL-6), transforming growth factor- $\beta$ (TGF- $\beta$ ), and interleukin-10 (IL-10), all of which have been shown to be both beneficial and detrimental to the brain, depending on when and the length of time they are active post-concussion (Patterson and Holahan, 2012). Overall, neural inflammation may be an important factor in producing structural and functional changes in the brain following concussions, which may contribute to the development of long term-symptoms, such as depression.

\section{Depression and Concussions}

Depressive symptoms are often reported both immediately and for some time after (i.e., long-term) by individuals who have experienced a concussion at some point in their life (Rutherford et al., 1977; Broshek et al., 2015; Solomon et al., 2015). Rutherford et al (1977) were the first to report depressive symptoms in a sample group of concussed individuals with approximately $6 \%$ showing depressive symptoms at 6 weeks post injury. 
Other studies have shown varying incidence of depressive symptoms in concussed populations from $34 \%$ at approximately 1 month post injury to between 17 and $44 \%$ at three months (Goldstein et al., 2001; Levin et al., 2001; McCauley et al., 2001; Mooney and Speed, 2001). Overall, depressive symptoms are consistently seen as a long-lasting deficit following concussion and may be a key indicator of persistent underlying neural dysfunctions.

Vargas and colleagues (2015) measured depressive symptoms following concussion in a sample of undergraduate student athletes. They reported that, compared to a baseline measure of depression, depressive symptoms increased in 17 of 85 (20\%) concussed athletes and only 2 of 42 (4\%) control athletes (Vargas et al., 2015). The rate of depressive symptoms after concussion appears to be associated with the number of concussive impacts (Broshek et al., 2015). For instance, Guskiewicz and colleagues (2007) examined the relation between clinical depression diagnosis and concussive injuries in 2552 retired National Football League (NFL) players. Those who reported sustaining more than three concussions were three times more likely to be diagnosed with clinical depression, compared to 1.5 times in those reporting one or two concussions (Guskiewicz et al., 2007). In another study, retired varsity athletes who sustained three or more concussions were found to have 2.5 times the prevalence of depressive symptoms compared to nonconcussed athletes (Kerr et al., 2014). Though the cause is still not clear, depressive symptoms following concussion are hypothesized to arise from damage within the frontolimbic structures of the brain including the pre-frontal cortex (PFC) (McCrory et al., 2013). 


\section{$\underline{\text { Concussion and Prefrontal Function }}$}

Unlike some brain structures that are quite stable after development, the PFC is highly plastic throughout the lifespan which makes it especially vulnerable to injury (McEwen and Morrison, 2013). This is particularly true in young people as the critical period of human PFC development lasts into adolescence (Kolb et al., 2012). Similarly, the aged brain has been shown to be especially vulnerable, potentially because of loss of synapses on PFC pyramidal neurons (Dumitriu et al., 2010; McEwen and Morrison, 2013). Considering the vulnerability of the PFC, it is not surprising that this region seems to be one of the first areas that is affected by concussive brain injuries (Broshek et al., 2015).

One of the main functions associated with the PFC is executive function, which includes higher order cognitive abilities that allow appropriate problem solving (Stuss, 2011; Funahashi and Andreau, 2013; Logue and Gould, 2014). This encompasses a wide range of functions, including planning, decision-making, working memory, attention, and set shifting (Funahashi and Andreau, 2013). The vital role of the PFC in executive function is clear when examining patients with damage to their frontal lobe, termed "frontal lobe syndrome" (Funahashi and Andreau, 2013). These patients seem to have a lack of judgement, working memory, and planning while they are able to retain their long-term memory, language skills, and motor capabilities (Stuss and Benson, 1984). In addition to executive function, the PFC also has an important role in maintaining a "balance" in subcortical function via inputs to areas including the hippocampus, amygdala, and thalamus (McEwen and Morrison, 2013).

Deficits in judgement, working memory, and planning are seen in patients who have experienced multiple concussions and were diagnosed with chronic traumatic 
encephalopathy (CTE) (Stein et al., 2015). Studies assessing retired athletes who endured multiple concussions and developed CTE provide evidence that these cognitive deficits arise, at least in part, from damage to the PFC (Stein et al., 2015). Not only is the first stage of CTE characterized by the accumulation of tau protein (a biomarker widely associated with dysfunction) within the PFC, but disrupted PFC functions are also shown behaviourally as CTE is manifest by various cognitive impairments. Concentration issues, mood impairments (e.g. depression), and motor dysfunction are some of the impairments associated with the first stage of CTE (Stein et al., 2015).

The function of the PFC following concussion appears to be negatively impacted even though structural brain imaging, such as magnetic resonance imaging (MRI), following concussion does not generally show structural damage (Dettwiler et al., 2014; Stein et al., 2015). A functional MRI (fMRI) study examining blood oxygen level dependent (BOLD) activity after concussion showed significant hyperactivity in both hemispheres of the dorsolateral prefrontal cortex (DLPFC) while subjects performed a working memory task at two weeks and eight weeks after concussion (Dettwiler et al., 2014). Activity in the left inferior parietal area was also significantly increased compared to controls up to two weeks post concussion. Other studies have revealed similar BOLD response abnormalities during a working memory task performed within one week after a concussion, finding increased BOLD activity in the inferior parietal regions of concussed male undergraduate athletes (Jantzen et al., 2004), and increased BOLD activity in the right DLPFC in a mixed sex sample of undergraduate athletes (Slobounov et al., 2010). Overall, compared to controls, findings suggest that activity in the PFC following concussion is significantly altered in concussed individuals performing various cognitive tasks. 


\section{Cognitive Dysfunctions and Concussion}

Considering the functions associated with the PFC and the evidence indicating that the PFC may be damaged after concussion, it is not surprising that there are general deficits in executive functioning (cognitive control) in those who have suffered a concussion. Ellemberg et al (2007) assessed cognitive control in university level female soccer players and found that concussed athletes displayed many deficits compared to non-concussed team mates, including lowered inhibition speed, flexibility speed, and response time on computer tasks (Ellemberg et al., 2007). These results suggest that concussed athletes, particularly females, have particular deficits in processing speed. Similarly, Pontifex and colleagues (2012) reported that university athletes with a history of sports related concussion (SRC) had reduced ability to sustain attention compared to controls. Additionally, the number of errors made on an attention task was positively correlated with the number of reported concussions (Pontifex et al., 2012).

Long-term cognitive control deficits have also been linked to differences in event related potentials (electro-encephalography (EEG) measured brain responses to an event or task) in people who sustained a sports related concussion (SRC) in adolescence and were tested in adulthood (Moore et al., 2013). In this study, subjects were tested approximately 7 years after injury and, compared to controls, had decreased response accuracy on an inhibition task, longer reaction times, and reduced accuracy on a switch task that required the participant to remember multiple rules. Furthermore, compared to controls, previously concussed participants had many deficits in neurocognitive function associated with attentional resource allocation and task switching, particularly in tasks with multiple rules (Moore et al., 2013). These deficits indicate that cognitive flexibility, 
working memory, and attention were diminished for the long-term in those who experienced a concussion as an adolescent.

Interestingly, Sterr et al (2006) noted that deficits in cognitive function were only significant in those who had suffered a concussion and were still reporting PCS.

Participants who were still reporting PCS, such as depression, at least one year after injury reported significantly more cognitive failures on everyday tasks and more cognitive errors on computer tasks compared to healthy controls and a group of concussed participants not reporting PCS. Another study reported that executive function deficits were related to those still reporting PCS, including self-reported mood and cognitive issues, one year later, compared to those whose PCS diminished (Barker-Collo et al., 2015).

\section{Top-Down Cognitive Control and Depression}

Efficient cognitive control relies on top-down regulation of limbic regions by the PFC (Disner et al., 2011). Different aspects of cognitive control, such as attention, inhibition, and working memory have been associated with region specific control of lower limbic regions. In healthy individuals, top-down attention is associated with the superior temporal sulcus, intraparietal sulcus, precentral sulcus and certain areas of the PFC (Corbetta et al., 1998). These regions coordinate their functions, allowing the individual to attend to relevant stimuli while inhibiting processing of irrelevant stimuli (Kastner et al., 1998). In order to have effective attentional control, it is important to be able to switch focus to relevant stimuli and disengage from unnecessary stimuli. For this to occur efficiently, the ventro-lateral PFC (VLPFC) is required to select the important stimulus, the superior parietal cortex is required to shift the visual perspective to the important cue and the dorso-lateral PFC (DLPFC) is required to recruit other executive functions (e.g. 
inhibition) (Disner et al., 2011). Ignoring irrelevant stimuli also contributes to successful attention to appropriate cues specific to a given situation. In healthy individuals, ignoring positive stimuli is associated with an increase in rostral anterior cingulate cortex (ACC) activity (Bush et al., 2000; Shafritz et al., 2006; Eugène et al., 2010). The ACC has inhibitory projections to the VLPFC to promote disengagement of those stimuli (Disner et al., 2011). Efficient cognitive control also requires that information be temporarily stored, controlled, and manipulated in order to complete a task (Baddeley, 2003). The DLPFC is employed in working memory tasks, most likely contributing to determination of taskrelevant information and revising the task based on changing rules and responses (Brunoni and Vanderhasselt, 2014). The left inferior frontal gyrus and ACC are other regions recruited when one is performing a working memory task (Braver et al., 1997)

Dysfunction in areas involved in attention, inhibition, and working memory can lead to an imbalance and the favouring of bottom-up control by the limbic system, particularly the amygdala (Disner et al., 2011). Bottom-up control of the PFC is modulated through the subgenual cingulate cortex, ACC, caudate, putamen, hippocampus and nucleus accumbens. Hyperactivity in these regions, along with hypoactivity in the PFC, is associated with biased attention to negative stimuli, decreased attention to positive stimuli, biased memory to negative events and dysfunctional attitudes (Disner et al., 2011).

In depressed individuals, attentional coordination is reduced, resulting in an inability to disengage from irrelevant stimuli and attend to relevant stimuli (Goeleven et al., 2006; Joormann et al., 2007). Mitterschiffthaler and colleagues (2008) reported that depressed individuals had a significant increase in activity of the rostral ACC when asked to inhibit attention to negative stimuli compared to neutral stimuli. The healthy controls did 
not show an increase in rostral ACC activity when inhibiting attention to negative stimuli, suggesting that less effort was needed to disengage from negative stimuli (Mitterschiffthaler et al., 2008).

Deficits in working memory are also associated with depression and changes in topdown control (Wang et al., 2015). Individuals with depression often report deficits in memory in addition to an inability in organizing and planning successive tasks. Although deficits in working memory related with major depression disorder (MDD) are associated with changes in the DLPFC, both hyper- and hypoactivity have been reported (Matsuo et al., 2007; Pu et al., 2011). Hyperactivity in the ACC was reported while MDD patients performed a working memory task, though in this instance, task performance was similar to controls (Matsuo et al., 2007). Differential activation may represent different compensatory strategies for performing working memory tasks, such as recruiting more resources for processing, or might represent the level of demand the specific task imposes (Pu et al., 2011; Wang et al., 2015).

These studies indicate the possibility that depressed individuals have difficulty in ignoring negative stimuli, attending to relevant stimuli, and an inability to complete consecutive tasks (Shafritz et al., 2006; Mitterschiffthaler et al., 2008; Disner et al., 2011). Thus, individuals with dysfunctional cognitive control have difficulty completing everyday tasks, and are repeatedly exposed to negative content, leading to the development and maintenance of depressive symptoms (Disner et al., 2011).

\section{Cognitive Control, Depression and Concussion}

As discussed previously, depression is commonly reported for a prolonged period following concussion, along with other cognitive disturbances. These two features of PCS 
may be related, with the depressive symptoms developing due to the underlying pathophysiology of concussion (Chen et al., 2008a). Specifically, damage to the PFC may lead to the dysfunctions in cognitive control after concussion, which could contribute to improper information processing and result in depressive symptoms (Disner et al., 2011).

Chen and colleagues (2008) conducted an imaging study to assess the neural correlates of depressive symptoms in concussed male athletes with no prior history of mood disorders. The participants were asked to complete a working memory task 5 to 7 months after injury. In their study, the concussed individuals reporting mild and moderate depressive symptoms were grouped separately from those without depressive symptoms, and both groups were compared to control athletes (Chen et al., 2008a). Control athletes had increased BOLD activation of the right DLPFC, striatum, and thalamus compared to participants with depressive symptoms. A decrease in activation was seen in subjects with moderate depressive symptoms compared to those subjects reporting mild symptoms. Similar BOLD activation was reported in the rostral ACC, medial orbital frontal cortex (mOFC), posterior cingulate cortex, and parahippocampal gyrus (Chen et al., 2008a). Using voxel-based morphometry, Chen et al (2008) showed that participants reporting depression following a history of concussion had reduced gray matter density in the medial frontal regions, temporal regions, and rostral ACC; regions associated with working memory. In comparison, only the insular cortex showed reduced gray matter in the group who were concussed with no depressive symptoms. Thus, Chen et al (2008) provided evidence that the depressive symptoms following concussion are indications of neural pathologies, particularly in the frontal cortex, resulting from concussion. 


\section{$\underline{\text { Individual Differences }}$}

It is clear that depression and diminished cognitive control are prevalent in individuals who have experienced a concussion. However, not every concussive injury results in depressive symptoms or issues in cognition, especially in the long-term (Ponsford et al., 2000, 2012). Interestingly, the severity of injury does not seem to predict long-term PCS (Vargas et al., 2015). It is possible that premorbid factors contribute to PCS susceptibility, making certain individuals more vulnerable than others (Broshek et al., 2015). Multiple studies have been conducted in an attempt to find predictors of increased short-term symptoms after injury as well as long-term PCS (Ponsford et al., 2000, 2012; McCauley et al., 2013; Olsson et al., 2013; Ganti et al., 2014; Merritt and Arnett, 2014; Vargas et al., 2015). These studies have reported mixed results, finding predictors such as sex, age, cognition, early life stress, premorbid depression, and genetics. The following sections will review possible vulnerabilities to long-term depressive symptoms after concussion.

\section{Demographic Vulnerabilities}

Studies assessing demographic variables, such as age and sex, as predictors of longterm PCS have revealed mixed results (Dougan et al., 2014). A meta-analysis looking at a total of 3801 concussed and 5631 control athletes found that females show more neuropsychological deficits after concussion than males, and adolescents showed more post-concussive symptoms than adults (Dougan et al., 2014). Another study reported a similar relationship for age and sex, with concussed female athletes and high school student athletes performing worse on a visual memory test than concussed male and college athletes (Covassin et al., 2012). However, Dougan et al (2014) found that male 
athletes were more likely to report symptoms after concussion than females and other studies have reported older age (i.e. 36 years old) as a vulnerability factor for persistent symptoms after concussion (King, 2014). Unfortunately, the majority of results reported in these studies only assessed athletes up to two weeks post-concussion and therefore, the reported symptoms cannot be considered PCS. Another issue with these results is the lack of data in concussed females, making comparisons between sexes difficult (Dougan et al., 2014).

Differences in brain structure and function between sexes and at different points of development could underlie individual differences in PCS (Dougan et al., 2014). One difference could be introduced by metabolic demand and the degree of metabolic cascade following concussion (Broshek et al., 2005). Females tend to have a higher metabolic demand, and they could have an intensified metabolic cascade following concussive injury (Andreason et al., 1994; Giza and Hovda, 2001; Broshek et al., 2005). If this were the case, initial symptoms after concussion could be exacerbated in females and long-term damage would be more probable. Additionally, depression, which is considered a symptom of PCS, has a higher prevalence in females in the general population (Ferrari et al., 2013). Taking into account literature alluding to premorbid depression as a predictor of depression in PCS (to be discussed in a later section), females may be more vulnerable (Vargas et al., 2015).

As discussed previously, the PFC in particular is likely to be damaged after concussion and this damage is associated with post-concussion symptoms such as deficient executive function. The PFC continues to develop into adolescence and thus it is not surprising that the age of an individual at time of concussion could be a vulnerability factor 
for PCS (Kolb et al., 2012). Furthermore, considering the aged brain is also vulnerable to injury, a concussion sustained at an older age may also constitute an increased risk for PCS (McEwen and Morrison, 2013). This vulnerability may explain the increased PCS in older individuals as reported by King (2014).

\section{Cognitive Vulnerabilities}

Deficits in cognitive control and depressive symptoms are seen in individuals suffering from PCS in addition to abnormalities in top-down functioning by the PFC. Consequently, certain cognitive attributes, such as negative cognitive style and dysfunctional attitudes, may predispose someone to heightened cognitive deficits and ensuing depression after concussion.

Dysfunctional attitudes are defined as negative, maladaptive schemas that become apparent after exposure to a stressful life event, and have been considered to be a cognitive vulnerability factor to depression (Beck, 1967; Teasdale, 1988; de Graaf et al., 2009). You and colleagues (2009) found that dysfunctional attitudes moderated the relationship between lifetime stress and depressive symptoms in female participants. It is hypothesized that once dysfunctional attitudes are activated by a negative event, it is more likely that the individual will be unable to disengage attention from negative stimuli resulting in exacerbation of depressive symptoms (Disner et al., 2011). This suggests that individuals with dysfunctional attitudes have poor cognitive control. Therefore, if someone possesses dysfunctional attitudes, previous deficits in cognition could be worsened by a concussive injury. A concussion may also act as a stressor that activates latent dysfunctional attitudes, increasing over-attention on negative thoughts (Disner et al., 2011). In summary, someone 
who possesses dysfunctional attitudes or latent negative schemas may be particularly vulnerable to post-concussion depression.

\section{Premorbid Depression}

Pre-injury psychiatric disorders have also been associated with an increased vulnerability to negative outcomes after concussion, particularly depression and anxiety (Ponsford et al., 2012). Vargas et al (2015) noted that baseline depressive symptom scores were reliable predictors of post-concussion depression in athletes. The increase in depressive symptoms after concussion in those with premorbid depression may be the result of many factors, including coping with the injury and symptoms, decreased participation in sport, or physiological changes (Vargas et al., 2015). Since prefrontal damage and deficits in cognitive control are seen in depressed individuals, a concussion could cause further damage and deficits, leading to long-term post-concussion depression.

\section{Early Adversity and Stressful Events}

Individuals who have experienced stressful life events, including childhood maltreatment, have an increased incidence of depression and deficits in executive function (Kendler et al., 1999; Shonkoff and Garner, 2012). Zhao and colleagues (2015) reported that adults who disclosed a history of childhood maltreatment (i.e. before age 18) displayed impairments in tasks that rely on frontal and temporal brain areas. Furthermore, females with schizophrenia who reported experiencing childhood physical trauma had significantly more depressive and psychotic symptoms compared to males and females without a history of physical abuse (Kelly et al., 2016). So far, only one study has evaluated the influence of early adversity on post-concussive outcome. van Veldhoven et al (2011) 
assessed the influence of stressful life events on the outcome of concussion 3 months after injury. It was found that stressful life events, such as physical or sexual assault, were predictive of negative outcomes, including depression and anxiety, 3 months after concussion (van Veldhoven et al., 2011; Ponsford et al., 2012).

In a healthy individual, stress activates the hypothalamus-pituitary-adrenal (HPA) axis to release corticotropin-releasing hormone (CRH) from the hypothalamus (Lupien et al., 2009). CRH then stimulates the pituitary to secrete adrenocorticotropic hormone (ACTH), which travels to the adrenal cortex to trigger the release of glucocorticoids (cortisol in humans). After the stressor, glucocorticoids bind to glucocorticoid and mineralocorticoid receptors in the hypothalamus, adrenal gland, hippocampus, and frontal cortex in a negative feedback loop to obtain homeostasis.

Childhood adversity, such as emotional, physical, and sexual abuse, is a stressor that activates the HPA axis (Lupien et al., 2009). The elevated levels of glucocorticoids can be damaging, especially to structures undergoing development at the time of stress. Physiological changes of the frontal cortex, including reduced grey matter volume, and overall reduction in ACC volume, have been reported in adolescents who were exposed to stressors in childhood (Cohen et al., 2006; Lupien et al., 2009). In contrast, dendritic arborization of the amygdala has been shown to increase under chronic stress (Lupien et al., 2009). Overall, childhood adversity may influence the ability of the PFC to maintain a "balance" in subcortical function, increasing vulnerability to later depression (McEwen and Morrison, 2013). This vulnerability may be especially pronounced in females as studies suggest they have greater HPA axis reactivity to stressors (Goel et al., 2014), such as prolonged exposure to heat or cold (Gerra et al., 1992; Jezová et al., 1994). Therefore, if the 
PFC is already adversely affected by a stressful event, concussive injury may exacerbate the abnormalities that are already present, especially in females.

\section{Genetic Vulnerabilities}

Certain genetic profiles have been hypothesized to modulate the development of depression in the general population, mainly through interactions with stressful life events and/or cognitive vulnerabilities (Hankin et al., 2009). It is possible that genetic vulnerabilities to depression could also mediate susceptibilities to post-concussion depression, especially if they are associated with cognitive processing. The following section will discuss polymorphisms that have been associated with vulnerability to cognitive deficits and depression, along with evidence to support a role for these polymorphisms in a risk to long-term depression in PCS.

Brain Derived Neurotrophic Factor Val ${ }^{66}$ Met Polymorphism

Brain derived neurotrophic factor (BDNF) is one of the most abundant neurotrophins in the brain, associated with synaptic plasticity and necessary in the mature brain to maintain dendritic density and structural integrity of neurons (Hofer et al., 1990; Wetmore et al., 1990; Ghosh et al., 1994; Murer et al., 2001; Lamb et al., 2014). The BDNF Val66Met polymorphism (rs6265), where adenosine (A) is substituted for guanine (G) at codon 66 leading to the valine (Val) being substituted by methionine (Met), is associated with less BDNF secretion and differences in brain function and structure (Pezawas et al., 2004; Lamb et al., 2014). It has been shown that Met allele carriers have a reduced cortical thickness in the frontal lobe and ACC compared to Val allele carriers, and that the difference is more drastic in those diagnosed with MDD (Legge et al., 2015) 
The presence of a Met allele is associated with an increased risk for developing depression, although this finding is inconsistent (Egan et al., 2003; Verhagen et al., 2010). When taking the breadth of literature as a whole, meta-analyses were unable to directly link the presence of a Met allele with an increased risk for developing depression (Verhagen et al., 2010; Hosang et al., 2014). However, there does seem to be an interaction with environmental events, specifically stressful life events, and the BDNF Val ${ }^{66} \mathrm{Met}$ polymorphism in predicting the development of depression (Gatt et al., 2009; Hosang et al., 2014; Harrisberger et al., 2015).

McAllister and colleagues (2012) looked at the presence of several BDNF single nucleotide polymorphisms (SNPs), including the Val66 Met allele, and executive function in concussed patients admitted to a hospital emergency centre. At one month postconcussion, reduced processing speed was associated with the presence of the Met allele, especially in male participants (McAllister et al., 2012). There was no association between cognitive function and the BDNF Val66Met polymorphism at one year follow up, although other BDNF SNPs were associated with memory deficits. The reduced cognitive functioning may be due to differences in brain structure and/or neuronal survival after injury in individuals with the $B D N F$ Val ${ }^{66}$ Met polymorphism, making the brain more vulnerable to injury and less able to recover. Therefore, the $B D N F$ Val ${ }^{66}$ Met polymorphism is a likely candidate for increased vulnerability to depression after a concussion. Catechol-o-methyltransferase Val158Met Polymorphism Catechol-o-methyltransferase (COMT) is the main regulator of dopaminergic synaptic transmission as it is an enzyme responsible for degrading dopamine (DA) (Axelrod and Tomchick, 1958; Winkler et al., 2015). Dopaminergic synaptic transmission is 
important for regulating cognition as low levels of DA within the PFC have been associated with deficits in executive function (Logue and Gould, 2014). Levels of DA can be regulated through the COMT Val ${ }^{158}$ Met polymorphism (rs4680), where substitution of A (Met) for G (Val) at codon 158 is associated with decreased COMT activity in the PFC (Lachman et al., 1996; Chen et al., 2004). Incidentally, the possession of a Met allele is associated with increased levels of catecholamines, particularly DA, in the PFC and better executive function (Tunbridge et al., 2004; Willmott et al., 2014).

The COMT Val158Met polymorphism has been assessed with regards to susceptibility to developing depression (Opmeer et al., 2010). Activity of COMT has been associated with depression severity, with symptoms decreasing in individuals given tolcapone, a COMT inhibitor (Fava et al., 1999). However, it is unlikely that there is a direct relationship between the COMT Val ${ }^{158} \mathrm{Met}$ polymorphism and depression considering mixed evidence (Opmeer et al., 2010). The relationship between the COMT Val ${ }^{158} \mathrm{Met}$ polymorphism and depression may be similar to the BDNF Val66Met polymorphism, with a gene environment interaction predicting depression (Mandelli et al., 2007). Interestingly, Mandelli and colleagues (2007) found that the Met substitution was associated with an increased stress response after an unpleasant life event. This finding may be attributable to the association between the $\mathrm{Met}^{158}$ substitution and increased limbic activation to aversive stimuli (Smolka et al., 2005).

Winkler and colleagues (2015) recruited individuals who sustained a concussion to investigate the presence of the COMT Val158Met polymorphism and cognitive symptoms 6 months after injury. Using various measures of cognitive function, their results revealed that individuals with a COMT Met ${ }^{158}$ allele had a significantly higher processing speed and 
the difference was associated with concussion injury severity (Winkler et al., 2015). Unfortunately, this study did not use a non-injured control group and therefore it is difficult to assess whether the presence of the COMT Val158Met polymorphism is associated with better recovery after concussion.

Dopamine D2 Receptor Polymorphisms

The DA D2 receptor (DRD2) is a receptor that binds DA and leads to an inhibitory response through G-proteins (Whitmer and Gotlib, 2012). Dopamine binding to this receptor is thought to contribute to a variety of behavioural operations including cognition, specifically inhibition of response tendencies (Hirvonen et al., 2009a; Whitmer and Gotlib, 2012). The DRD2 gene has multiple polymorphisms that influence its expression and as a result, dopaminergic action (McAllister et al., 2005). Considering the long-term deficits in cognitive control after concussion, combined with associations between DRD2 in cognition and DA transmission in executive functioning, it is not surprising that polymorphism within the DRD2 have been studied with respect to concussive outcomes. Taq1 A

One common polymorphism associated with the DRD2 gene is Taq1 A (rs1800497), a cytosine (C)/thymine (T) SNP (McAllister et al., 2005). The T allele is associated with an approximate $40 \%$ reduction in the concentration of DRD2s in the striatum, along with diminished executive function (Thompson et al., 1997; McAllister et al., 2008). In 2005, McAllister and colleagues assessed cognitive performance (i.e. processing speed) and the presence of the $\mathrm{T}$ allele after concussive injury. The results revealed a significant association between the $\mathrm{T}$ allele and poor response latency. The concussed participants in this study with the $\mathrm{T}$ allele, and as a result less DRD2, had greater cognitive deficits 
compared to healthy controls and concussed participants without the T allele. This suggests that individuals with the Taq1 A polymorphism of the DRD2 may be at an increased risk for cognitive deficits after concussion and thus depressive symptoms. C957T

Another polymorphism of the DRD2 gene that has been associated with variability in DRD2 binding and cognitive functions is the C957T polymorphism (rs6277) (Hirvonen et al., 2009a). This synonymous SNP, where T is replaced by C at base pair 957 of the DRD2 gene, influences mRNA stability and thus DRD2 gene expression, such that the T allele is associated with a decrease in DRD2 mRNA stability and therefore a decrease in receptor synthesis (Duan et al., 2003). However, in humans, the presence of the CC genotype is associated with low binding potential in the striatum, TT with high potential, and intermediate potential in heterozygotes (Hirvonen et al., 2004, 2009b). In extra-striatal areas, such as the thalamus and cortex, binding potential seems to be reversed, with the CC genotype showing the highest potential, and the TT the lowest (Hirvonen et al., 2009b). The differences noted in these studies have been attributed to differences in receptor affinity in different brain areas (Hirvonen et al., 2009b).

This polymorphism, particularly carrying the $\mathrm{C}$ allele, is considered a vulnerability factor for schizophrenia, a disorder recognized for deficits in cognitive function, such as, perseveration, attention, and executive function (Xu et al., 2007; Monakhov et al., 2008). Furthermore, participants with two $\mathrm{C}$ alleles reported elevated depressive rumination (i.e. lack of inhibition of negative thoughts) compared to T allele carriers (Whitmer and Gotlib, 2012). This indicates that the $C$ allele, and in turn low DRD2 binding in the striatum and heightened binding in extra-striatal regions, may influence cognitive functioning. When a 
concussion is endured, this cognitive dysfunction in C allele carriers may be exacerbated, increasing vulnerability to depression. 


\section{Hypotheses}

The purpose of the present investigation was to examine potential cognitive, experiential, and genetic predictors of depressive symptoms in students with a history of concussion. It was hypothesized that:

1. Depressive symptoms would be elevated in those who reported a history of concussion. Since the female gender has been found to be a significant risk factor for poor recovery after concussion in younger populations (Zemek et al., 2016), it was hypothesized that depressive symptoms would be particularly elevated in females with a history of concussion.

2. Concussion incidence would moderate the relationship between executive functioning and depressive symptoms, such that depressive symptoms would be elevated in those with poor executive function and a history of concussion.

3. Concussion incidence would moderate the relationship between dysfunctional attitudes and depressive symptoms, such that depressive symptoms would be elevated in those with high dysfunctional attitudes and a history of concussions.

4. Concussion incidence would moderate the relationship between early life adversity, particularly sexual and physical trauma, such that depressive symptoms would be elevated in those who experienced high levels of trauma and reported a history of concussion.

5. Concussion incidence would interact with the BDNF Val ${ }^{66} \mathrm{Met}$, COMT Val ${ }^{158} \mathrm{Met}$, Taq1A, and C957T polymorphisms to predict elevated depressive symptoms, such that elevated depressive symptoms would be seen in those who reported a history 
of concussion and carry the BDNF Val ${ }^{66}$ Met A allele, COMT Val158Met $\mathrm{G}$ allele, Taq1A T allele, or C957T C allele.

6. There would be a three-way moderation between concussion incidence, trauma, and genetic polymorphisms, such that depressive symptoms are elevated in those who have experienced a concussion, have a polymorphism associated with poor cognition, and report experiencing high levels of trauma. 


\section{Methods}

\section{$\underline{\text { Participants }}$}

Approximately 500 male and female undergraduate students were recruited using the online SONA system at Carleton University (Appendix A). Of the original 509 recruited participants, 319 were used for the experiential/ cognitive part of the study, where those who reported a concussion $(n=105, n$ female $=55, n$ male $=50$, M age $=19.12, \mathrm{SD}=1.65)$ and did not $(n=215, n$ female $=119, n$ male $=95, \mathrm{M}$ age $=19.03, \mathrm{SD}=1.66)$ were matched for age and gender. This sample comprised of $54.5 \%$ females $(n=174, \mathrm{M}$ age $=18.89, \mathrm{SD}=$ $1.59)$ and $45.5 \%$ males $(n=145, \mathrm{M}$ age $=19.26, \mathrm{SD}=1.72)$. The frequency of the polymorphisms of interest have been found to vary by ethnicity (Verhagen et al., 2010; Xie et al., 2015), therefore 157 White/Euro-Caucasians were used for further genetic analysis to allow for a homogenous ethnic sample. Those who reported a concussion $(n=73, n$ female $=33, n$ male $=40, \mathrm{M}$ age $=19.16, \mathrm{SD}=1.71)$ and did not $(n=84, n$ female $=43, n$ male $=41, \mathrm{M}$ age $=18.89, \mathrm{SD}=1.56)$ were matched for age and gender. This sample comprised of $48.4 \%$ females $(n=76, \mathrm{M}$ age $=18.87, \mathrm{SD}=1.59)$ and $51.6 \%$ males $(n=81, \mathrm{M}$ age $=19.16, \mathrm{SD}=1.67)$

\section{$\underline{\text { Procedure }}$}

The Psychology Research Ethics Board at Carleton University approved the study protocol. Participant data was collected between September 2013 and December 2015. Once participants arrived, they were informed of the study procedure and their written consent (Appendix B) was obtained. Once consent was obtained, the participants were asked to provide a saliva sample and complete a Background Information questionnaire 
(Appendix D). Next, a computer-based experimental task (Appendix E), the Wisconsin Card Sorting Task (WCST; Grant and Berg, 1948), was administered using the Psychology Experiment Building Language software system (PEBL; Mueller and Piper, 2014). Once the computer task was complete, participants were then asked to complete the remainder of the questionnaires, including: Dysfunctional Attitudes Scale- Short Form (DAS-SF; Beevers et al., 2007; Appendix F), Mild Traumatic Brain Injury Survey (Appendix G), Early Trauma Inventory- Self Report (ETI-SR; Bremner et al., 2007; Appendix H), and the Beck Depression Inventory- 21 item (BDI; Beck et al., 1961; Appendix I). Once all measures of the study were complete, the participants were debriefed (Appendix C).

\section{Genotyping}

Norgen collection kits (Norgen Biotek Corp., Thorold, Ontario Canada) were used to collect saliva samples ( $\sim 2 \mathrm{ml})$ for genotyping. Extractions of genomic DNA were performed following the instructions provided by the manufacturer. Once extracted, DNA was stored at $-80^{\circ} \mathrm{C}$. Each sample was then diluted using diethylpyrocarbonate (DEPC) water to approximately equal concentrations $(20 \mathrm{ng} / \mu \mathrm{l})$. Diluted samples of approximately $35 \mu \mathrm{l}$ were sent to McGill University and Génome Québec innovation Centre (Montreal, Canada) for genotyping. DNA was first amplified using polymerase chain reaction (PCR). Once unincorporated deoxynucleotides were removed with shrimp alkaline phosphatase, oligonucleotide extension primers and an extension enzyme was added to add a single base extension for each SNP site. Clean Resin was then used to desalt the extension products, before they were transferred onto a SpectroCHIP® Array. A Mass Spectrometer and manual analysis was then used to detect DNA based on separation time. Primer sequences used for genotyping were as follows: 
C957T forward: ACGTTGGATGCATGGTCTGGATCTCAAA

C957T reverse: ACGTTGGATGAGCCACCACCAGCTGACTCT, C957T probe: acGTTTGGCGGGGCTGTC

COMT Val ${ }^{158}$ Met forward: ACGTTGGATGGTCAGGCATGCACACCTTG COMT Val ${ }^{158}$ Met reverse: ACGTTGGATGTGTGGCTACTCAGCTGTG COMT Val ${ }^{158}$ Met probe: atcCACACCTTGTCCTTCA

BDNF Val ${ }^{66}$ Met forward: ACGTTGGATGTACTGAGCATCACCCTGGA BDNF Val ${ }^{66}$ Met reverse: ACGTTGGATGGCTTGACATCATTGGCTGAC BDNF Val ${ }^{6}$ Met probe: TCCAACAGCTCTTCTATCA

The genotype distributions for total Caucasian participants (Table 1, 2, and 3) met Hardy-Weinberg Equilibrium expectations for C957T rs6277, $\chi^{2}(1)=0.98, p=0.32$, COMT rs4680, $\chi^{2}(1)=0.61, p=0.43$, and BDNF rs6265, $\chi^{2}(1)=2.72, p=0.10$. When separated by gender, the genotype distributions for Caucasian participants (Table 1, 2, and 3) also met Hardy-Weinberg Equilibrium expectations: for females, C957T rs6277, $\chi^{2}(1)=0.00, p=$ 0.99, COMT rs4680, $\chi^{2}(1)=0.52, p=0.47$, and BDNF rs6265, $\chi^{2}(1)=2.88, p=0.09$, and males, C957T rs6277, $\chi^{2}(1)=1.96, p=0.16$, COMT rs4680, $\chi^{2}(1)=0.15, p=0.70$, and BDNF rs6265, $\chi^{2}(1)=0.38, p=0.54$. Genotypes of the Taq1A SNP were unable to be determined and therefore excluded from analyses. 14 participants were also excluded from genotype analyses, as their genotype was unable to be determined. 
Table 1. Allele distributions for DRD2 polymorphisms

\begin{tabular}{lccc}
\hline C957T rs6277 & TT & TC & CC \\
\hline Total & 56 & 63 & 25 \\
Females & 25 & 36 & 13 \\
Males & 31 & 27 & 12 \\
\hline
\end{tabular}

Table 2. Allele distributions for COMT polymorphisms

\begin{tabular}{lccc}
\hline Val $^{158}$ Met rs4680 & GG & GA & AA \\
\hline Total & 37 & 76 & 30 \\
Females & 18 & 39 & 15 \\
Males & 19 & 37 & 15 \\
\hline
\end{tabular}

Table 3. Allele distributions for BDNF polymorphisms

\begin{tabular}{lccc}
\hline Val 66Met rs6265 & GG & GA & AA \\
\hline Total & 100 & 44 & 1 \\
Females & 48 & 24 & 0 \\
Males & 51 & 20 & 1 \\
\hline
\end{tabular}

$\underline{\text { Measures }}$

Background Information

Background information was assessed using a questionnaire investigating the gender, age, ethnicity, and health of the participant (Appendix D). 
Set- Shifting

A computerized version of the Wisconsin Card Sorting Task (WCST; Grant and Berg, 1948; Appendix E), using the PEBL experiment building software (Mueller, 2011), was used as a test of set-shifting. The participant was presented with four decks of cards with a different colour, number, and shape presented in each deck. A card was presented to the participant and they were instructed to sort the card to one of the four decks based on the colour, number and shape presented on the card. The correct deck for sorting was dependent on a rule that was unknown. After each trial, the participant was told if their selection was "correct" or "incorrect". The rule changed after approximately every $10^{\text {th }}$ trial. This continued for a total of 128 trials. The number of correct and incorrect responses was tallied for each participant, as well as perseverative responses, perseverative errors, and non-perseverative errors. High perseverative errors, where the participant continued to sort cards incorrectly despite negative feedback to indicate the response was incorrect, indicated poor set-shifting abilities.

\section{Dysfunctional Attitudes}

Dysfunctional attitudes were assessed using the Dysfunctional Attitudes Scale- Short Form (DAS-SF; Beevers et al., 2007; Appendix F ). The DAS-SF is a 9-item scale assessing dysfunctional beliefs that are thought to reflect self-evaluation, including concerns about approval from others, prerequisites for happiness, and perfectionist standards. For each item, the respondent indicated how much the statement described their general attitude from 1 (Totally Agree) to 4 (Totally Disagree). The score for each item was subtracted from 5 and summed to compute the total dysfunctional attitudes $(\alpha=0.81)$. Items such as 'if I fail at my work, then I am a failure as a person ' can be found in this scale. 


\section{Concussion History}

Concussion history was assessed using a questionnaire (Appendix G) asking if the participant has experienced a mild traumatic brain injury (concussion), how many concussions they have experienced, the medical care that they received, and certain symptoms they experienced as the result of their injury.

\section{Early Life Trauma}

Early life trauma was assessed using the Early Trauma Inventory- Self Report (ETISR; Bremner et al., 2007; Appendix H). The ETI-SR consists of a 27-item questionnaire that assesses traumatic events of general (11-items), physical (5-items), emotional (5-items), and sexual (6-items) nature. For each item, the respondent indicated on a scale of 0 (Never) to 5 (More than 10 times) how often they experienced the trauma given, between the ages of 0 to 5,6 to 12,13 to 18 , or $18+$. Total trauma was calculated by summing the trauma experienced for all items $(\alpha=0.94)$. Trauma experienced in each age range was also calculated, as well as each type of trauma (physical $\alpha=0.90$, general $\alpha=0.82$, sexual $\alpha=$ 0.74, emotional $\alpha=0.92$ ) by summing the scores indicated for each category. Higher scores indicated more traumas experienced. Due to the significant impact of previous sexual and physical abuse on recovery after concussion, as shown by van Veldhoven and colleagues (2011), these types of trauma were of specific interest. However, due to the low frequency of sexual abuse in males and the interest of assessing gender effects, physical abuse was focused on for the present study. Items such as 'were you ever burned with hot water, a cigarette or something else?' can be found in this scale. 


\section{Depressive Symptoms}

The quantity of depressive symptoms was measured using the Beck Depression Inventory (BDI; Beck et al., 1961; Appendix J). The BDI is a 21- item inventory where the individuals choose the statement that best describes their depressive symptomology. Depressive symptoms are indicated on a number scale starting at lower symptoms (e.g. $0=$ 'I do not feel sad') and increasing to high depressive symptoms (e.g. 4 = 'I am so sad or unhappy that I can't stand it'). Total depressive symptoms were calculated by summing across all items $(\alpha=0.92)$.

\section{$\underline{\text { Additional Measures }}$}

Due to the nature of this research, additional computer tasks (Appendix J) and questionnaires (Appendix K) were conducted at the same time as the ones described above. The data from these measures will be used for other studies. 


\section{Statistical Analysis}

SPSS Statistics Software for Windows 18.0 (SPSS Science, Chicago, IL, USA) was used for all statistical analyses. Statistical significance was determined at $p<0.05$ (two-tailed) and standardized scores were used for statistical analyses. Correlation analyses were first conducted to examine the relationships between concussion incidence, gender, trauma, dysfunctional attitudes, executive functions, and depression. Next, analysis of variance (ANOVA) and Bonferroni corrected $t$ - tests were used to compare between groups. Hierarchical regression analyses were performed to determine relationships between concussion incidence, trauma, dysfunctional attitudes, executive functions, genotypes, and depression for each gender. Significant moderations were then analyzed further using a web utility for simple slopes (Preacher et al., 2006). Lastly, multivariate analysis of variance (MANOVA) was used to assess the relationship between concussion incidence, genotypes, and depression. 


\section{Results}

Experiential and Cognitive Contribution to Depressive Symptoms in Male and Female Students with a History of Concussion

Separate correlational analyses were performed on males and females with respect to concussion incidence, physical trauma, perseverative errors, dysfunctional attitudes, and depressive symptoms. For females, bivariate correlation analyses indicated that concussion incidence was positively correlated with dysfunctional attitudes and depressive symptoms (Table 4). Additionally, depressive symptoms were positively correlated with physical trauma and dysfunctional attitudes.

Table 4. Pearson Correlations depicting relations between physical trauma, dysfunctional attitudes, perseverative errors, and depressive scores in females (n= 174)

\begin{tabular}{lllll}
\hline Situation & 1. & 2. & 3. & 4. \\
\hline 1. Concussion Incidence &. & & & \\
2. Physical Trauma & .036 &. & & \\
3. Perseverative Errors & -.116 & .023 &. & \\
4. Dysfunctional Attitudes & $.153^{*}$ & .119 & -.055 &. \\
5. Depressive Symptoms & $.162^{*}$ & $.243^{* *}$ & .070 & $.616^{* *}$ \\
\hline
\end{tabular}

$*=\mathrm{p}<0.05$ and $^{* *}=\mathrm{p}<0.01$

In males, bivariate correlational analyses revealed physical trauma to be positively correlated with perseverative errors and depressive symptoms (Table 5). Additionally, depressive symptoms were positively correlated with dysfunctional attitudes. 
Table 5. Pearson Correlations depicting relations between physical trauma, dysfunctional attitudes, perseverative errors, and depressive scores in males ( $n=145)$

\begin{tabular}{lllll}
\hline Situation & 1. & 2. & 3. & 4. \\
\hline 1. Concussion Incidence &. & & & \\
2. Physical Trauma & .036 &. & & \\
3. Perseverative Errors & -.081 & $.204^{*}$ &. & \\
4. Dysfunctional Attitudes & -.011 & .021 & .032 &. \\
5. Depressive Symptoms & .002 & $.332^{* *}$ & .121 & $.314^{* *}$ \\
\hline
\end{tabular}

$*=\mathrm{p}<0.05$ and $^{* *}=\mathrm{p}<0.01$

Females were found to have higher depressive scores than males, $t(1,314.63)=-$ $4.99, p<0.01$, but males reported higher levels of total physical trauma overall $t(1,254.82)$ $=5.35, p<0.01$ and specifically, physical trauma between 6 and 12 years of age, $t(1$, $269.59)=4.08, p<0.01,13$ and 18 years of age, $t(1,268.13)=5.36, p<0.01$, and after 18 years of age, $t(1,196.38)=4.85, p<0.01$. There were no sex differences in dysfunctional attitudes, $t(1,303.92)=0.31, p=0.76$, perseverative errors, $t(1,282.79)=0.18, p=0.86$, or physical trauma experienced between ages 0 and $5, t(1,282.73)=1.71, p=0.09$.

\section{Depressive Symptoms}

To provide an initial assessment of the relationship between concussion incidence and depressive symptoms in males and females, separate t-tests were performed for each gender. Females who reported a history of concussion were found to have significantly higher depressive symptom scores than those who did not, $t(1,172)=-2.154, p<0.05$ (Figure 1). This relationship between concussion incidence and depressive symptoms was not found for males, $t(1,143)=-0.03, p=0.98$ (Figure 2). 


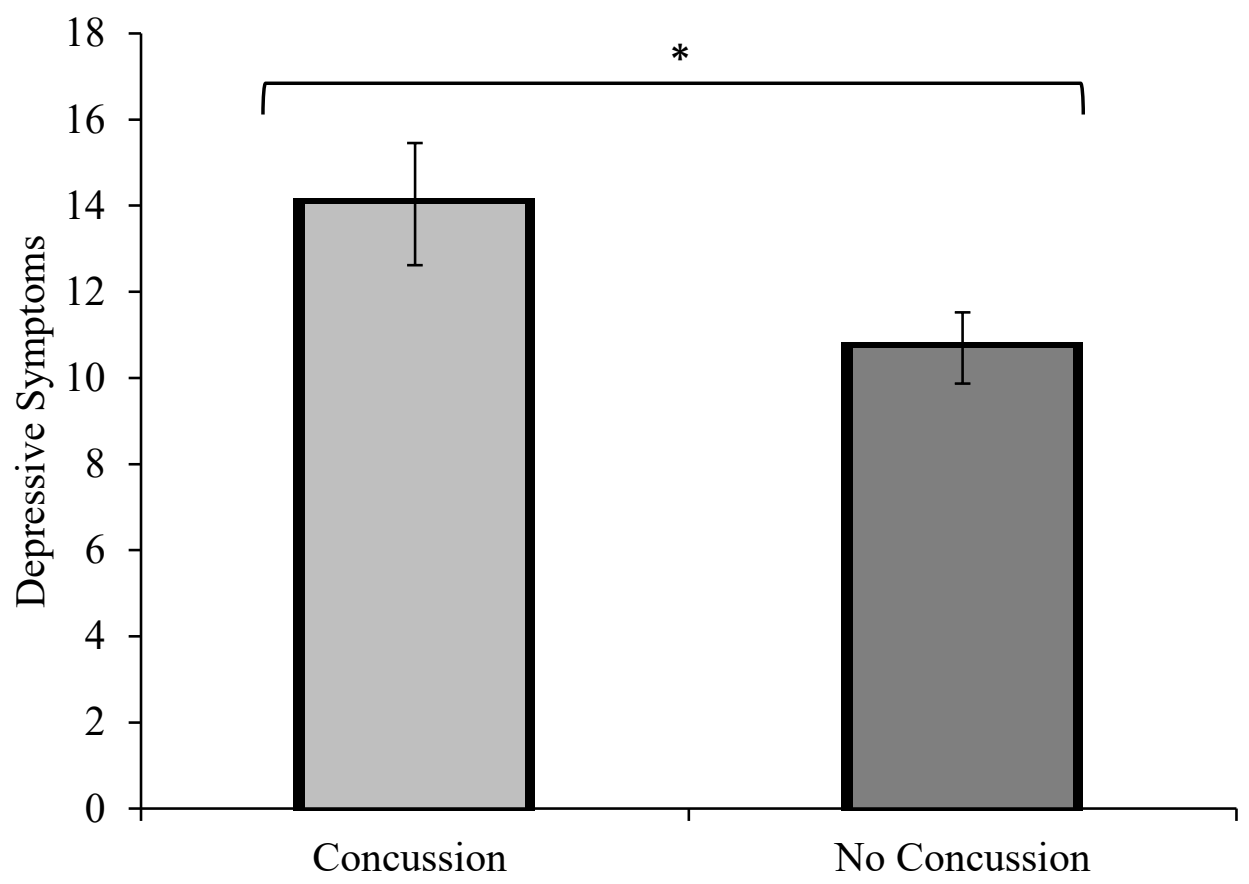

Figure 1. Changes in depressive symptom score as a function of reported concussion incidence in females. Those who reported a history of concussion had significantly increased depressive symptoms compared to those that did not. * $p<0.05$ 


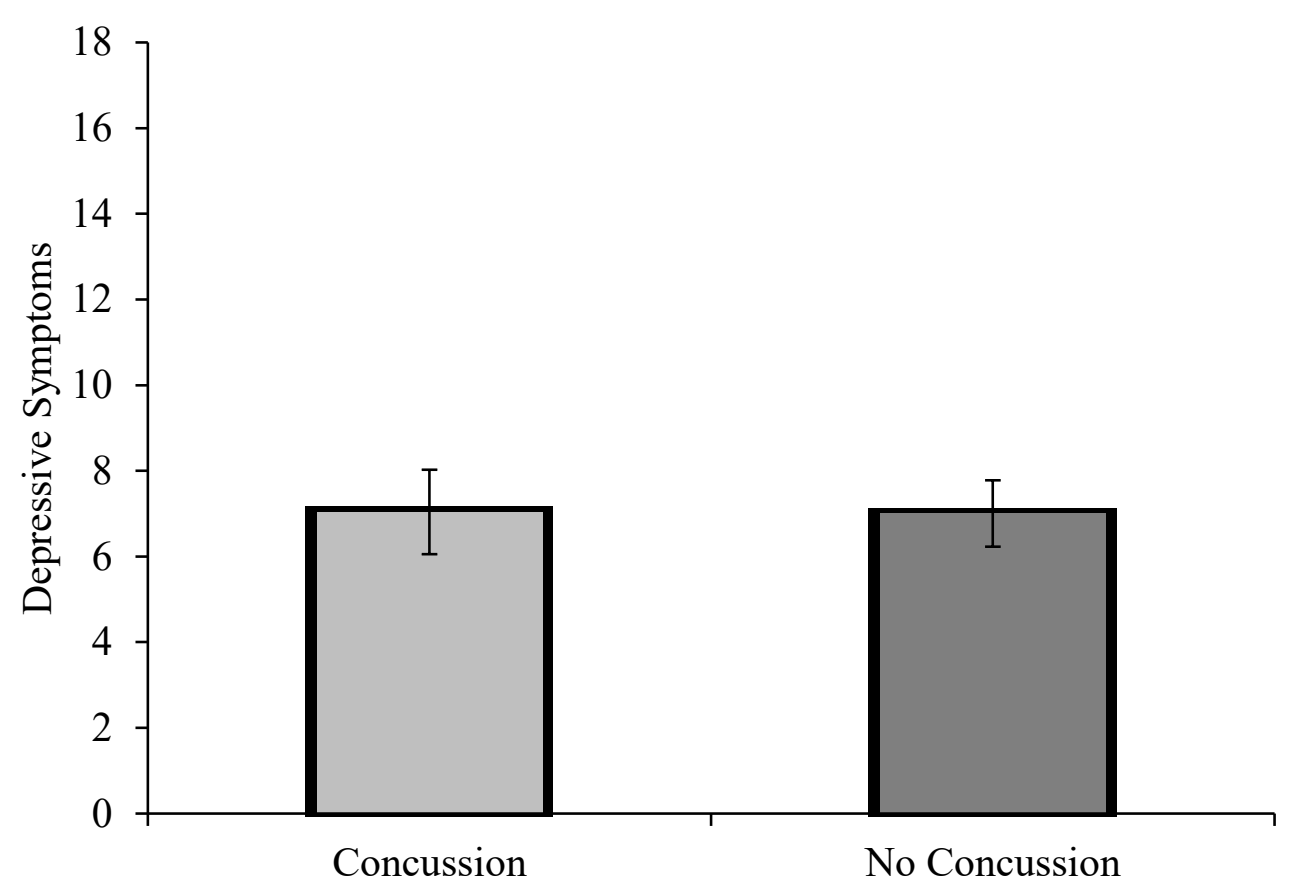

Figure 2. Changes in depressive symptom score as a function of reported concussion incidence in males. There were no significant differences in depressive symptoms based on concussion incidence.

\section{Physical Trauma}

To examine the relationship between physical trauma and depressive symptoms based on concussion incidence (yes or no), separate hierarchical linear regressions were conducted for each gender. Total physical trauma and concussion incidence were entered on the first step and the interaction between physical trauma and concussion incidence were entered on the second. For females, the moderating role of concussion incidence on the relation between total physical trauma and depression was significant, $\Delta R^{2}=0.03, b=$ 3.36, $t=-2.31, p=0.02$ (Figure 3). Follow up simple slope analyses (Preacher et al., 2006) revealed that at high physical trauma, levels of depressive symptoms did not differ with respect to concussion incidence. With low physical trauma, reported depressive symptoms 
were significantly fewer for those who did not report a history of concussion $(p<0.001)$ and were unchanged, from high physical trauma, for those with a history of concussion ( $p=$ $0.93)$.

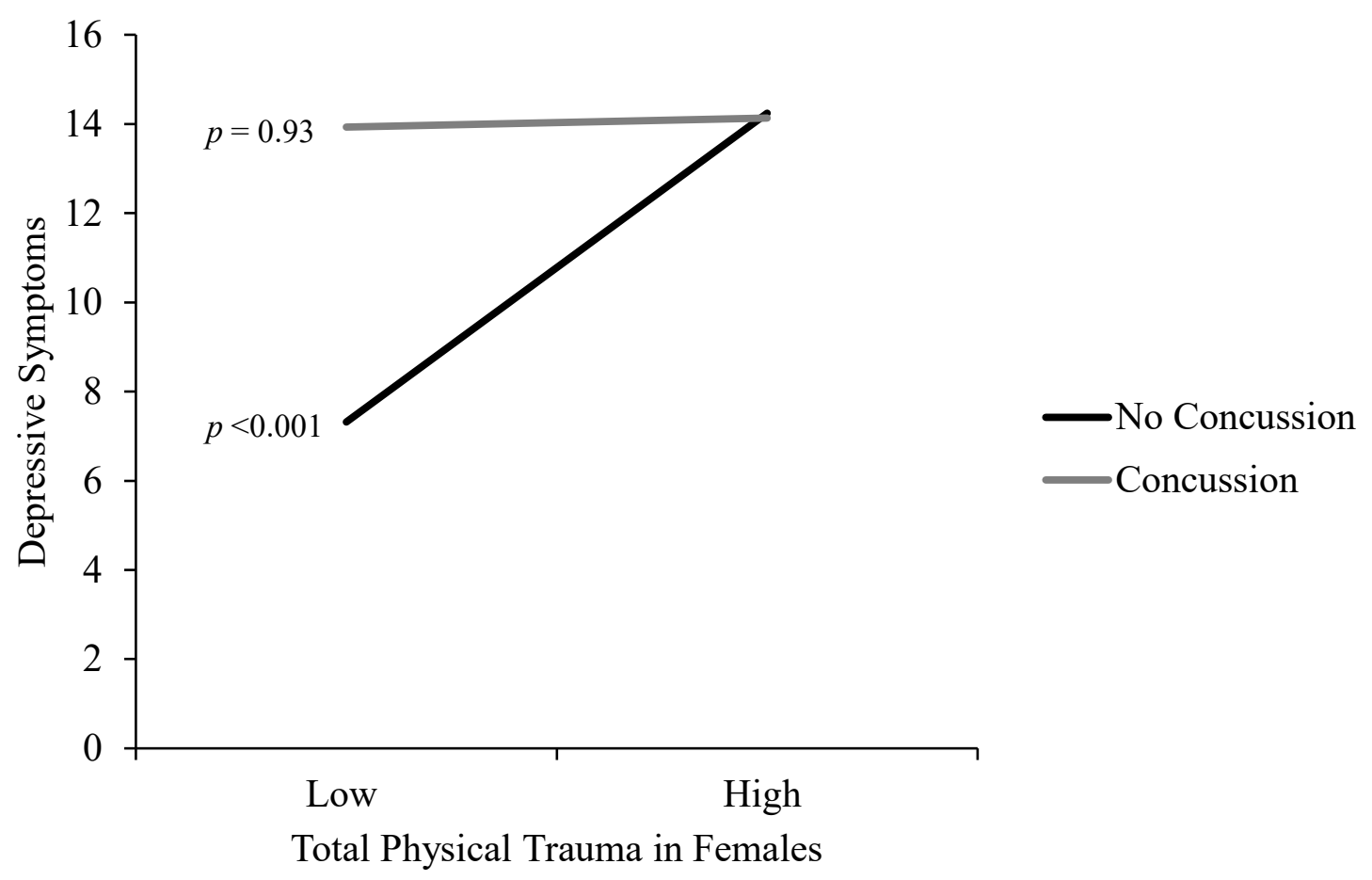

Figure 3. The relation between total physical trauma and depression scores as a function of concussive incidence in females. There was an interaction between concussion incidence and physical trauma in females. Follow up simple slope analyses revealed that depressive symptom scores did not differ at high levels of physical trauma. Depressive symptoms were significantly lower when lower levels of physical trauma were reported, but only among individuals without a history of concussion.

For males, the moderating role of concussion incidence on the relation between total physical trauma and depression was not significant, $\Delta R^{2}=0.001, b=-0.38, t=-0.31, p$ 
$=0.76$. Follow up simple slope analyses (Preacher et al., 2006) revealed that with low total physical trauma, depressive symptoms did not differ between those who reported a history of concussion and those who did not (Figure 4). At high levels of total physical trauma, depressive symptoms were significantly increased for both those who reported a history of concussion $(p<0.05)$ and those without a history of concussion $(p<0.001)$.

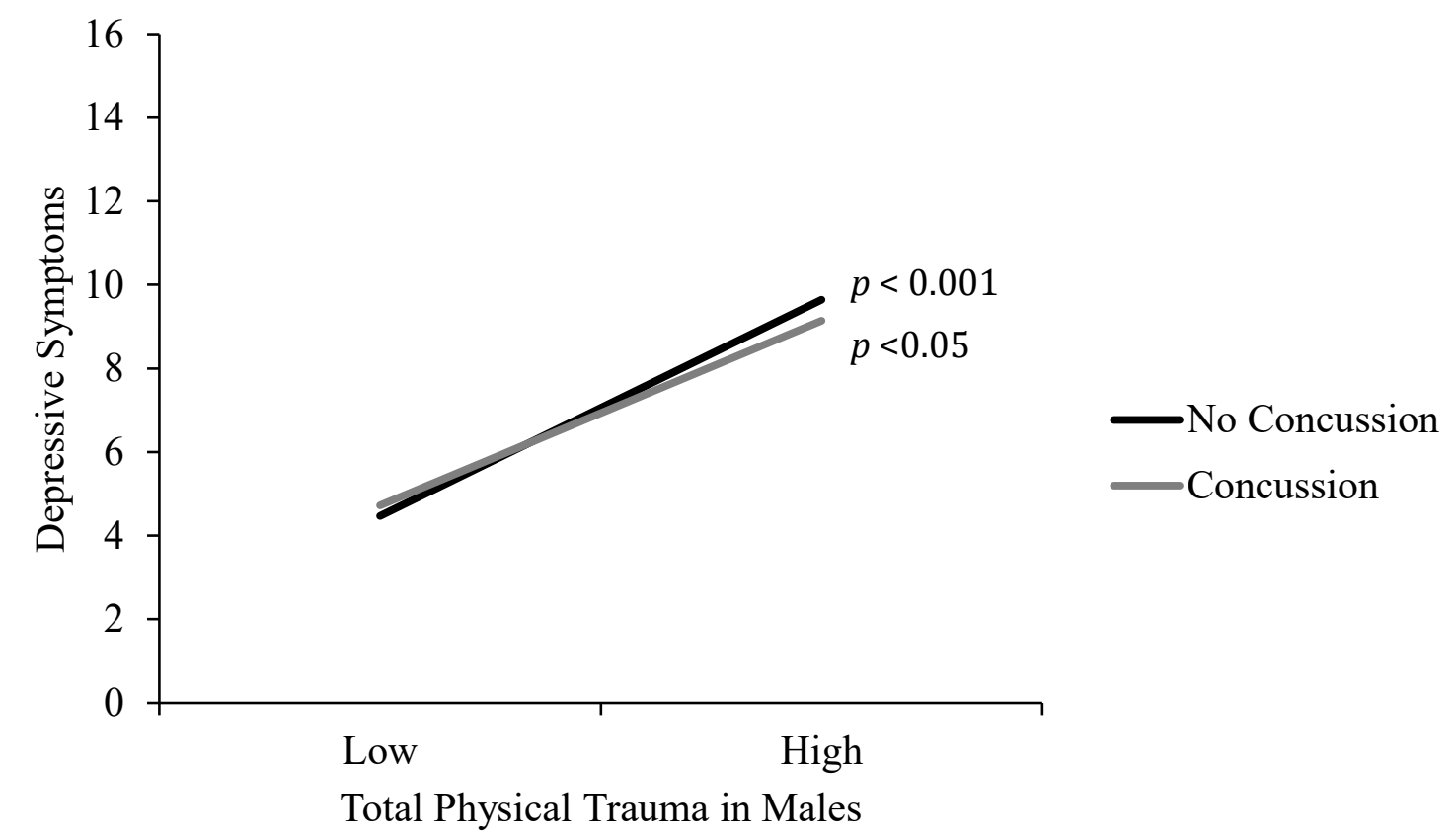

Figure 4. The relation between total physical trauma and depression scores as a function of concussive incidence in males. Simple slopes analyses revealed that with low total physical trauma levels, depressive symptoms were similar regardless of concussion history. At high levels of physical trauma, depressive symptoms were significantly increased for both those who reported a history of concussion and those without a history of concussion. 
Physical Trauma Experienced During Different Ages

To build on these findings, it was of interest to examine the potential interactive effects of physical trauma experienced at different ages ( 0 to 5,6 to 12,13 to 18 , and over 18 years of age) with concussion incidence using depressive symptoms as the outcome. Hierarchical linear regression was conducted using physical trauma experienced at each of the age groups and concussion incidence. Physical traumas experienced for each age group and concussion incidence were entered on the first step and the interaction between physical trauma experienced at that age and concussion incidence were entered on the second.

In females, concussion incidence interacted with physical trauma experienced between the ages of 6 and 12, $\Delta R^{2}=0.04, b=-3.78, t=-2.57, p=0.01$ to predict depressive symptoms (Figure 6). Follow up simple slope analyses (Preacher et al., 2006) showed that with high physical trauma, levels of depressive symptoms did not differ with respect to concussion incidence. With low physical trauma, depressive symptoms were significantly lower for those who did not report a history of concussion $(p<0.001)$ and were unchanged for those with a history of concussion $(p=0.66)$. Concussion incidence did not interact with physical trauma experienced at the other age groups (between ages 0 and $5, \Delta R^{2}=0.02, b=$ - 2.44, $t=-1.66, p=0.10,13$ and $18, \Delta R^{2}=0.01, b=-2.12, t=-1.33, p=0.19$, or over 18 $\left.\Delta R^{2}=0.01, b=-1.61, t=-1.10, p=0.27\right)$. Follow up simple slopes analyses revealed that for each age group, levels of depressive symptoms did not differ at high physical trauma with respect to concussion incidence $(p>0.05)$ but with low physical trauma, levels of 
depressive symptoms were significantly lower for those without a history of concussion ( $p$ $<0.05$ ), as shown in Figures 5, 7, and 8.

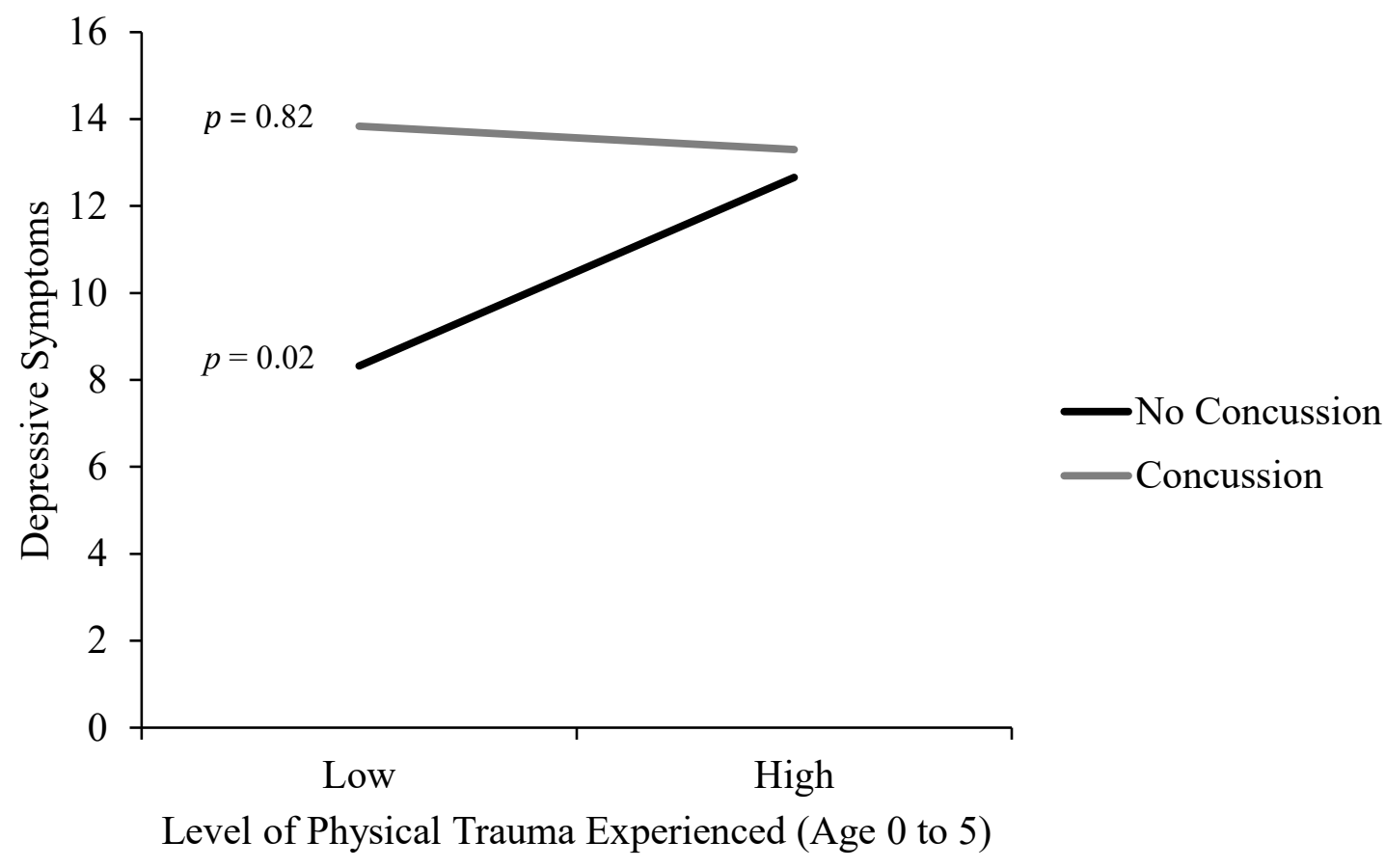

Figure 5. The relation between levels of physical trauma experienced between ages 0 and 5 and depression scores as a function of concussive incidence in females. Simple slope analyses revealed that depressive symptom scores did not differ at high levels of physical trauma. Depressive symptoms were significantly lower with lower levels of physical trauma were reported, but only among those individuals who did not report a history of concussion. 


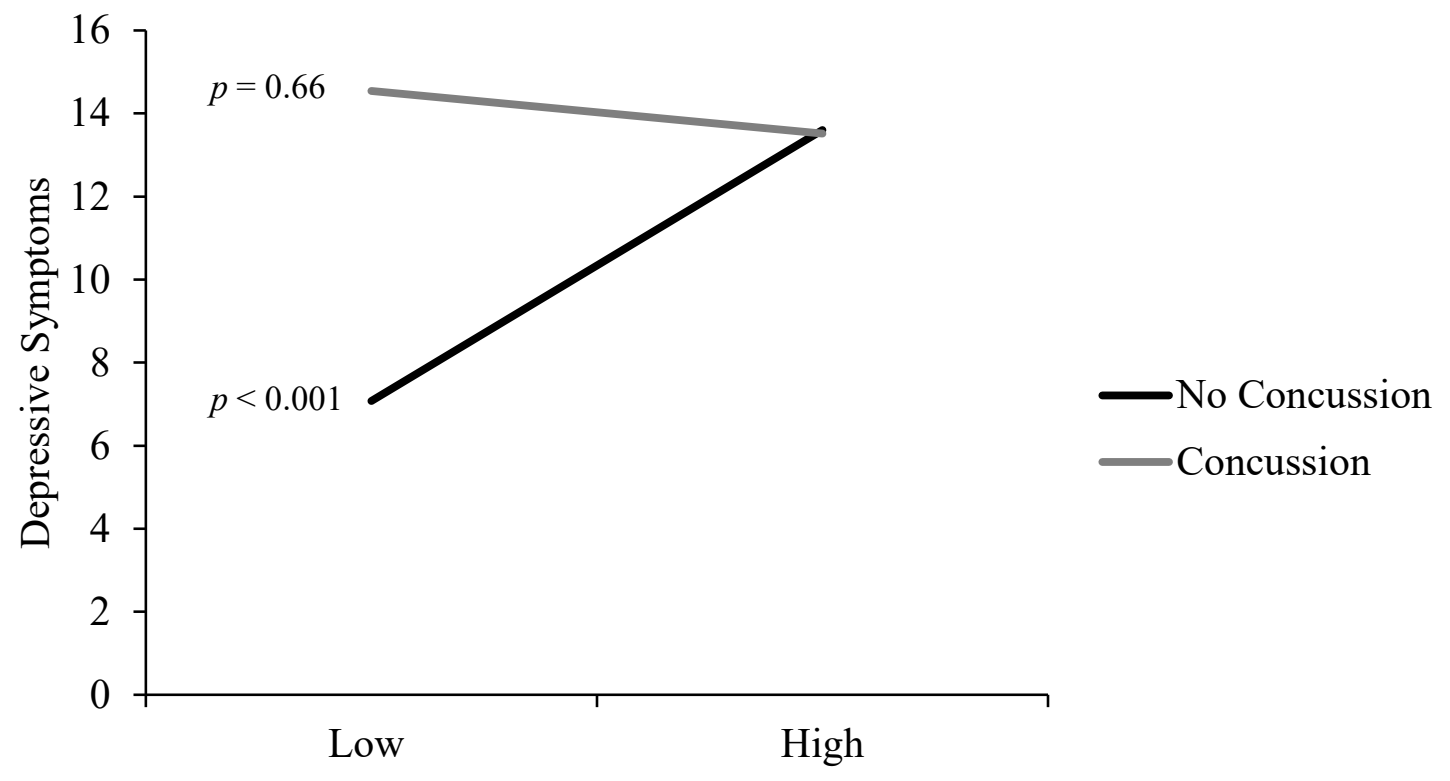

Level of Physical Trauma Experienced (Age 6 to 12)

Figure 6. The relation between levels of physical trauma experienced between ages 6 and 12 and depression scores as a function of concussive incidence in females. There was an interaction between concussion incidence and physical trauma experienced between ages 6 to 12 in females. Follow up simple slope analyses revealed that depressive symptom scores did not differ at high levels of physical trauma. Depressive symptoms were significantly lower when lower levels of physical trauma were reported, but only among individuals without a history of concussion. 


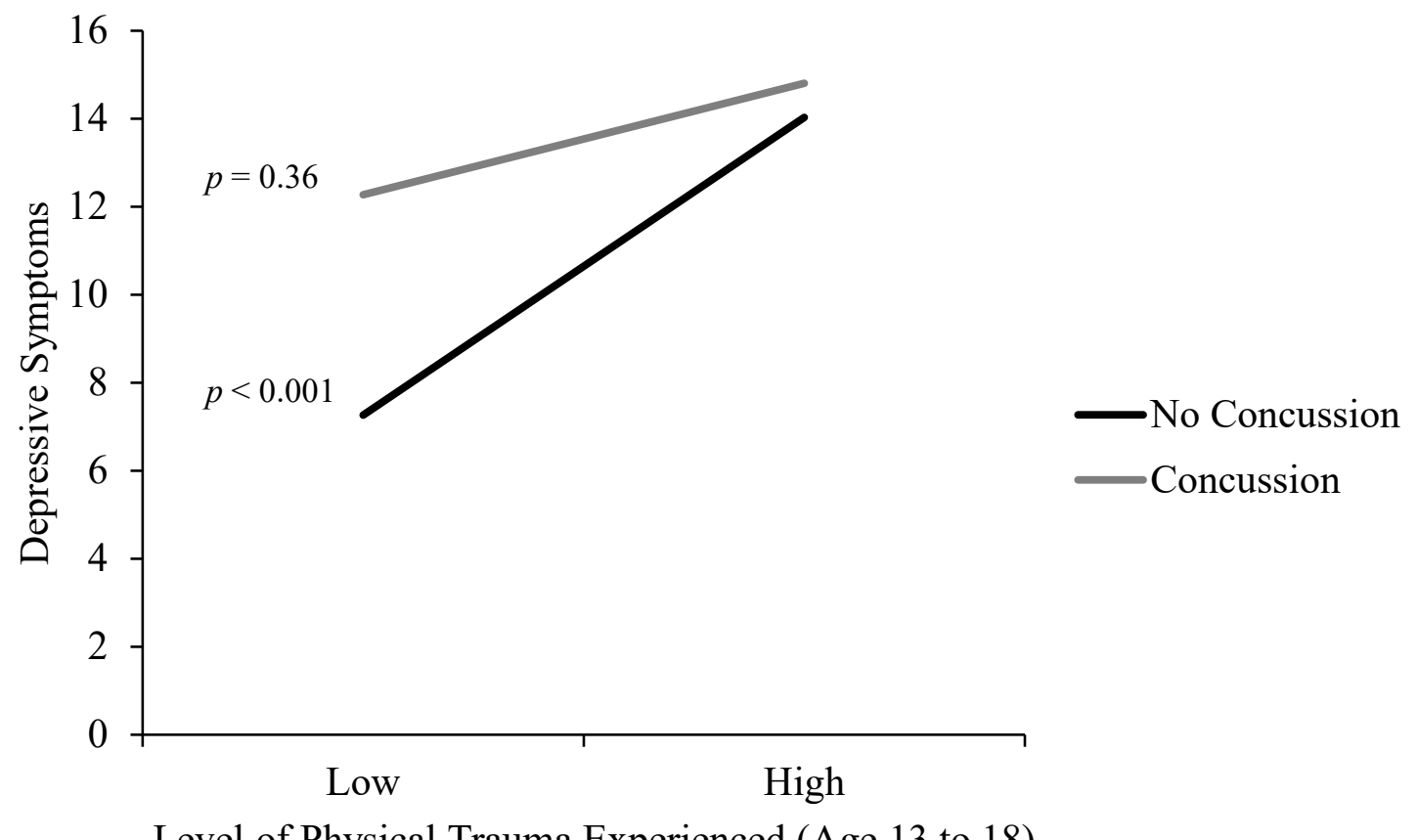

Level of Physical Trauma Experienced (Age 13 to 18)

Figure 7. The relation between levels of physical trauma experienced between ages 13 and 18 and depression scores as a function of concussive incidence in females.

Simple slopes analyses revealed that depressive symptom scores did not differ with high levels of physical trauma. Depressive symptoms were significantly lower with lower levels of physical trauma, but only among individuals without a history of concussion. 


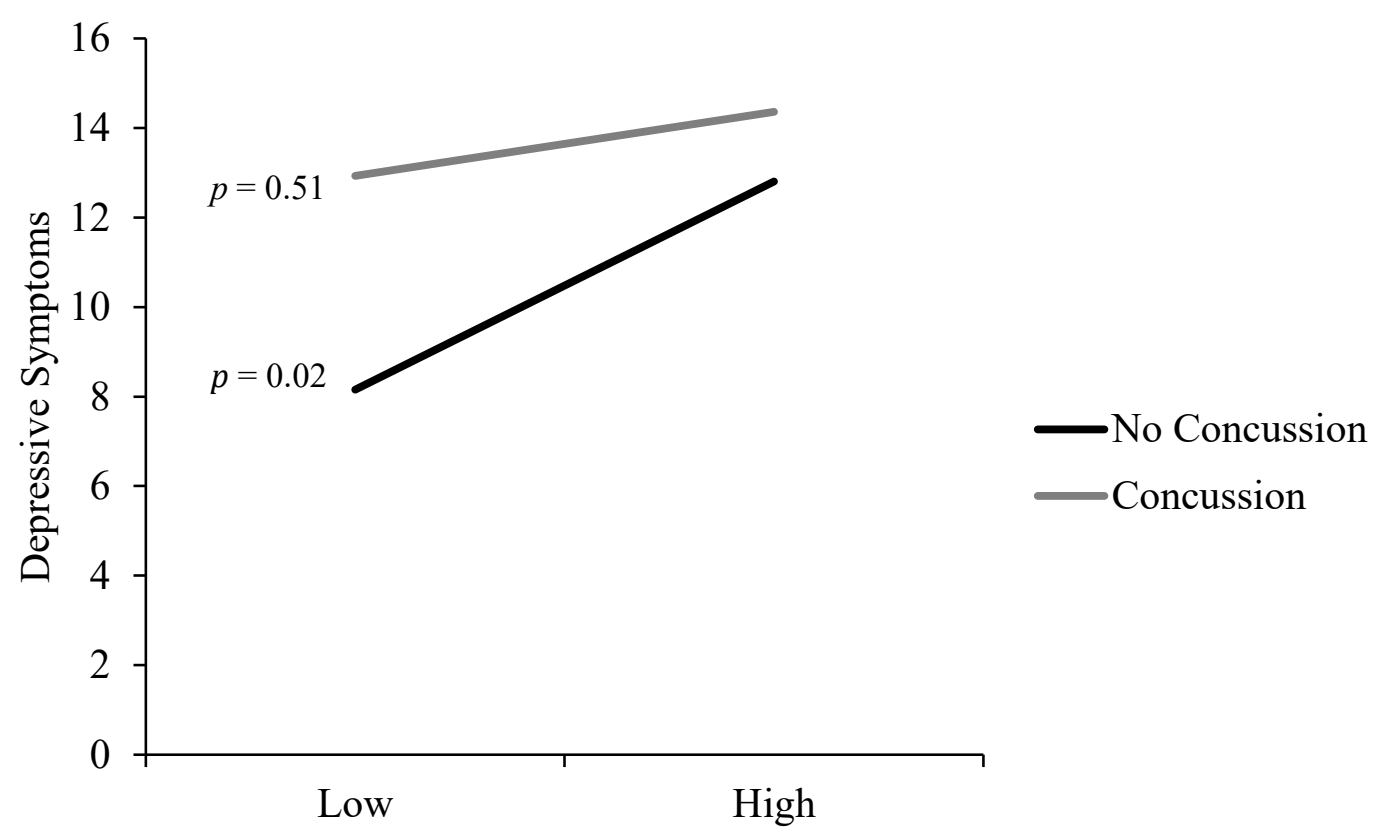

Level of Physical Trauma Experienced (Age 18+)

Figure 8. The relation between levels of physical trauma experienced after the age of 18 and depression scores as a function of concussive incidence in females. Simple slopes analyses revealed that depressive symptom scores did not differ at high levels of physical trauma. Depressive symptoms were significantly lower when lower levels of physical trauma were reported, but only among those individuals without a history of concussion.

The same analyses performed with the male participants revealed that concussion incidence did not interact with physical trauma experienced between ages 0 to $5, \Delta R^{2}=$ $0.010, b=-1.453, t=1.232, p=0.220,6$ to $12, \Delta R^{2}=0.001, b=0.582, t=0.460, p=0.646$, 13 to $18, \Delta R^{2}=0.007, b=-1.267, t=-1.032, p=0.304$, or after $18, \Delta R^{2}=0.002, b=-0.715, t$ $=-0.581, p=0.562$, to predict depressive symptom scores. Follow up simple slope analyses (Preacher et al., 2006) showed that with low physical trauma, depressive symptoms did not 
differ between those who reported a history of concussion and those who did not. At high levels of physical trauma experienced between the ages of 0 to 5 , depressive symptoms were increased for both those who reported a history of concussion $(p<0.001)$ and those who did not $(p=0.06)$ (Figure 9). This was similar for high levels of physical trauma experienced between the ages of 6 and 12 , for both a history of concussion $(p<0.05)$ and not $(p<0.05)$, and for high levels of physical trauma experienced after the age of 18 , for those with a history of concussion $(p<0.05)$ and not $(p<0.01)$ (Figures 10 and 12). Levels of depressive symptoms did not differ with high physical trauma experienced between the ages of 13 and 18 based on concussion incidence $(p=0.18)$ but with low physical trauma experienced between the ages of 13 and 18, levels of depressive symptoms were significantly lower for those who did not report a history of concussion $(p<0.001)$, as shown in Figure 11. 


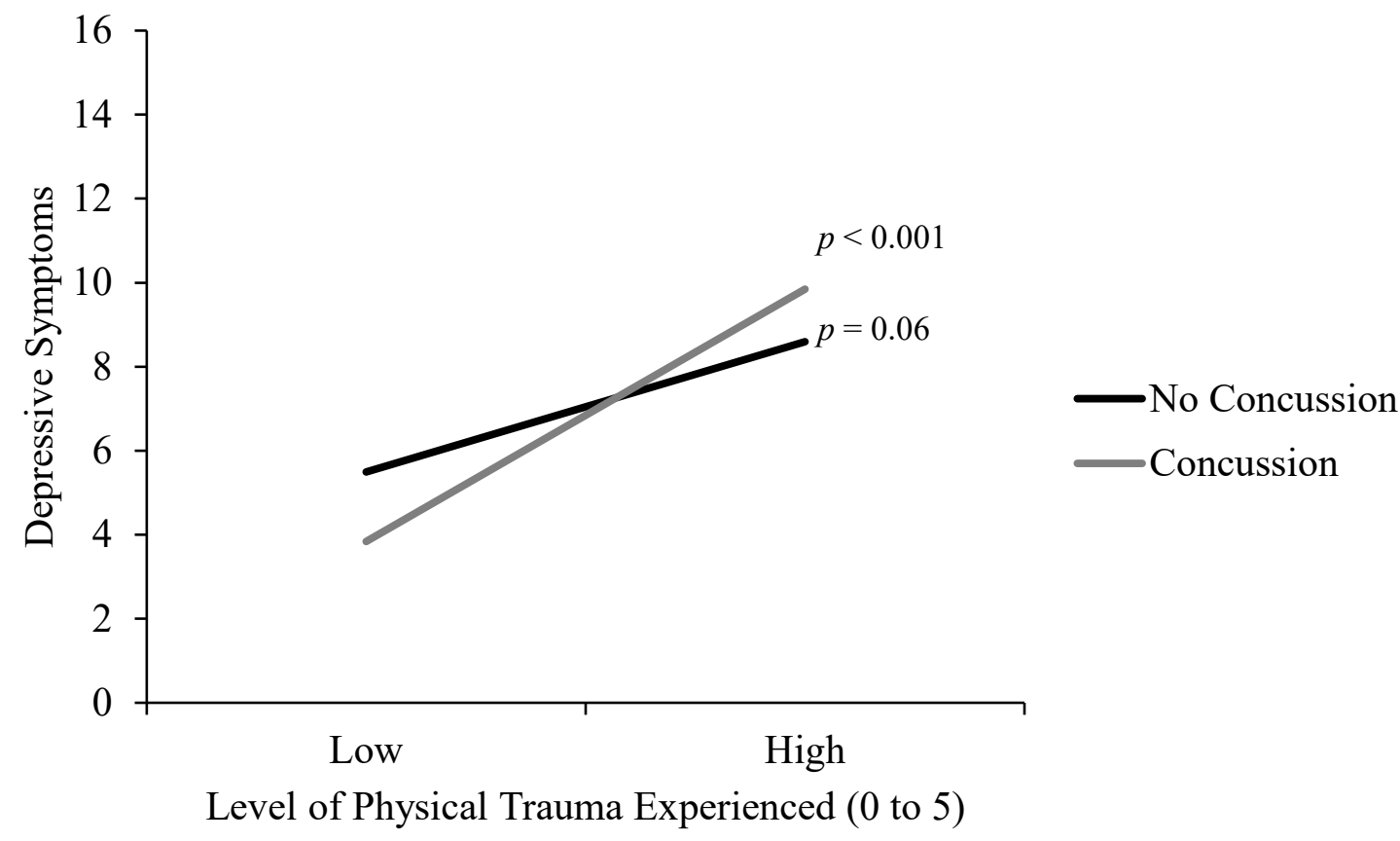

Figure 9. The relation between levels of physical trauma experienced between ages 0 and 5 and depression scores as a function of concussive incidence in males. Simple slopes analyses revealed that with low physical trauma, depressive symptoms were similar regardless of concussion history. At high levels of physical trauma, depressive symptoms were significantly higher for those who reported a history of concussion and those who did not. 


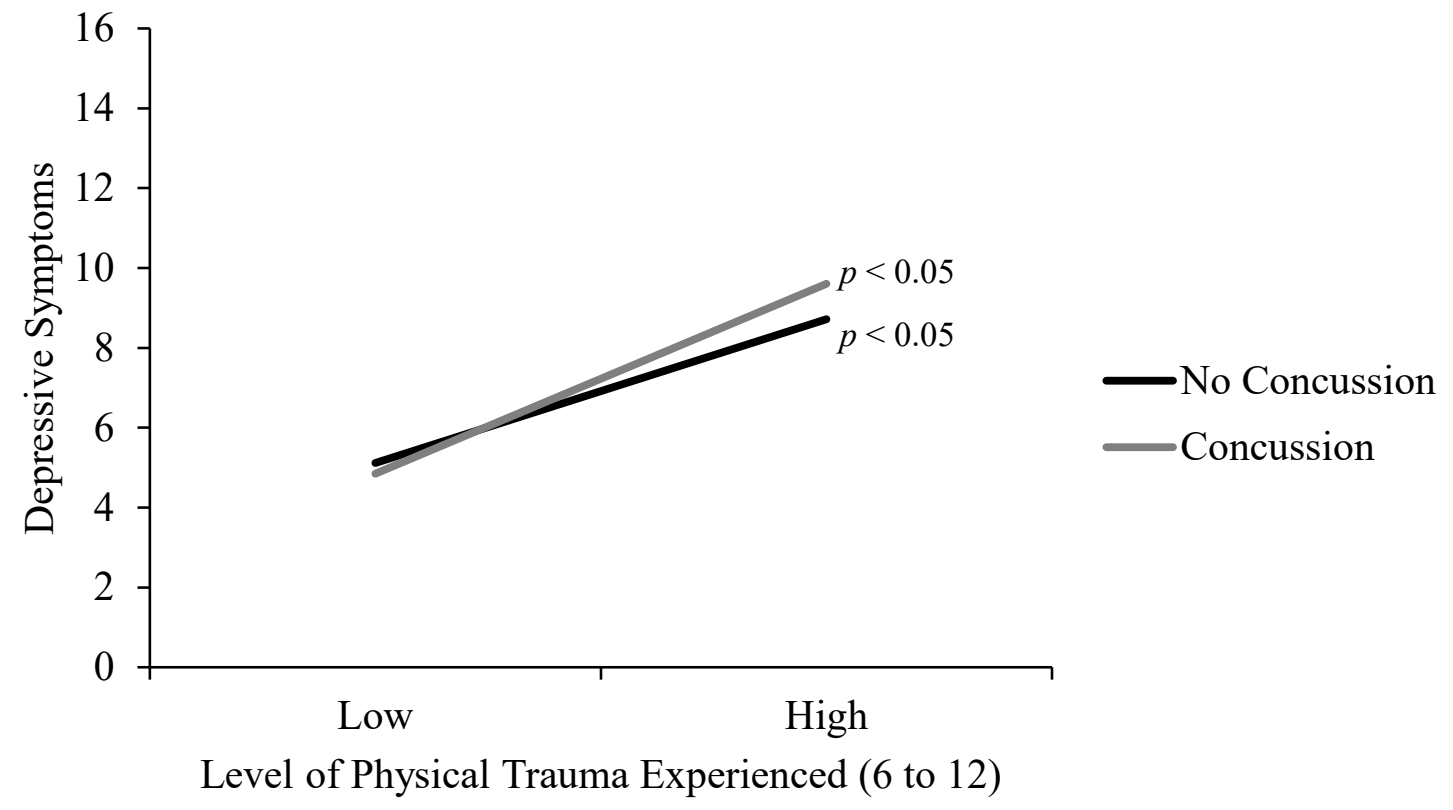

Figure 10. The relation between levels of physical trauma experienced between ages 6 and 12 and depression scores as a function of concussive incidence in males. Simple slopes analyses revealed that with low physical trauma, depressive symptoms were similar regardless of concussion history. With high levels of physical trauma, depressive symptoms were significantly higher for both those who reported a history of concussion and those who did not. 


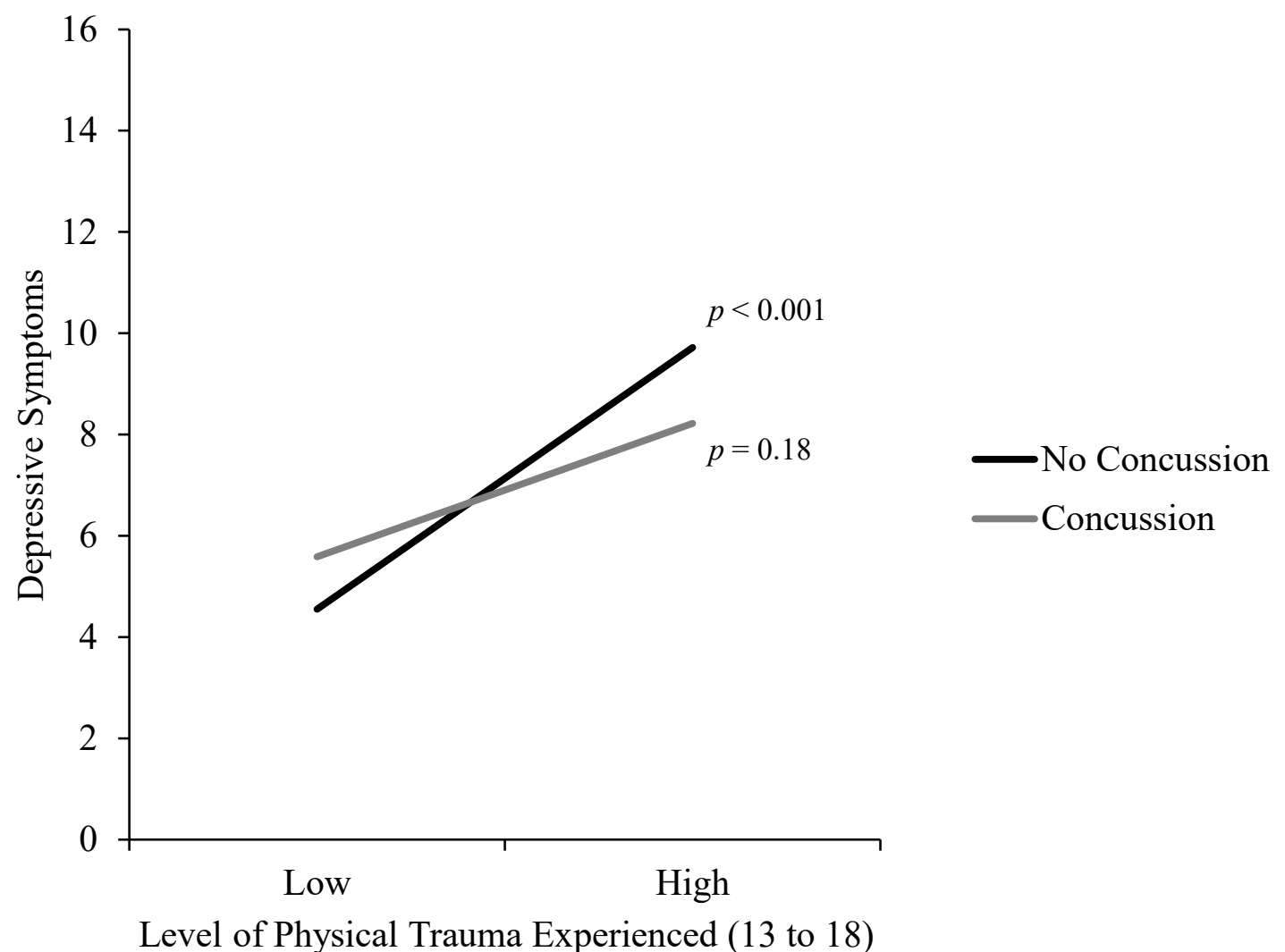

Figure 11. The relation between levels of physical trauma experienced between ages 13 and 18 and depression scores as a function of concussive incidence in males.

Simple slopes analyses revealed that with low physical trauma, depressive symptoms were similar regardless of concussion history. With high levels of physical trauma, depressive symptoms were significantly elevated for those who did not report a history of concussion but not for those without a history of concussion. 


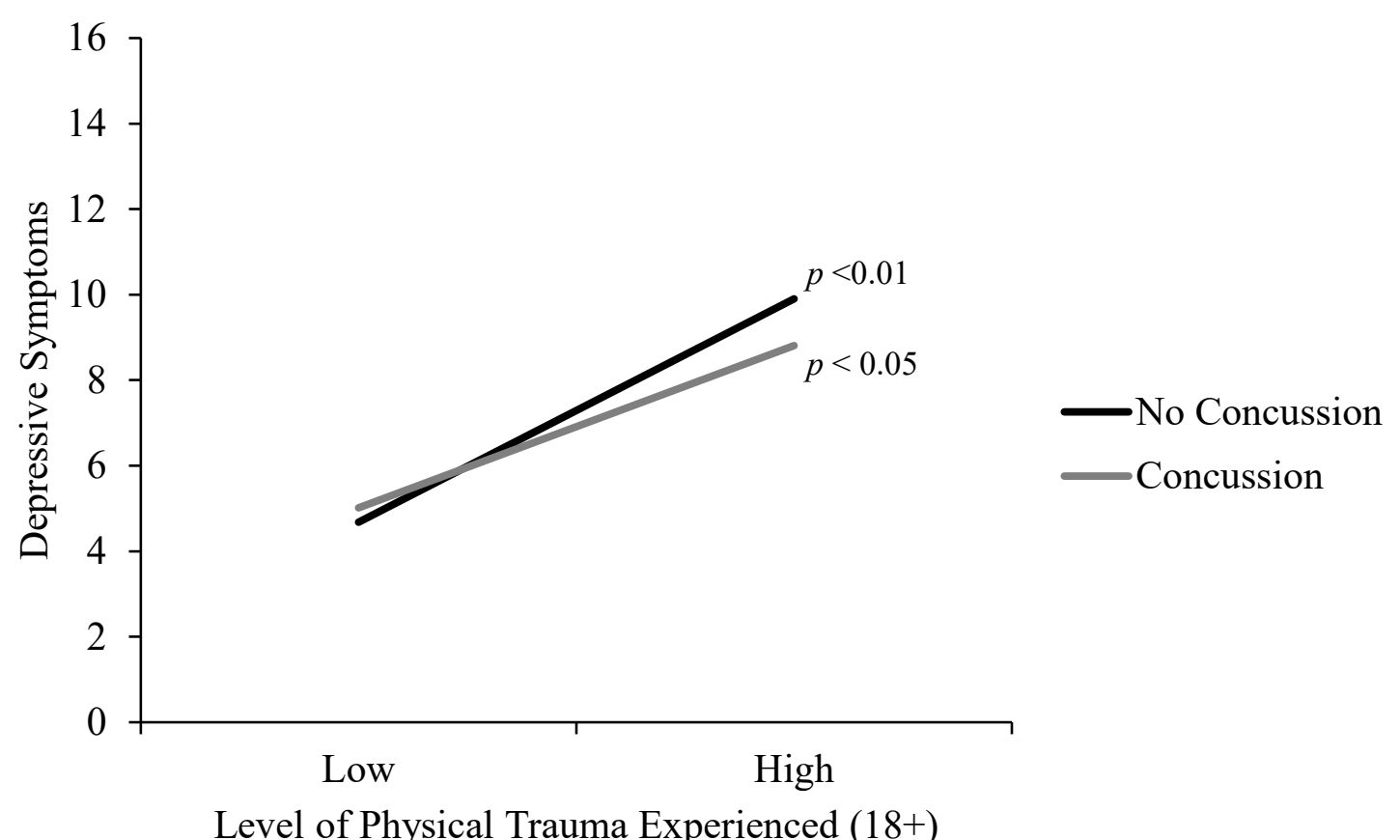

Figure 12. The relation between levels of physical trauma experienced after age 18 and depression scores as a function of concussive incidence in males. Simple slopes analyses revealed that with low physical trauma, depressive symptoms were similar regardless of concussion history. With high levels of physical trauma, depressive symptoms were significantly elevated for those who did and did not report a history of concussion.

\section{Dysfunctional Attitudes}

To examine whether concussion incidence and dysfunctional attitudes interacted to predict depressive symptoms, a hierarchical linear regression was conducted. Considering the sex differences revealed in the previous analyses, male and female gender were analyzed separately. Dysfunctional attitudes and concussion incidence were entered on the first step and the interaction between dysfunctional attitudes and concussion incidence were entered on the second. For females, there was a trend revealed for the moderating 
role of concussion incidence on the relation between dysfunctional attitudes and depression, $\Delta R^{2}=0.01, b=2.18, t=1.76, p=0.08$. Follow up simple slope analyses (Preacher et al., 2006) showed that depressive symptoms did not differ between concussion incidences at low levels of dysfunctional attitudes (Figure 13). However, depressive symptoms were significantly higher with high levels of dysfunctional attitudes in those who reported a history of concussion $(p<0.0001)$ and those who did not $(p<$ 0.0001). However, considering the interaction trend reported above, depressive symptoms were higher for those who reported a concussion and had high dysfunctional attitudes compared to those that did not. 


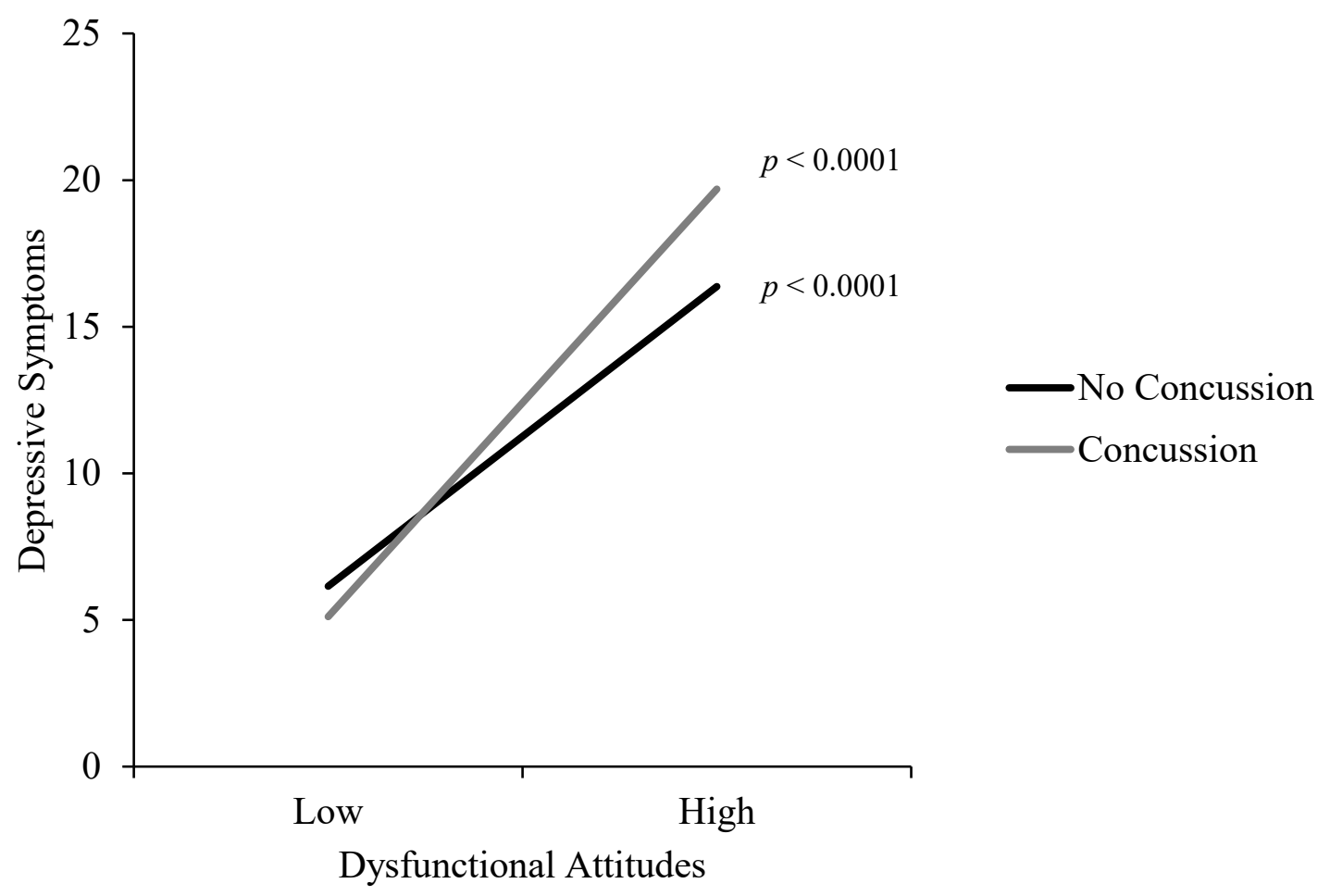

Figure 13. The relation between dysfunctional attitudes and depression scores as a function of concussive injury in females. There was a trend level interaction between dysfunctional attitudes and concussion incidence in females. Follow up simple slope analyses revealed that subjects with high dysfunctional attitudes reported higher depressive symptoms. There was a trend for those who reported a history of concussion and showed high dysfunctional attitudes to report increased depressive symptoms compared to those without a history of concussion.

For males, there was no moderating role of concussion incidence on the relation between dysfunctional attitudes and depression, $\Delta R^{2}=0.003, b=0.96, t=0.72, p=0.47$. Follow up simple slope analyses (Preacher et al., 2006) revealed that depressive symptoms 
did not differ between concussion incidences with low levels of dysfunctional attitudes. However, depressive symptoms were significantly higher with high levels of dysfunctional attitudes for those who reported a history of concussion $(p<0.01)$ and those who did not $(p<0.005)$ (Figure 14).

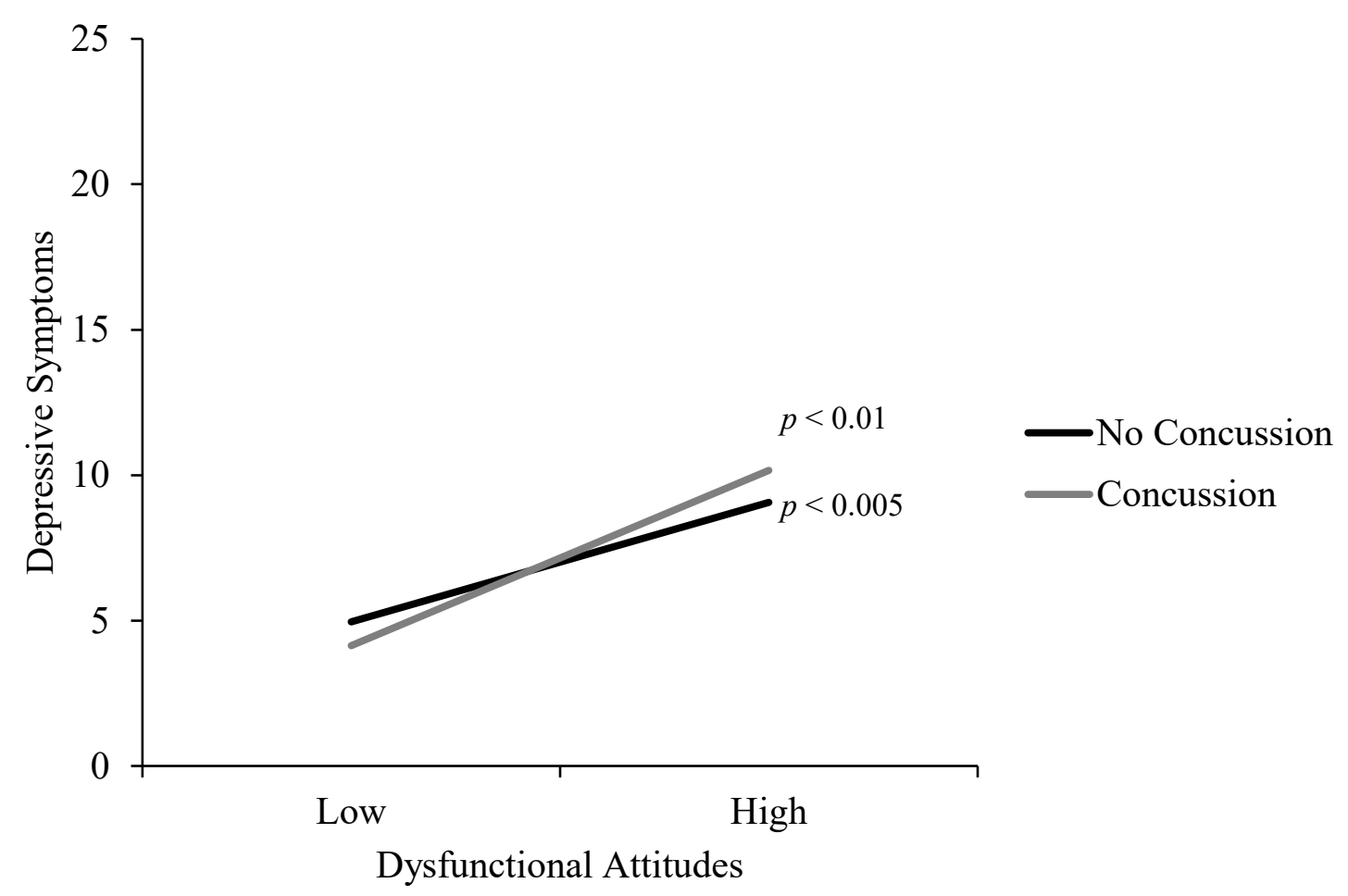

Figure 14. The relation between dysfunctional attitudes and depression scores as a function of concussive injury in males. Simple slopes analyses revealed that concussion groups did not differ in terms of depressive symptoms with low dysfunctional attitudes. However, depressive symptoms were significantly elevated when high levels of dysfunctional attitudes were reported.

Perseverative Errors

To examine the interaction between perseverative errors and depressive symptoms with respect to concussion incidence, separate hierarchical linear regressions were 
conducted for each gender. Perseverative errors and concussion incidence were entered on the first step and the interaction between perseverative errors and concussion incidence was entered on the second. For females, the moderating role of concussion incidence on the relation between perseverative errors and depression was significant, $\Delta R^{2}=0.02, b=3.90$, $t=1.97, p=0.05$. Follow up simple slope analyses (Preacher et al., 2006) revealed that with or without a history of concussion, depressive symptoms did not differ with low levels of perseverative errors (Figure 15). With a history of concussion, depressive symptoms were significantly elevated when there were high levels of perseverative errors $(p<0.05)$, which was not observed in those without a history of concussion ( $p=0.79)$.

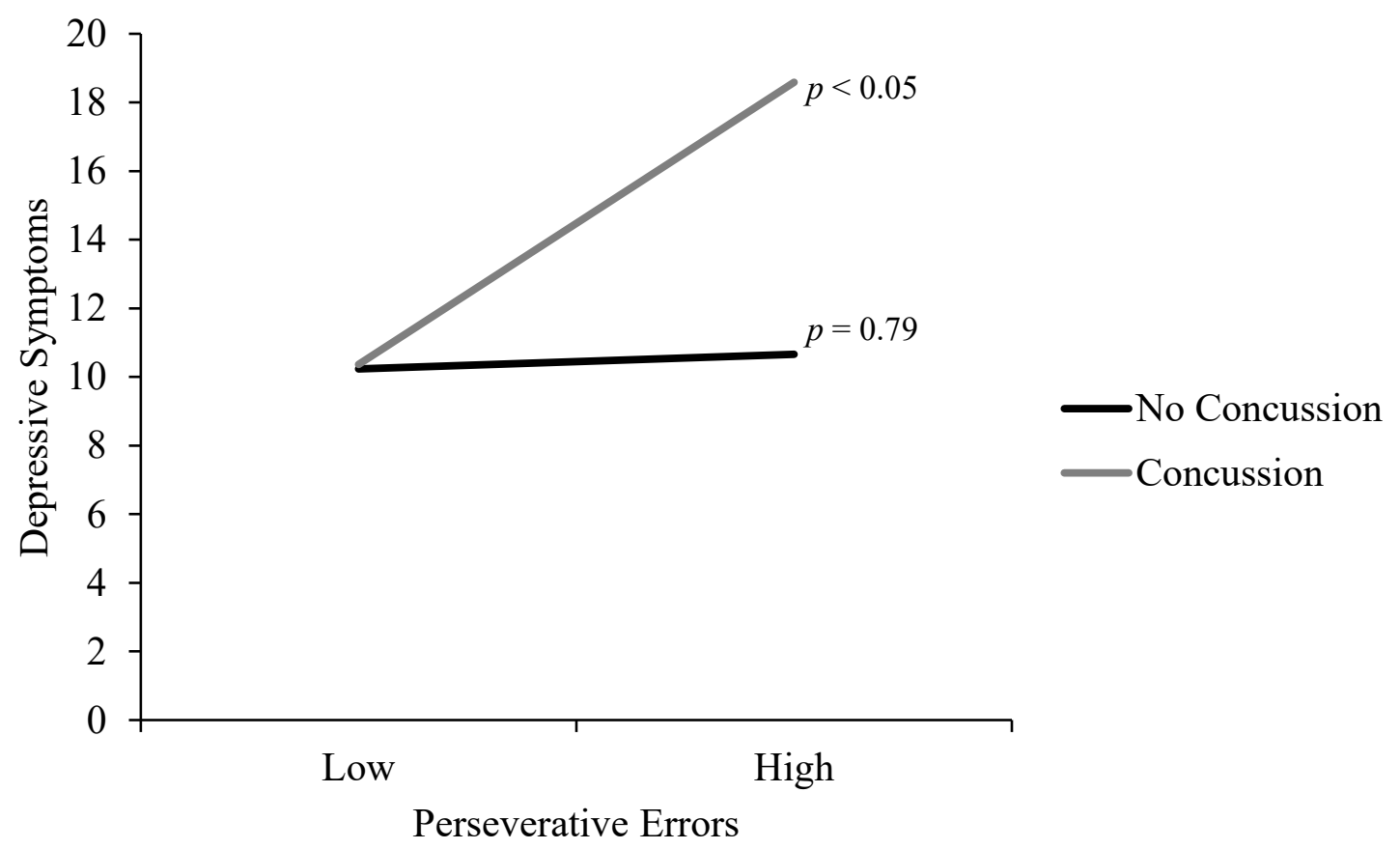

\section{Figure 15. The relation between perseverative errors and depressive symptom} scores as a function of concussive injury in females. There was a significant interaction between perseverative errors and concussion incidence in females. Follow up simple slopes analyses revealed that concussion groups did not differ in depressive symptom 
reporting at low perseverative errors. Depressive symptoms were significantly higher with high levels of perseverative errors, but only in those that had a history of concussion.

For males, the moderating role of concussion incidence on the relation between perseverative errors and depression was not significant, $\Delta R^{2}=0.001, b=-0.55, t=-0.36, p$ $=0.72$. Follow up simple slope analyses (Preacher et al., 2006) showed that in those with or without a history of concussion, depressive symptoms did not differ at low levels of perseverative errors (Figure 16). Simple slopes analyses revealed that males with a concussion history $(p=0.77)$ and males without a concussion history $(p=0.18)$ did not differ in depressive symptoms at low or high perseverative errors.

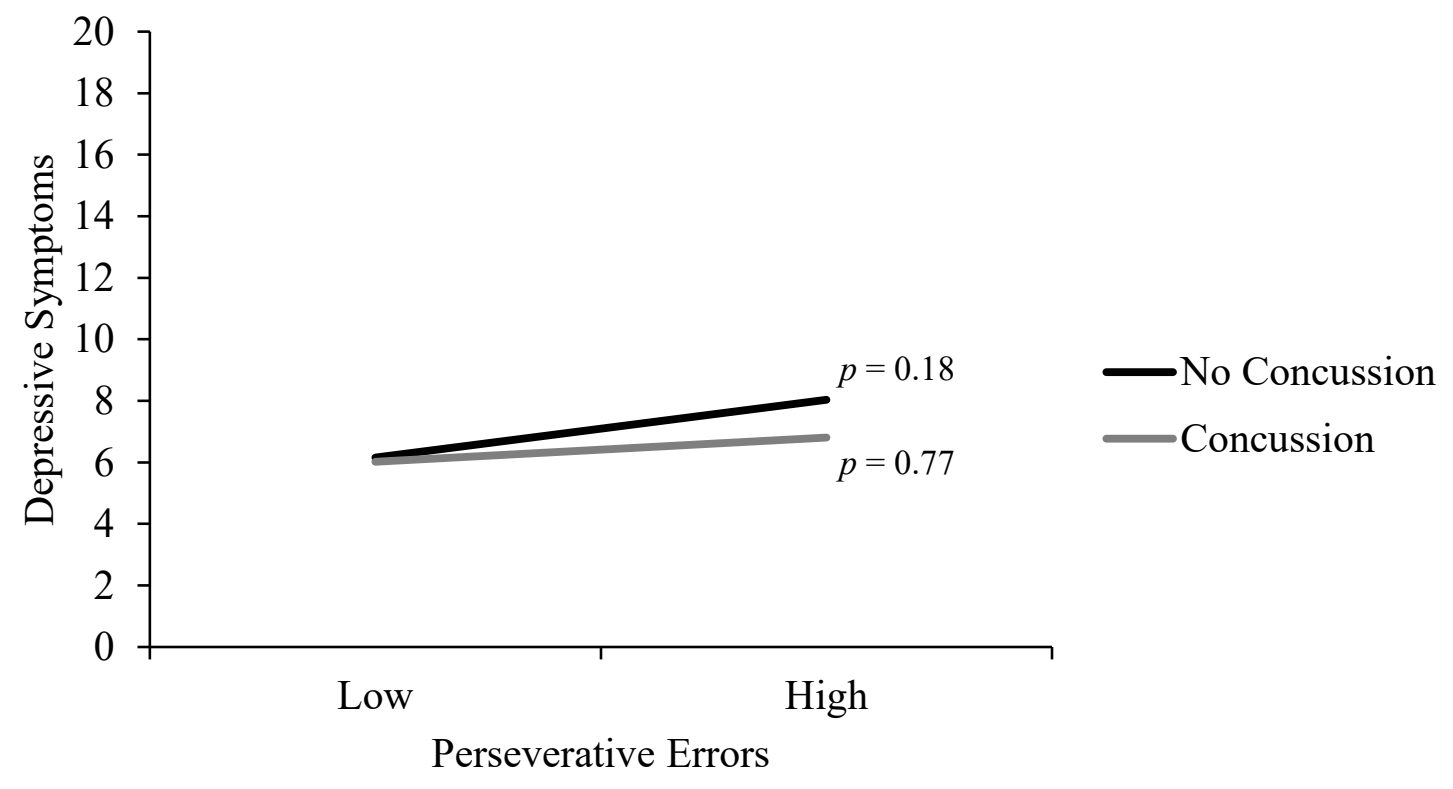

Figure 16. The relation between perseverative errors and depressive symptom scores as a function of concussive injury in males. Simple slopes analyses revealed that concussion groups did not differ at low or high perseverative errors in their reported depressive symptoms. 
Genetic contribution to depressive symptoms in Caucasian male and female students with a history of concussion

It was of interest to determine whether any of the DRD2 C957T, BDNF Val66Met, or COMT Val158Met genotypes were related to depressive scores in the Caucasian sample with or without a history of concussion incidence. Considering the gender differences reported in the above results, separate genotype analyses were conducted on males and females. Within the Caucasian sample, there were no differences on depressive scores based on concussion incidence for females, $F(1,74)=3.554, p=0.063$, or males, $F(1,79)=1.570, p$ $=0.214$.

DRD2 C957T

There were no differences in depressive scores between DRD2 C957T genotypes in all females, $F(2,71)=1.754, p=0.18$, and females with a history of concussion, $F(2,28)=$ 2.43, $p=0.11$ (Table 6). There was a significant difference in depressive scores between DRD2 C957T genotypes in females without a history of concussion, $F(2,40)=3.27, p=0.05$ (Table 6). Tukey HSD post-hoc tests revealed that females with the CC genotype reported significantly more depressive symptoms than the TC genotype, $p=0.04$ (Figure 17) but not the TT genotype, $p=0.11$.

A MANOVA revealed that depressive symptoms varied as a function of the DRD2 C957T genotype $\mathrm{X}$ concussion incidence interaction in females, $F(2,68)=4.04, p=0.02$. Follow-up tests confirmed that in the participants reporting a history of concussion, compared to those without a history of concussion, depression scores were higher among those carrying the TC genotype, $F(1,34)=10.962, p=0.002$ (Figure 17). There were no significant differences in depression scores between those that reported and those that did 
not report a concussion for the TT genotype, $F(1,23) p 0.07, p=0.798$, or the CC genotype, $F(1,11)=0.737, p=0.41$.

Table 6. Mean depressive symptom scores by DRD2 C957T genotype for all females, females with a concussion history, and females without a history of concussion.

\begin{tabular}{lllll}
\hline \multicolumn{5}{c}{ Mean Depressive Symptom Scores } \\
\hline \multirow{2}{*}{ Total } & TT & TC & CC & $p$ \\
Concussion & 7.52 & 10.05 & 12.38 & 0.18 \\
No concussion & 7.00 & 14.38 & 10.17 & 0.11 \\
\hline
\end{tabular}




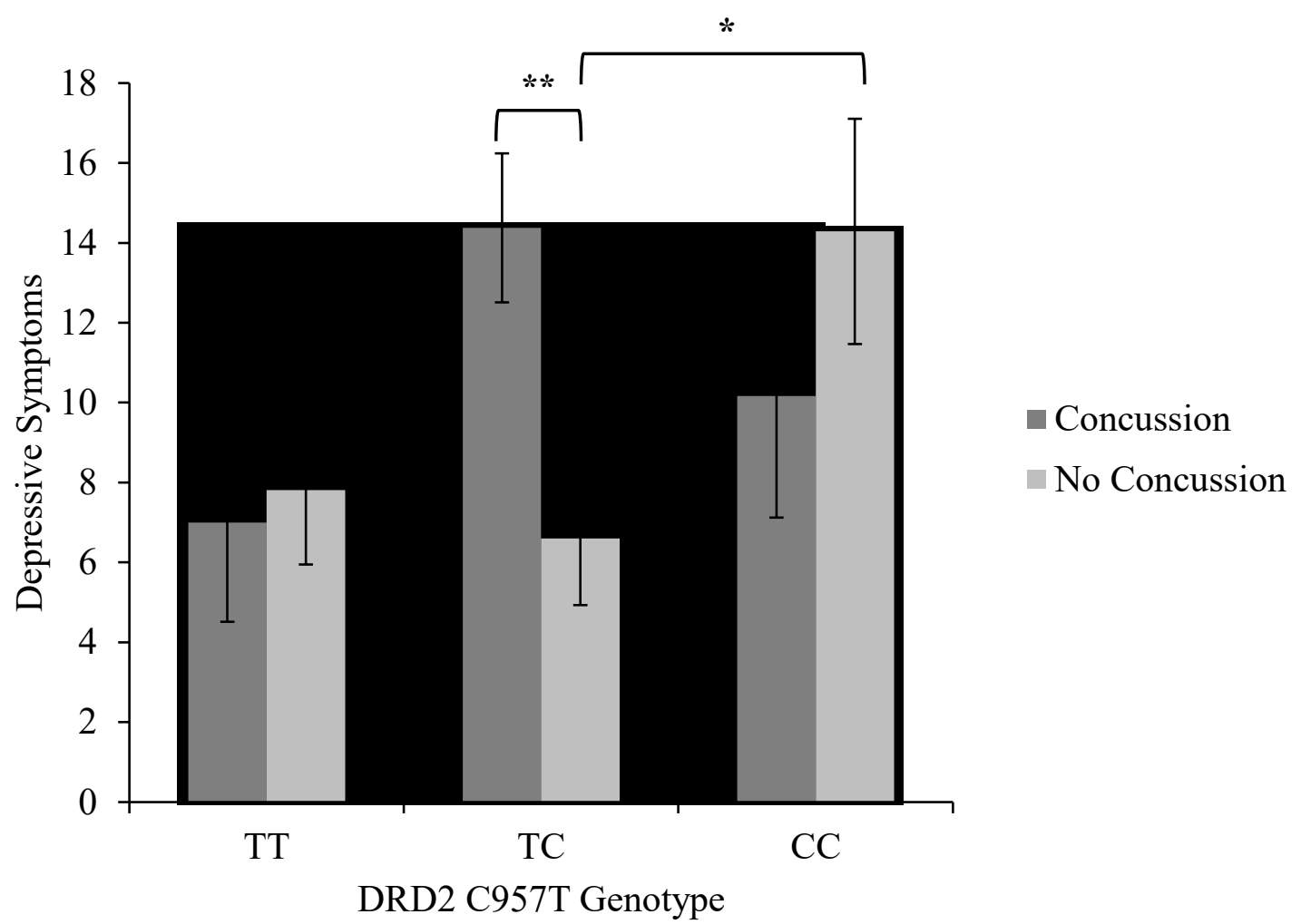

Figure 17. Changes in depressive symptom score as a function of reported concussion incidence and DRD2 C957T genotype in females. Those with the TC genotype who reported a history of concussion had significantly more depressive symptoms than those that did not report a history of concussion. Within those that did not report a history of concussion, females with the CC genotype reported significantly more depressive symptoms than those with the TC genotype. ${ }^{*} p<0.05,{ }^{* *} p<0.01$

In males, there was no difference in depressive scores between DRD2 C957T genotypes for all males, $F(2,67)=0.539, p=0.59$, males with a history of concussion, $F(2$, 28) $=0.76, p=0.48$, and males without a history of concussion, $F(2,36)=0.08, p=0.92$ 
(Table 7). A MANOVA revealed that there was no interaction between the DRD2 genotype and concussion incidence interaction, $F(2,64)=0.04, p=0.96$ (Figure 18).

Table 7. Mean depressive symptom scores by DRD2 C957T genotype for all males, males with a concussion history, and males without a history of concussion.

\begin{tabular}{lllll}
\hline & \multicolumn{4}{c}{ Mean Depressive Symptom Scores } \\
\hline \multirow{3}{*}{ Total } & TT & TC & CC & $p$ \\
Concussion & 5.87 & 7.70 & 7.25 & 0.59 \\
No concussion & 4.75 & 7.00 & 5.67 & 0.48 \\
\hline
\end{tabular}




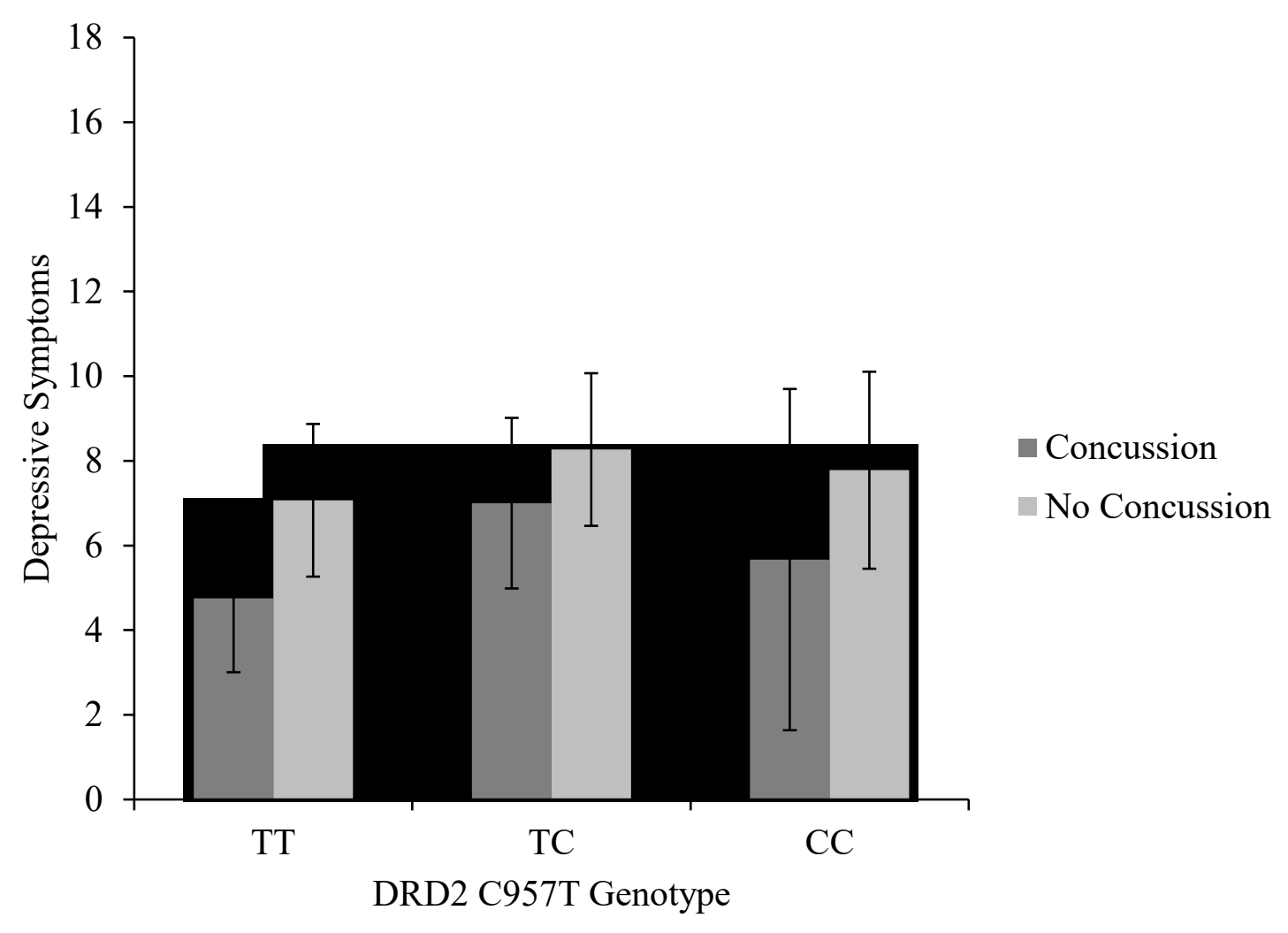

Figure 18. Changes in depressive symptom score as a function of reported concussion incidence and DRD2 C957T genotype in males. There were no significant differences in depressive symptoms based on concussion incidence for any genotypes.

COMT Val158Met

The COMT Val ${ }^{158}$ Met genotypes were also evaluated with respect to depressive scores as a function of concussion incidence. There were no differences in depressive scores between COMT genotypes for all females, $F(2,69)=0.059, p=0.942$, females with a history of concussion $F(2,27)=0.13, p=0.88$, and females without a history of concussion, $F=(2,39)=0.18, p=0.84$ (Table 8). A MANOVA revealed that there was no interaction between COMT genotypes and concussion incidence, $F(2,66)=0.135, p=0.874$ (Figure 19). 
Table 8. Mean depressive symptom scores COMT Val158Met genotype for all females, females with a concussion history, and females without a history of concussion.

\begin{tabular}{lllll}
\hline & \multicolumn{4}{c}{ Mean Depressive Symptom Scores } \\
\hline Total & GG & GA & AA & $p$ \\
Concussion & 9.89 & 9.50 & 8.93 & 0.94 \\
No concussion & 13.20 & 11.05 & 12.17 & 0.88 \\
\hline
\end{tabular}

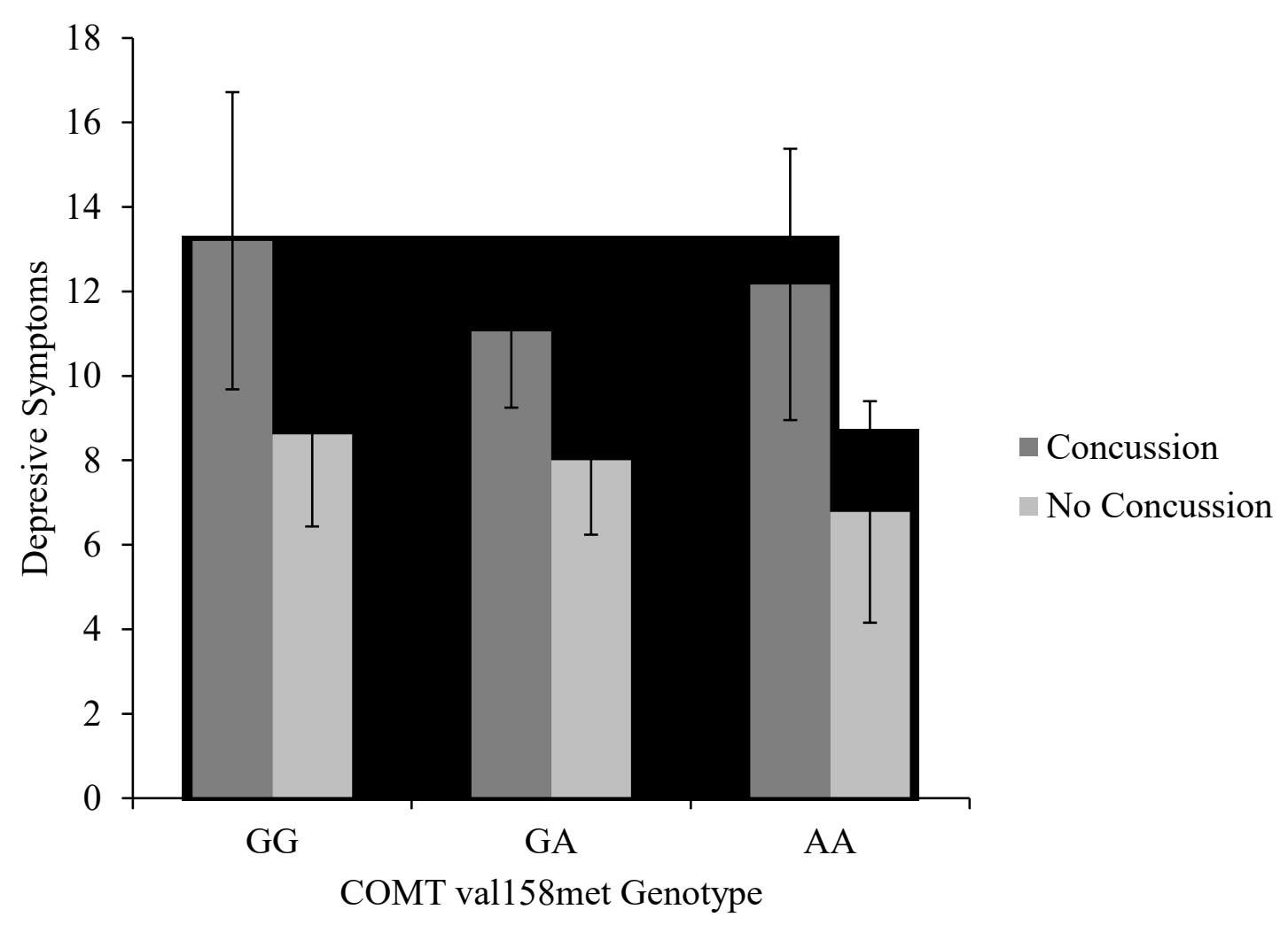

Figure 19. Changes in depressive symptom score as a function of reported concussion incidence and COMT val158me genotype in females. There were no significant differences in depressive symptoms based on concussion incidence for any genotypes. 
There was also no difference in depressive scores between COMT Val ${ }^{158} \mathrm{Met}$ genotypes in all males, $F(2,68)=0.656, p=0.52$, males who have a history of concussion, $F$ $(2,29)=2.39, p=0.11$, and males that did not have a history of concussion, $F(2,36)=2.52$, $p=0.09$ (Table 9). A MANOVA revealed that there was a significant interaction between the Val158Met genotype and concussion incidence, $F(2,65)=4.22, p=0.02$. Follow-up tests revealed that there was a trend toward elevated depressive symptoms among males with the GG genotype who did not report a history of concussion compared to those that did report a history of concussion, $F(1,17)=3.51, p=0.08$ (Figure 20). There were no significant differences in depression scores for those that reported a concussion and those that did not for the GA genotype, $F(1,35)=1.76, p=0.19$, or the AA genotype, $F(1,13)=$ $2.75, p=0.12$.

Table 9. Mean depressive symptom scores COMT Val158Met genotype for all males, males with a concussion history, and males without a history of concussion.

\begin{tabular}{lllll}
\hline \multicolumn{4}{c}{ Mean Depressive Symptom Scores } \\
\hline GG & GA & AA & $p$ \\
Total & 7.89 & 5.86 & 7.47 & 0.52 \\
Concussion & 2.83 & 7.00 & 4.14 & 0.11 \\
No concussion & 10.23 & 4.67 & 10.38 & 0.09 \\
\hline
\end{tabular}




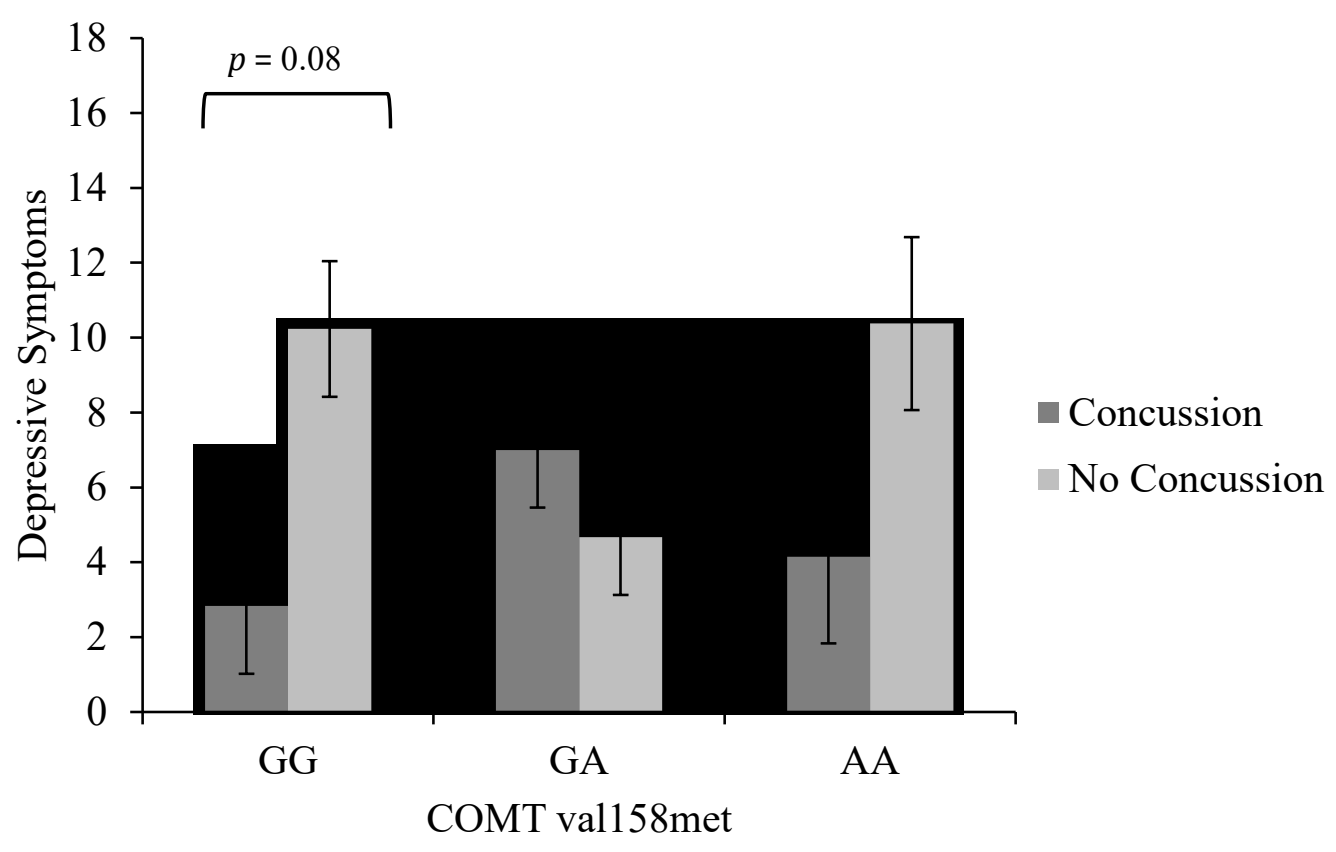

Figure 20. Changes in depressive symptom score as a function of reported concussion incidence and COMT Val ${ }^{158}$ Met genotype in males. Those with the GG genotype who did not report a history of concussion showed more depressive symptoms than those without a concussion history.

BDNF Val66 Met

It was also of interest to determine if the BDNF Val ${ }^{66} \mathrm{Met}$ genotypes predicted depressive scores as a function of concussion incidence. In females, there were no participants with the AA genotype and therefore, only the GG and GA genotypes were compared. There was no difference in depressive scores between GG and GA BDNF Val ${ }^{66}$ Met genotypes in all females, $F(1,71)=0.06, p=0.80$, females with a history of concussion, $F(1,29)=0.03, p=0.87$, and females without a history of concussion, $F(1,40)$ $=0.06, p=0.81$ (Table 10). A MANOVA revealed that there was no interaction between the BDNF genotype and concussion incidence, $F(1,69)=0.00, p=0.99$ (Figure 21). 
Table 10. Mean depressive symptom scores by BDNF Val ${ }^{66}$ Met genotype for all females, females with a concussion history, and females without a history of concussion.

\begin{tabular}{lllll}
\hline \multicolumn{5}{c}{ Mean Depressive Symptom Scores } \\
\hline \multirow{2}{*}{ Total } & GG & GA & AA & $p$ \\
Concussion & 9.14 & 9.63 & N/A & 0.80 \\
No concussion & 11.24 & 11.80 & N/A & 0.87 \\
\hline
\end{tabular}

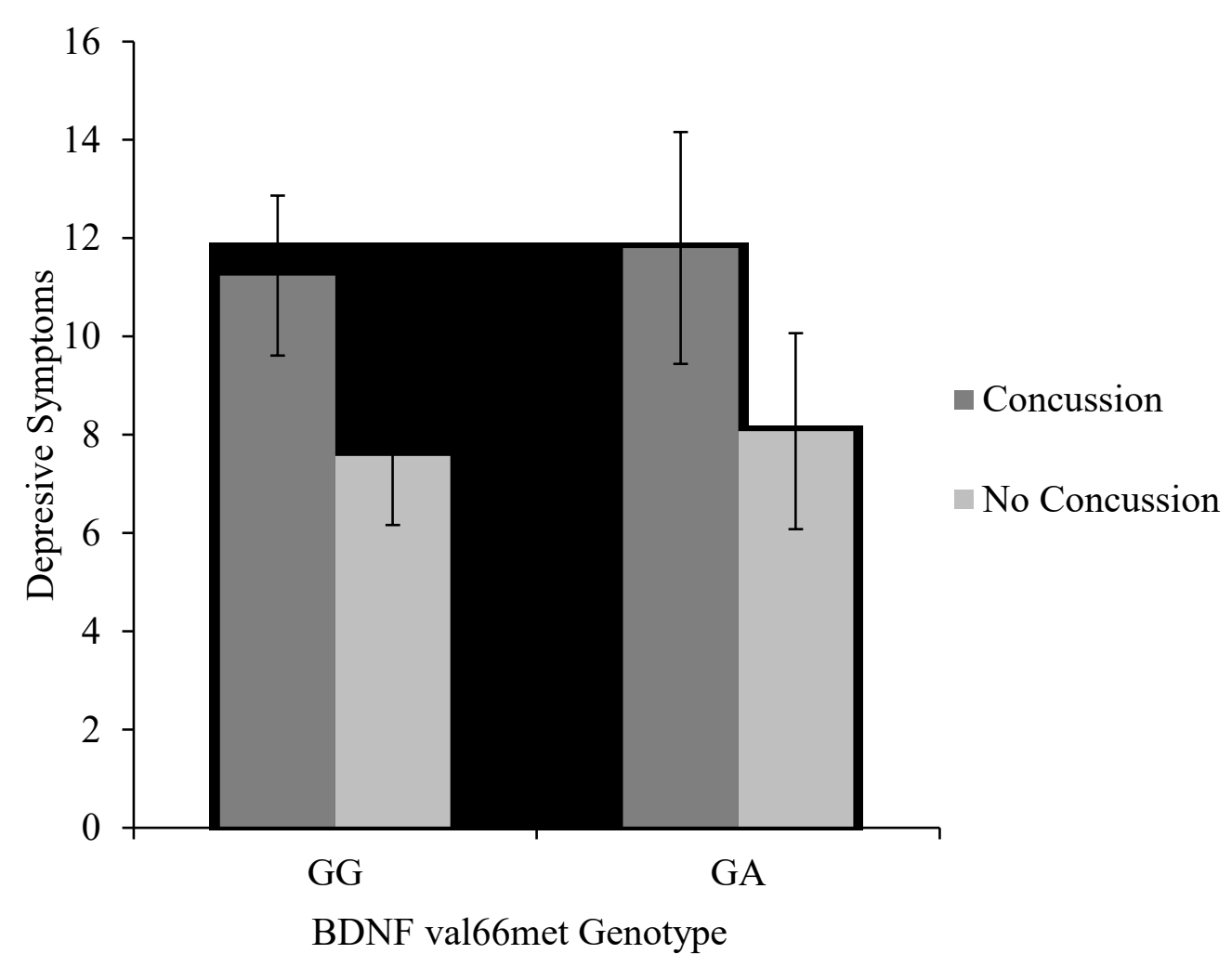

Figure 21. Changes in depressive symptom score as a function of reported concussion incidence and BDNF Val ${ }^{66}$ Met genotype in females. There were no significant differences in depressive symptoms based on concussion incidence for any genotypes. 
There were no differences in depressive scores between BDNF Val ${ }^{66}$ Met genotypes for all males, $F(2,69)=0.71, p=0.50$, males with a history of concussion, $F(2,30)=0.01, p$ $=0.99$, and males without a history of concussion $F(1,37)=1.73, p=0.20$ (Table 11). A MANOVA revealed that there was no interaction between the BDNF Val ${ }^{66} \mathrm{Met}$ genotype and concussion incidence, $F(1,67)=1.07, p=0.30$ (Figure 22).

Table 11. Mean depressive symptom scores by BDNF Val66Met genotype for all males, males with a concussion history, and males without a history of concussion.

\section{Mean Depressive Symptom Scores}

\begin{tabular}{lllll}
\hline & GG & GA & AA & $p$ \\
Total & 7.37 & 5.30 & 5.00 & 0.50 \\
Concussion & 5.70 & 5.67 & 5.00 & 0.99 \\
No concussion & 8.75 & 5.00 & N/A & 0.20 \\
\hline
\end{tabular}




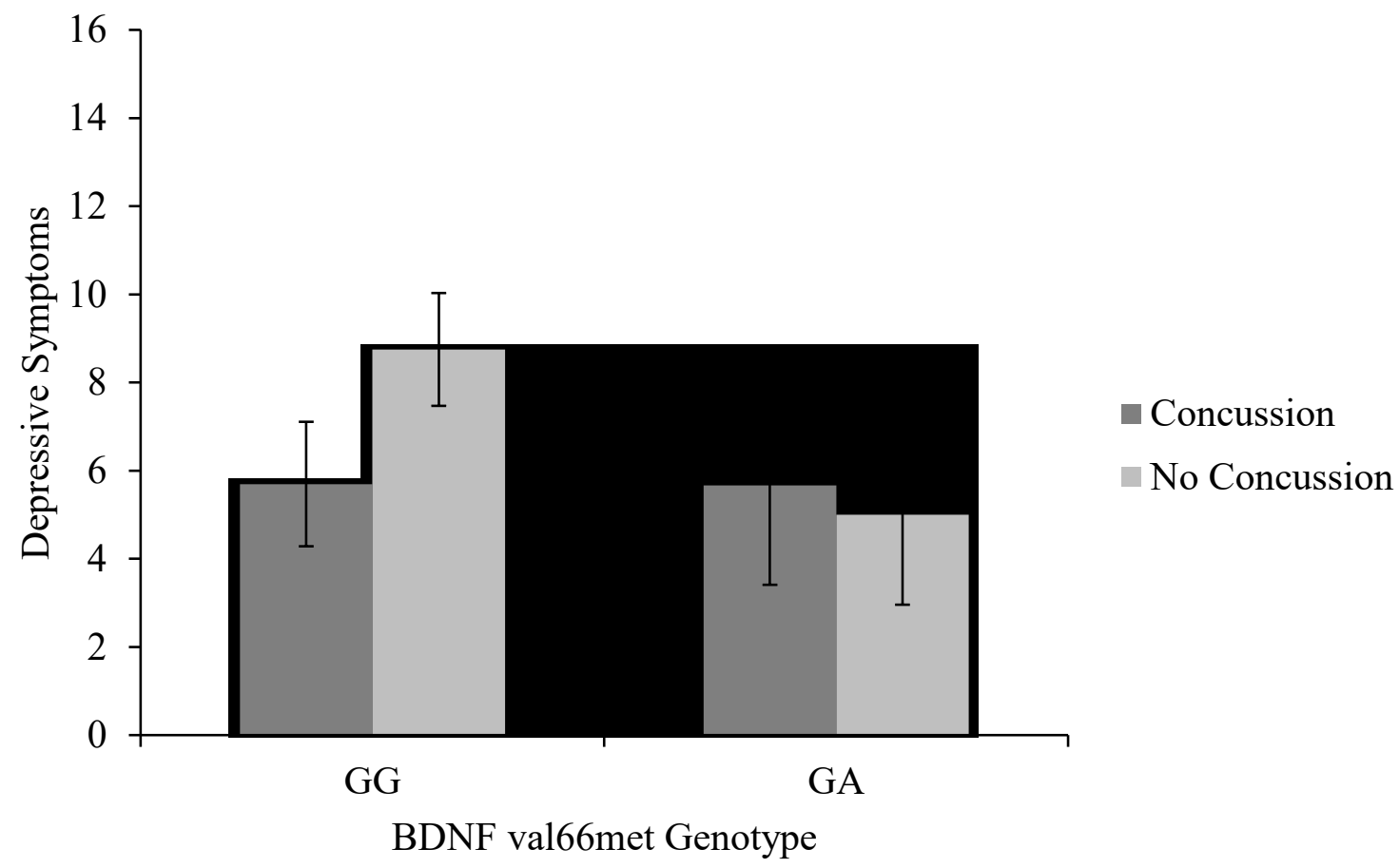

Figure 22. Changes in depressive symptom score as a function of reported concussion incidence and BDNF Val ${ }^{66}$ Met genotype in males. There were no significant differences in depressive symptoms based on concussion incidence for any genotypes. 


\section{Discussion}

Those who have suffered a concussion commonly report depressive symptoms. Although a number of vulnerability factors have been explored, it is still unclear why only some people have long-lasting depressive symptoms following a concussion. The present study revealed that gender, early life adversity, dysfunctional attitudes, and executive functioning are factors that influence the strength of the relationship between concussive incidence and depression. Genetic polymorphisms of the DRD2 gene also were found to contribute to the relationship between concussion and depressive symptoms in Caucasian females.

Experiential and Cognitive Contribution to Depressive Symptoms in Male and Female Students with a History of Concussion

\section{Gender Difference}

The results of this study support the hypothesis that a history of concussion is associated with elevated depressive symptoms. However, this relationship was only true for females as there was no association revealed between concussion incidence and depressive symptoms in males. Although there is a dearth of concussion studies with female participants, the present findings are consistent with the concussion literature whereby females present worse psychological outcomes following concussive injuries. For example, some studies have reported that females are more prone to neuropsychological and cognitive deficits following concussion (Covassin et al., 2012; Dougan et al., 2014). Elevated post-concussive dysfunction in females has been attributed to an increased metabolic demand, thus resulting in increased damage following the metabolic cascade 
associated with a concussion (Andreason et al., 1994; Giza and Hovda, 2001; Broshek et al., 2005).

It is also not surprising that depressive symptoms were increased in females with a concussion as the rate of depression is much higher among females in the general population (Ferrari et al., 2013), which was also true for the sample used in the present study. It is possible that premorbid depression predisposed individuals to present more post-concussive depressive symptoms (Vargas et al., 2015). Since no baseline measures of depression were collected, this cannot be assessed in the present work.

\section{Physical Trauma}

It has been reliably found that those who experience trauma during childhood, such as physical abuse, have an increased risk of developing depression later in life (Mandelli et al., 2015). However, it is not known whether those who experience trauma early in life and then experience a concussion show potentiated levels of depressive symptoms. The present study revealed that physical trauma and concussion incidence interacted to predict

depressive symptoms in females. Interestingly, only females who did not report a history of concussion had elevated depressive symptoms with high physical trauma. In females who did report a history of concussion, depressive symptoms were elevated, but did not differ based on physical trauma experienced.

van Veldhoven and colleagues (2011) also reported an interaction between stressful life experiences and concussion on post-concussive symptoms, but in their study those who experienced stressful life experiences (mainly physical and sexual abuse) combined with concussion history had significantly elevated post-concussive symptoms. The authors attributed this finding to either an impaired ability to deal with the stressor of a concussion 
due to pre-injury stress or the concussion exacerbating a pre-existing disorder associated with the pre-injury stress (van Veldhoven et al., 2011). This is consistent with a sensitization hypothesis mentioned by Rathbone et al (2015), where an individual who has been exposed to a significant stressor before concussion may be sensitized to a greater inflammatory response following the injury.

Stressful experiences during development are suggested to cause physiological changes of the frontal cortex and limbic structures (Lupien et al., 2009), leading to poor executive functions (Zhao et al., 2015) and depression (Mandelli et al., 2015). The physiological changes within the frontal cortex may lead to sensitization of the brain to further stress (such as a concussion) through altered mineralocorticoid/ glucocorticoid receptor balance (Baes et al., 2014). Therefore, it was hypothesized that when history of trauma and concussive injury were both present, they would interact to produce exacerbated depressive symptoms.

The present findings, where depressive symptoms were uniform for females who reported a history of concussion, regardless of physical trauma experienced, were not expected. It is possible that having a concussion does not impact pre-frontal function in a similar fashion as physical trauma, and therefore the two do not lead to a synergistic effect. Physiological changes after childhood adversity are suggested to occur through activation of the HPA axis and high levels of glucocorticoids (Lupien et al., 2009; Goel et al., 2014), where changes after concussion are suggested to occur through cytokines and inflammatory processes (Patterson and Holahan, 2012). Therefore, it is possible that both high physical trauma and concussion incidences contribute to depressive symptoms via separate mechanisms that may not overlap. 


\section{Physical Trauma Experienced During Different Ages}

It was of interest to dissect physical trauma experienced at different ages to examine whether concussion interacted with trauma experienced during different developmental periods. Stress has been shown to have a significant effect on the brain when experienced during in utero development, childhood, during adulthood, and into aging (Lupien et al., 2009). Studies have reported elevated HPA axis activity in children born to mothers stressed during pregnancy (O'Connor et al., 2005). In early life, adversity or parental deprivation has been associated with epigenetic changes in glucocorticoid receptors, impacting the negative feedback of the HPA axis, and elevated cortisol levels (McGowan et al., 2009). Studies have shown that the HPA axis shows a heightened response to stress in adolescence and is more active overall, even in times of no stress (Gunnar et al., 2009). Since the frontal cortex undergoes a heightened amount of development throughout adolescence (Lupien et al., 2009), it is particularly vulnerable to the negative consequences of stress during this time (Cohen et al., 2006). The impacts of childhood abuse are evident into adulthood, through elevated levels of ACTH, indicating heightened HPA axis activity (Heim et al., 2000). Due to the negative impacts of stress throughout development, it was hypothesized that someone who experienced high physical trauma at any age and reported a history of concussion would report elevated depressive symptoms.

The results from the present study suggested that physical trauma experienced between the ages of 6 and 12 interacted with the incidence of concussion to predict depressive symptoms in females, and that this interaction is present (although not significantly) for physical trauma experienced throughout early life (i.e. 0 - 5, 13-18, 18+). 
However, the results were not as predicted since females who reported a concussion had elevated depressive scores that did not change based on physical trauma experienced, and therefore the effects were not synergistic. It is possible that an additive effect would be seen if these participants were questioned at an older age. The frontal lobe, which seems to be impacted by childhood stress (Cohen et al., 2006), is particularly sensitive to glucocorticoids at an older age (Dai et al., 2004). Therefore, if a concussion is experienced, contributing to damage of the frontal lobes and cognitive deficits (Chen et al., 2008b), and the HPA axis is hyperactive throughout adulthood due to a childhood trauma, when the individual reaches older adulthood, they could be at a increased risk to negative consequences like depression.

\section{Dysfunctional Attitudes}

Dysfunctional attitudes are negative maladaptive schemas that become apparent after exposure to a stressful life event (Beck, 1967). These negative schemas disrupt the ability for a person to disengage from negative stimuli and impair their ability to attend to positive information, indicating that cognitive control is impaired (Disner et al., 2011). This is particularly maladaptive when one is dealing with subsequent stressors (You et al., 2009), such as returning to school or work after a concussion. Thus, it was hypothesized that someone with dysfunctional attitudes might have an elevated vulnerability to depressive symptoms after a concussion.

The present findings support this hypothesis as depressive symptoms were particularly elevated in females who reported high dysfunctional attitudes and a history of concussion. Although this finding was a trend, it would be interesting to determine whether this effect remained in a longitudinal study. Since the participants were 19 years of age, it 
does not allow for a full analysis of the impact of this effect when life stressors become more serious. Therefore, if an individual with dysfunctional attitudes suffers a concussion, their depressive symptoms may become more prominent later in life when they have to deal with more profound life events (e.g., relocation, finances, personal health). Furthermore, dysfunctional attitudes may indicate that there are deficits in areas of the PFC, such as the VLPFC and DLPFC, that are responsible for maintaining proper attentional control (Kastner et al., 1998; Disner et al., 2011), and that bottom up control is favoured. As these cognitive and functional issues are similar to those seen in concussed individuals (Ellemberg et al., 2007; Chen et al., 2008b), those with dysfunctional attitudes may be at higher risk for an imbalance between prefrontal inhibition and limbic activation, that can lead to the development and maintenance of depressive symptoms (Disner et al., 2011). Although dysfunctional attitudes tend to not vary between genders (You et al., 2009), and did not vary in the present study, dysfunctional attitudes may be more damaging to females who suffer a concussion compared to males. For one, the HPA axis in females appears to be more reactive to stressors (Gerra et al., 1992; Jezová et al., 1994; Goel et al., 2014). Since dysfunctional attitudes tend to emerge after a stressor (Beck, 1967; You et al., 2009), they may be more frequently activated in females who have suffered a concussion. Furthermore, females may have a greater energy deficit following a concussion (Giza and Hovda, 2001), and therefore, their brains may remain more vulnerable to subsequent insults. Since dysfunctional attitudes may occur at a higher frequency after a concussion and the metabolic damage may be worse, females with dysfunctional attitudes and a concussion may be particularly vulnerable to long-term symptoms, especially depression. 


\section{Executive Functioning}

Deficits in executive functioning are often an outcome following a concussion and associated with depressive symptoms (Ellemberg et al., 2007; Disner et al., 2011). However, the relationship between executive function and concussion incidence as predictors of depressive symptoms has not been studied. The results of this study revealed that deficits in executive functioning, particularly poor set shifting, interacted with concussion incidence to predict elevated depressive symptoms in females. These results are consistent with other literature reporting depressive symptoms, as well as other postconcussive symptoms, were associated with poor executive functioning after injury (Sterr et al., 2006).

Perseverative errors have specifically been shown to be a significant predictor of depression severity in MDD patients (Withall et al., 2009). Perseveration represents an inability to discontinue a previous response, and therefore may be an indicator that one has difficulty shifting from one stimuli to another (Withall et al., 2009; Disner et al., 2011). An inability to switch to relevant stimuli may contribute to the emergence and maintenance of a depressive state as it constantly exposes one to negative stimuli and makes daily tasks difficult to complete (Disner et al., 2011). Furthermore, biased attention to negative stimuli in MDD has been associated with pre-frontal dysfunction, such as hypoactivity in the PFC, indicating lack of top-down control over limbic regions (Grimm et al., 2008).

Concussions lead to frontal lobe dysfunction, as shown by executive function deficits (Ellemberg et al., 2007), differences in PFC activity in functional imaging studies (Slobounov et al., 2010; Dettwiler et al., 2014), and reduced medial frontal gray matter 
density (Chen et al., 2008b). The frontal lobe dysfunction seen after concussion may contribute to depressive symptoms, as the individual may have a hard time completing everyday tasks and focusing on relevant stimuli (Disner et al., 2011). The damage of this circuit could be particularly true for females, as their risk of damage after the metabolic cascade is thought to be elevated compared to males (Broshek et al., 2005).

Genetic contribution to depressive symptoms in Caucasian male and female students with a history of concussion

Post-concussion depressive symptoms may be associated with poor prefrontal functioning, especially in females. This may lead to poor top-down control by the PFC, increasing vulnerability to depression. As a way to further explore the biological underpinnings of the vulnerability to the development of depression after a concussion, it was of interest to look at SNPs that have been associated with cognitive function and depressive pathology, as they may be involved in prefrontal dysfunction following concussion.

DRD2 C957T

Elevated depressive symptoms were seen in females heterozygous for the DRD2 C957T (rs6277) polymorphism, but only if they reported a history of concussion. In vitro, the mRNA of the DRD2 gene is less stable when the T allele is present and thus the expression of the gene is diminished (Duan et al., 2003). In vivo, human positron emission tomography (PET) studies have reported that this SNP alters the binding potential of D2 receptors in the brain, as $\mathrm{CC}$ carriers have the lowest binding potential in the striatum but the highest potential in the cortex and thalamus compared to those with the TT genotype 
(Hirvonen et al., 2004, 2009b). Therefore, the present study suggests that the binding potential of the D2 receptor, particularly intermediate levels of binding, might be important in the post-concussion depressive symptoms in females.

The present findings are interesting as the $\mathrm{C}$ allele of the $\mathrm{C} 957 \mathrm{~T}$ polymorphism has been associated with poor performance on the WCST and disorders, such as schizophrenia, where deficits in executive functions are prominent (Lumme et al., 2007; Xu et al., 2007; Monakhov et al., 2008). It is possible that females heterozygous for C957T have preexisting poor executive functions, which become exacerbated following a concussion, thereby increasing depressive symptomology.

It is curious that the CC carriers did not also report an increase in depressive symptoms when a history of concussion was reported. This may be explained by the differences in binding potential within different brain regions (Hirvonen et al., 2009b). However, studies assessing the influence of the C957T SNP on binding potential have not been well investigated in females and therefore it is hard to draw comparisons with previous findings.

Similar to previous results, significant differences for DRD2 C957T X concussion incidence were only seen in female participants. This difference may be attributed to gender disparities in executive functioning following concussion, as cognitive deficits are observed following concussive injuries, especially in females (Covassin et al., 2012). Since those who carry the $\mathrm{C}$ allele of the C957T SNP already have poor executive functioning (Lumme et al., 2007), it is possible that these deficits are potentiated by cognitive deficits following concussion. Overall, this poor executive function may make it difficult for females 
to focus on appropriate stimuli or inhibit negative thoughts, thus increasing their vulnerability to depression (Disner et al., 2011).

One study looked at levels of depressive rumination based on C957T genotype in individuals who were diagnosed with depression compared to healthy controls (Whitmer and Gotlib, 2012). The results revealed that depressed individuals with the CC genotype reported significantly higher levels of depressive rumination compared to other genotypes or controls. Whitmer and Gotlib (2012) suggested that individuals with the CC genotype have less tonic stimulation of the D2 receptor in the striatum, which impacts their ability to learn from punishment. Since the D2 receptor is coupled to inhibitory G-proteins, when DA stimulates the receptor, there is an inhibitory response (Whitmer and Gotlib, 2012). However, when DA is not bound or there is a pause in stimulation, which is the case in punishment, the inhibitory response is inhibited, leading to activation. Therefore, the individual is not able to learn from the punishment, since there is less binding of D2 and therefore less inhibition (Whitmer and Gotlib, 2012). However, this study did not take into account the frontal cortex, which not only has D2 receptors, but is also highly implicated in rumination and inhibition (Disner et al., 2011). It may be that in people who have suffered a concussion, or have depression, the amount of prefrontal D2 receptors is diminished, and therefore the binding potential is impacted, leading to less inhibition and more rumination.

\section{COMT Val158Met}

The COMT Val158Met polymorphism was also of interest as it influences both DA levels and DA activity in the PFC, and the Met (A) allele is associated with increased levels of DA in the PFC and better executive functioning (Lachman et al., 1996; Tunbridge et al., 2004; Mandelli et al., 2007; Logue and Gould, 2014; Willmott et al., 2014). In the present 
study, depressive symptoms were not related to COMT Val158Met genotype and there was no interaction between depressive symptoms and genotype in predicting depression in females. However, depressive symptoms were elevated (though not statistically significant) in males with the Val/Val (GG) genotype with no reported history of concussion compared to those that did report a history of concussion.

Presence of the Val/Val genotype is associated with elevated COMT activity and as a result low DA levels in the PFC (Chen et al., 2004). Therefore, the findings in the present study, where the Val/Val genotype was associated with elevated depression, are consistent with findings that showed diminished depressive symptoms in participants given a COMT inhibitor (Fava et al., 1999). It is suggested that executive functions rely on DA activity in the PFC, which is exemplified by poor executive function in individuals with the Val/Val genotype (Tunbridge et al., 2004). Thus, it is possible that cognitive dysfunctions seen in the Val/Val genotype increase the vulnerability to depression in these individuals.

It was hypothesized that individuals with the Val/Val genotype and a history of concussion would have elevated depressive symptoms. The present findings do not support this hypothesis. These findings are contrary to those by Winkler and colleagues (2015), who found the Met allele to be associated with better executive performance compared to the Val allele 6 months after concussive injury. However, Winkler et al (2015) did not include a non-injured control group, and therefore it is possible that the differences in executive function would have existed regardless of concussive injury.

The gender differences reported in this study are similar to those found by White et al 2014, who used an fMRI to examine the differences of the COMT Val158Met genotypes in pre-frontal activity during an inhibition task. Activation of the PFC was only significantly 
elevated in Val/Val males, indicating cortical function was inefficient to complete the task (White et al., 2014). The gender differences are largely attributed to the catabolic effect of estrogen on COMT in females (Xie et al., 1999), thus reducing the variability of $\mathrm{Val}^{158} \mathrm{Met}$ genotypes.

\section{BDNF Val ${ }^{66} \mathrm{Met}$}

Those who carry the A allele, and therefore Met instead of Val, of the BDNF Val ${ }^{66} \mathrm{Met}$ polymorphism have shown an association with an elevated depression risk, differences in prefrontal structure, and reduced executive function after concussion (Pezawas et al., 2004; Verhagen et al., 2010; Lamb et al., 2014; Legge et al., 2015). Significantly elevated deficits in cognitive function have also been reported in Met carriers who experienced a concussion (McAllister et al., 2012). Consequently, it was predicted that Met carriers would have elevated depressive symptoms, especially if they also reported a history of concussion.

The present findings were unexpected, as there were no significant differences in depressive symptoms based on this genotype or interactions with concussion incidence to predict depressive symptoms for males or females. These findings contradict those by McAllister et al (2012) since it was expected that those with the most cognitive dysfunction (i.e. the Met allele and a concussion) would have the most depressive symptoms. However, these significant findings in McAllister et al (2012) were only relevant for one month after injury and therefore it is possible that if timing of injury was assessed in the present study, there may have been a difference in those with a recent injury. The significance of timing by McAllister (2012) suggests that $\mathrm{Val}^{66} \mathrm{Met}$ genotypes may influence how well someone is able to deal with the initial consequences of a concussion but further factors may be important in determining long-term consequences. 
The relationship between the BDNF Val ${ }^{66}$ Met polymorphism and depression has also been found to depend on environmental events (Hosang et al., 2014). Thus, it is also possible that another variable, such as physical trauma, may contribute to this relationship (Verhagen et al., 2010). Someone who experiences a stressful life event may have a reduction in BDNF activity, which may be more deficient in someone with the Met allele at codon 66 of the BDNF gene, thus increasing depressive vulnerability (Hosang et al., 2014). This vulnerability may be further exacerbated by the damage and stress associated with a concussion.

\section{Limitations}

In order to fully understand the results discussed here, it is important to consider some limitations of this study. The sample size of the experiential and cognitive part of this study was quite large $(N=319)$, especially when compared to other similar concussion studies (Vargas et al., 2015). However, the sample sizes became quite small $(N=157)$ when the sample was reduced to include only Caucasian participants, especially when this was then divided by gender, genotypes, and concussion incidence. Not only does this make it difficult to draw firm conclusions based on the gene data, but it was not possible to fully investigate how the genes interacted with other variables. Another limitation with the sample is the participants were taken from an undergraduate population and therefore was comprised of exclusively students between the ages of 17 and 25 . Therefore, the results may not generalize to other populations, particularly children and older adults.

Due to the nature of this research, levels of trauma and concussion incidence were determined through self-report. Although this method is used in many studies, it could be confounded by recall bias (Guskiewicz et al., 2007). Ideally, medical records of the 
participants would have been obtained in order to validate concussion incidence. However, it is common that individuals who suffer a concussion do not seek medical attention and therefore medical records may not exist. Self-report questionnaires were also used to determine psychosocial variables. Although interviews may be more ideal, the scales used had good internal reliability in the present study, and are validated and widely used in others (Richter et al., 1998; Beevers et al., 2007; Bremner et al., 2007; Thompson et al., 2009).

The main objective of this study was to determine predictors of post-concussive depression. Although significant predictors were found, it is not possible to determine if these are causal, as pre-concussion values were not obtained. Additionally, the timing of concussion was not asked. Therefore, it is not possible to determine the impact of concussion timing on depressive symptoms. In the future, it would be ideal to perform this study again as a repeated measure, so that baseline measures can be determined and additional questions about the concussion timing can be explored.

Concussion severity was another variable that was not included in this report. Although severity of the concussion (i.e. a collision followed by loss of consciousness, amnesia) has been hypothesized to predict post-concussion symptom severity, this has not been widely shown (Broshek et al., 2005, 2015; McCrory et al., 2013). A more validated measure of concussion severity, such as the Glasgow Coma Scale, was not used in the present study to include the impact severity. However, participants were asked about symptoms they had immediately following the injury, such as loss of consciousness, amnesia, confusion, and if they received medical care. In the present study, only using concussions that lead to one of the symptoms listed above or medical care was considered 
but this criteria only excluded 2 females and 4 males. Considering the small impact and lack of evidence that severity impacts concussive outcome (McCrory et al., 2013), the yes/no self-report variable was used instead.

\section{Conclusions}

Experiencing a concussion has been associated with depressive symptoms in approximately 17 to $44 \%$ of concussed individuals (Rutherford et al., 1977; Broshek et al., 2015; Solomon et al., 2015). Predictors of who will experience depressive symptoms after concussion have been investigated, but it is still unclear who is at risk. The present study revealed that females are more vulnerable to depressive symptoms following concussion, and that childhood physical trauma, dysfunctional attitudes, and executive functioning also influence this relationship. Furthermore, DA receptor density may influence depression vulnerability in Caucasian females who reported a history of concussion. These results suggest that the concussive injury may interact with previous prefrontal dysfunctions, which increase vulnerability to depression. It would be of interest to carry out this study as a repeated measures design to assess baseline data and to increase the sample size so that gene interactions can be fully explored. It is important to understand vulnerability factors that predispose individuals to experience long-term symptoms following concussions in order to determine who may need extra attention after injury, how to tailor treatments, and as a result improve recovery. 


\section{References}

Andreason PJ, Zametkin AJ, Guo AC, Baldwin P, Cohen RM (1994) Gender-related differences in regional cerebral glucose metabolism in normal volunteers. Psychiatry Res 51:175-183.

Axelrod J, Tomchick R (1958) Enzymatic 0-methylation of epinephrine and other catechols. J Biol Chem 233:702-705.

Baddeley A (2003) Working memory: looking back and looking forward. Nat Rev Neurosci 4:829-839.

Baes C von W, Martins CMS, Tofoli SM de C, Juruena MF (2014) Early Life Stress in Depressive Patients: HPA Axis Response to GR and MR Agonist. Front psychiatry 5:2.

Barker-Collo S, Jones K, Theadom A, Starkey N, Dowell A, McPherson K, Ameratunga S, Dudley M, Te Ao B, Feigin V (2015) Neuropsychological outcome and its correlates in the first year after adult mild traumatic brain injury: A population-based New Zealand study. Brain Inj:1-13.

Beck AT (1967) Depression: Clinical, Experimental, and Theoretical Aspects. University of Pennsylvania Press.

Beck AT, Ward CH, Mendelson M, Mock J, Erbaugh J (1961) An inventory for measuring depression. Arch Gen Psychiatry 4:561-571.

Beevers CG, Strong DR, Meyer B, Pilkonis PA, Miller IW (2007) Efficiently assessing negative cognition in depression: An item response theory analysis of the Dysfunctional Attitude Scale. Psychol Assess 19:199-209.

Bergsneider M, Hovda DA, Lee SM, Kelly DF, McArthur DL, Vespa PM, Lee JH, Huang S-C, Martin NA, Phelps ME, Becker DP (2009) Dissociation of Cerebral Glucose Metabolism and Level of Consciousness During the Period of Metabolic Depression Following Human Traumatic Brain Injury. http://dx.doi.org/101089/neu200017389.

Braver TS, Cohen JD, Nystrom LE, Jonides J, Smith EE, Noll DC (1997) A Parametric Study of Prefrontal Cortex Involvement in Human Working Memory. Neuroimage 5:49-62.

Bremner JD, Bolus R, Mayer EA (2007) Psychometric properties of the Early Trauma Inventory-Self Report. J Nerv Ment Dis 195:211-218.

Broshek DK, De Marco AP, Freeman JR (2015) A review of post-concussion syndrome and psychological factors associated with concussion. Brain Inj 29:228-237. 
Broshek DK, Kaushik T, Freeman JR, Erlanger D, Webbe F, Barth JT (2005) Sex differences in outcome following sports-related concussion. J Neurosurg 102:856-863.

Brunoni AR, Vanderhasselt M-A (2014) Working memory improvement with non-invasive brain stimulation of the dorsolateral prefrontal cortex: A systematic review and metaanalysis. Brain Cogn 86:1-9.

Bush G, Luu P, Posner M (2000) Cognitive and emotional influences in anterior cingulate cortex. Trends Cogn Sci 4:215-222.

Chen J, Lipska BK, Halim N, Ma QD, Matsumoto M, Melhem S, Kolachana BS, Hyde TM, Herman MM, Apud J, Egan MF, Kleinman JE, Weinberger DR (2004) Functional analysis of genetic variation in catechol-0-methyltransferase (COMT): effects on mRNA, protein, and enzyme activity in postmortem human brain. Am J Hum Genet 75:807821.

Chen J-K, Johnston KM, Petrides M, Ptito A (2008a) Neural substrates of symptoms of depression following concussion in male athletes with persisting postconcussion symptoms. Arch Gen Psychiatry 65:81-89.

Chen J-K, Johnston KM, Petrides M, Ptito A (2008b) Recovery from mild head injury in sports: evidence from serial functional magnetic resonance imaging studies in male athletes. Clin J Sport Med 18:241-247.

Clausen F, Hånell A, Israelsson C, Hedin J, Ebendal T, Mir AK, Gram H, Marklund N (2011) Neutralization of interleukin-1 beta reduces cerebral edema and tissue loss and improves late cognitive outcome following traumatic brain injury in mice. Eur J Neurosci 34:110-123.

Cohen RA, Grieve S, Hoth KF, Paul RH, Sweet L, Tate D, Gunstad J, Stroud L, McCaffery J, Hitsman B, Niaura R, Clark CR, MacFarlane A, Bryant R, Gordon E, Williams LM (2006) Early Life Stress and Morphometry of the Adult Anterior Cingulate Cortex and Caudate Nuclei. Biol Psychiatry 59:975-982.

Corbetta M, Akbudak E, Conturo TE, Snyder AZ, Ollinger JM, Drury HA, Linenweber MR, Petersen SE, Raichle ME, Van Essen DC, Shulman GL (1998) A common network of functional areas for attention and eye movements. Neuron 21:761-773.

Covassin T, Elbin RJ, Harris W, Parker T, Kontos A (2012) The role of age and sex in symptoms, neurocognitive performance, and postural stability in athletes after concussion. Am J Sports Med 40:1303-1312.

Dai J, Buijs R, Swaab D (2004) Glucocorticoid hormone (cortisol) affects axonal transport in human cortex neurons but shows resistance in Alzheimer's disease. Br J Pharmacol 143:606-610. 
De Graaf LE, Roelofs J, Huibers MJH (2009) Measuring Dysfunctional Attitudes in the General Population: The Dysfunctional Attitude Scale (form A) Revised. Cognit Ther Res 33:345-355.

Dettwiler A, Murugavel M, Putukian M, Cubon V, Furtado J, Osherson D (2014) Persistent differences in patterns of brain activation after sports-related concussion: a longitudinal functional magnetic resonance imaging study. J Neurotrauma 31:180188.

Disner SG, Beevers CG, Haigh EAP, Beck AT (2011) Neural mechanisms of the cognitive model of depression. Nat Rev Neurosci 12:467-477.

Dougan BK, Horswill MS, Geffen GM (2014) Athletes' age, sex, and years of education moderate the acute neuropsychological impact of sports-related concussion: a metaanalysis. J Int Neuropsychol Soc 20:64-80.

Duan J, Wainwright MS, Comeron JM, Saitou N, Sanders AR, Gelernter J, Gejman P V (2003) Synonymous mutations in the human dopamine receptor D2 (DRD2) affect mRNA stability and synthesis of the receptor. Hum Mol Genet 12:205-216.

Dumitriu D, Hao J, Hara Y, Kaufmann J, Janssen WGM, Lou W, Rapp PR, Morrison JH (2010) Selective changes in thin spine density and morphology in monkey prefrontal cortex correlate with aging-related cognitive impairment. J Neurosci 30:7507-7515.

Egan MF, Kojima M, Callicott JH, Goldberg TE, Kolachana BS, Bertolino A, Zaitsev E, Gold B, Goldman D, Dean M, Lu B, Weinberger DR (2003) The BDNF val66met polymorphism affects activity-dependent secretion of BDNF and human memory and hippocampal function. Cell 112:257-269.

Ellemberg D, Leclerc S, Couture S, Daigle C (2007) Prolonged neuropsychological impairments following a first concussion in female university soccer athletes. Clin J Sport Med 17:369-374.

Eugène F, Joormann J, Cooney RE, Atlas LY, Gotlib IH (2010) Neural correlates of inhibitory deficits in depression. Psychiatry Res 181:30-35.

Fan L, Young PR, Barone FC, Feuerstein GZ, Smith DH, McIntosh TK (1995) Experimental brain injury induces expression of interleukin- $1 \beta$ mRNA in the rat brain. Mol Brain Res 30:125-130.

Fava M, Rosenbaum JF, Kolsky AR, Alpert JE, Nierenberg AA, Spillmann M, Moore C, Renshaw P, Bottiglieri T, Moroz G, Magni G (1999) Open study of the catechol-0methyltransferase inhibitor tolcapone in major depressive disorder. J Clin Psychopharmacol 19:329-335. 
Ferrari AJ, Somerville AJ, Baxter AJ, Norman R, Patten SB, Vos T, Whiteford HA (2013) Global variation in the prevalence and incidence of major depressive disorder: a systematic review of the epidemiological literature. Psychol Med 43:471-481.

Funahashi S, Andreau JM (2013) Prefrontal cortex and neural mechanisms of executive function. J Physiol Paris 107:471-482.

Ganti L, Khalid H, Patel PS, Daneshvar Y, Bodhit AN, Peters KR (2014) Who gets postconcussion syndrome? An emergency department-based prospective analysis. Int J Emerg Med 7:31.

Gardner RC, Yaffe K (2015) Epidemiology of mild traumatic brain injury and neurodegenerative disease. Mol Cell Neurosci.

Gatt JM, Nemeroff CB, Dobson-Stone C, Paul RH, Bryant RA, Schofield PR, Gordon E, Kemp AH, Williams LM (2009) Interactions between BDNF Val66Met polymorphism and early life stress predict brain and arousal pathways to syndromal depression and anxiety. Mol Psychiatry 14:681-695.

Gerra G, Volpi R, Delsignore R, Maninetti L, Caccavari R, Vourna S, Maestri D, Chiodera P, Ugolotti G, Coiro V (1992) Sex-related responses of beta-endorphin, ACTH, GH and PRL to cold exposure in humans. Acta Endocrinol (Copenh) 126:24-28.

Ghosh A, Carnahan J, Greenberg ME (1994) Requirement for BDNF in activity-dependent survival of cortical neurons. Science 263:1618-1623.

Giza CC, Hovda DA (2001) The Neurometabolic Cascade of Concussion. J Athl Train 36:228235.

Goel N, Workman JL, Lee TT, Innala L, Viau V (2014) Sex differences in the HPA axis. Compr Physiol 4:1121-1155.

Goeleven E, De Raedt R, Baert S, Koster EHW (2006) Deficient inhibition of emotional information in depression. J Affect Disord 93:149-157.

Goldstein FC, Levin HS, Goldman WP, Clark AN, Altonen TK (2001) Cognitive and neurobehavioral functioning after mild versus moderate traumatic brain injury in older adults. J Int Neuropsychol Soc 7:373-383.

Grant DA, Berg E (1948) A behavioral analysis of degree of reinforcement and ease of shifting to new responses in a Weigl-type card-sorting problem. J Exp Psychol 38:404411.

Grimm S et al. (2008) Imbalance between Left and Right Dorsolateral Prefrontal Cortex in Major Depression Is Linked to Negative Emotional Judgment: An fMRI Study in Severe Major Depressive Disorder. Biol Psychiatry 63:369-376. 
Gunnar MR, Wewerka S, Frenn K, Long JD, Griggs C (2009) Developmental changes in hypothalamus-pituitary-adrenal activity over the transition to adolescence: normative changes and associations with puberty. Dev Psychopathol 21:69-85.

Guskiewicz KM, Marshall SW, Bailes J, McCrea M, Harding HP, Matthews A, Mihalik JR, Cantu RC (2007) Recurrent concussion and risk of depression in retired professional football players. Med Sci Sports Exerc 39:903-909.

Hankin BL, Oppenheimer C, Jenness J, Barrocas A, Shapero BG, Goldband J (2009) Developmental origins of cognitive vulnerabilities to depression: review of processes contributing to stability and change across time. J Clin Psychol 65:1327-1338.

Harrisberger F, Smieskova R, Schmidt A, Lenz C, Walter A, Wittfeld K, Grabe HJ, Lang UE, Fusar-Poli P, Borgwardt S (2015) BDNF Val66Met polymorphism and hippocampal volume in neuropsychiatric disorders: A systematic review and meta-analysis. Neurosci Biobehav Rev 55:107-118.

Heim C, Newport DJ, Heit S, Graham YP, Wilcox M, Bonsall R, Miller AH, Nemeroff CB (2000) Pituitary-adrenal and autonomic responses to stress in women after sexual and physical abuse in childhood. JAMA 284:592-597.

Hirvonen M, Laakso A, Någren K, Rinne JO, Pohjalainen T, Hietala J (2004) C957T polymorphism of the dopamine D2 receptor (DRD2) gene affects striatal DRD2 availability in vivo. Mol Psychiatry 9:1060-1061.

Hirvonen MM, Laakso A, Någren K, Rinne JO, Pohjalainen T, Hietala J (2009a) C957T polymorphism of dopamine D2 receptor gene affects striatal DRD2 in vivo availability by changing the receptor affinity. Synapse 63:907-912.

Hirvonen MM, Lumme V, Hirvonen J, Pesonen U, Någren K, Vahlberg T, Scheinin H, Hietala J (2009b) C957T polymorphism of the human dopamine D2 receptor gene predicts extrastriatal dopamine receptor availability in vivo. Prog Neuropsychopharmacol Biol Psychiatry 33:630-636.

Hofer M, Pagliusi SR, Hohn A, Leibrock J, Barde YA (1990) Regional distribution of brainderived neurotrophic factor mRNA in the adult mouse brain. EMBO J 9:2459-2464.

Hosang GM, Shiles C, Tansey KE, McGuffin P, Uher R (2014) Interaction between stress and the BDNF Val66Met polymorphism in depression: a systematic review and metaanalysis. BMC Med 12:7.

Jantzen KJ, Anderson B, Steinberg FL, Kelso JAS (2004) A prospective functional MR imaging study of mild traumatic brain injury in college football players. AJNR Am J Neuroradiol 25:738-745. 
Jezová D, Kvetnanský R, Vigas M (1994) Sex differences in endocrine response to hyperthermia in sauna. Acta Physiol Scand 150:293-298.

Joormann J, Yoon KL, Zetsche U (2007) Cognitive inhibition in depression. Appl Prev Psychol 12:128-139.

Kastner S, De Weerd P, Desimone R, Ungerleider LG (1998) Mechanisms of directed attention in the human extrastriate cortex as revealed by functional MRI. Science 282:108-111.

Kelly DL, Rowland LM, Patchan KM, Sullivan K, Earl A, Raley H, Liu F, Feldman S, McMahon RP (2016) Schizophrenia clinical symptom differences in women vs. men with and without a history of childhood physical abuse. Child Adolesc Psychiatry Ment Health 10:5.

Kendler KS, Karkowski LM, Prescott CA (1999) Causal relationship between stressful life events and the onset of major depression. Am J Psychiatry 156:837-841.

Kerr ZY, Evenson KR, Rosamond WD, Mihalik JP, Guskiewicz KM, Marshall SW (2014) Association between concussion and mental health in former collegiate athletes. Inj Epidemiol 1:28.

King N (2014) Permanent post concussion symptoms after mild head injury: a systematic review of age and gender factors. NeuroRehabilitation 34:741-748.

Kolb B, Mychasiuk R, Muhammad A, Li Y, Frost DO, Gibb R (2012) Experience and the developing prefrontal cortex. Proc Natl Acad Sci U S A 109 Suppl :17186-17193.

Lachman HM, Papolos DF, Saito T, Yu YM, Szumlanski CL, Weinshilboum RM (1996) Human catechol-0-methyltransferase pharmacogenetics: description of a functional polymorphism and its potential application to neuropsychiatric disorders. Pharmacogenetics 6:243-250.

Lamb YN, McKay NS, Thompson CS, Hamm JP, Waldie KE, Kirk IJ (2014) Brain-derived neurotrophic factor Val66Met polymorphism, human memory, and synaptic neuroplasticity. Wiley Interdiscip Rev Cogn Sci 6:97-108.

Legge RM, Sendi S, Cole JH, Cohen-Woods S, Costafreda SG, Simmons A, Farmer AE, Aitchison KJ, McGuffin P, Fu CHY (2015) Modulatory effects of brain-derived neurotrophic factor Val66Met polymorphism on prefrontal regions in major depressive disorder. Br J Psychiatry 206:379-384.

Levin HS, Brown SA, Song JX, McCauley SR, Boake C, Contant CF, Goodman H, Kotrla KJ (2001) Depression and posttraumatic stress disorder at three months after mild to moderate traumatic brain injury. J Clin Exp Neuropsychol 23:754-769. 
Logue SF, Gould TJ (2014) The neural and genetic basis of executive function: attention, cognitive flexibility, and response inhibition. Pharmacol Biochem Behav 123:45-54.

Lumme V, Aalto S, Ilonen T, Någren K, Hietala J (2007) Dopamine D2/D3 receptor binding in the anterior cingulate cortex and executive functioning. Psychiatry Res Neuroimaging 156:69-74.

Lupien SJ, McEwen BS, Gunnar MR, Heim C (2009) Effects of stress throughout the lifespan on the brain, behaviour and cognition. Nat Rev Neurosci 10:434-445.

Mandelli L, Petrelli C, Serretti A (2015) The role of specific early trauma in adult depression: A meta-analysis of published literature. Childhood trauma and adult depression. Eur Psychiatry 30:665-680.

Mandelli L, Serretti A, Marino E, Pirovano A, Calati R, Colombo C (2007) Interaction between serotonin transporter gene, catechol-0-methyltransferase gene and stressful life events in mood disorders. Int J Neuropsychopharmacol 10:437-447.

Matsuo K, Glahn DC, Peluso MAM, Hatch JP, Monkul ES, Najt P, Sanches M, Zamarripa F, Li J, Lancaster JL, Fox PT, Gao J-H, Soares JC (2007) Prefrontal hyperactivation during working memory task in untreated individuals with major depressive disorder. Mol Psychiatry 12:158-166.

McAllister TW, Flashman LA, Harker Rhodes C, Tyler AL, Moore JH, Saykin AJ, McDonald BC, Tosteson TD, Tsongalis GJ (2008) Single nucleotide polymorphisms in ANKK1 and the dopamine D2 receptor gene affect cognitive outcome shortly after traumatic brain injury: a replication and extension study. Brain Inj 22:705-714.

McAllister TW, Rhodes CH, Flashman LA, McDonald BC, Belloni D, Saykin AJ (2005) Effect of the dopamine $\mathrm{D} 2$ receptor $\mathrm{T}$ allele on response latency after mild traumatic brain injury. Am J Psychiatry 162:1749-1751.

McAllister TW, Tyler AL, Flashman LA, Rhodes CH, McDonald BC, Saykin AJ, Tosteson TD, Tsongalis GJ, Moore JH (2012) Polymorphisms in the brain-derived neurotrophic factor gene influence memory and processing speed one month after brain injury. J Neurotrauma 29:1111-1118.

McCauley SR, Boake C, Levin HS, Contant CF, Song JX (2001) Postconcussional disorder following mild to moderate traumatic brain injury: anxiety, depression, and social support as risk factors and comorbidities. J Clin Exp Neuropsychol 23:792-808.

McCauley SR, Wilde EA, Miller ER, Frisby ML, Garza HM, Varghese R, Levin HS, Robertson CS, McCarthy JJ (2013) Preinjury resilience and mood as predictors of early outcome following mild traumatic brain injury. J Neurotrauma 30:642-652. 
McCrory P et al. (2013) Consensus statement on concussion in sport: the 4th International Conference on Concussion in Sport held in Zurich, November 2012. Br J Sports Med 47:250-258.

McEwen BS, Morrison JH (2013) The brain on stress: vulnerability and plasticity of the prefrontal cortex over the life course. Neuron 79:16-29.

McGowan PO, Sasaki A, D’Alessio AC, Dymov S, Labonté B, Szyf M, Turecki G, Meaney MJ (2009) Epigenetic regulation of the glucocorticoid receptor in human brain associates with childhood abuse. Nat Neurosci 12:342-348.

Merritt VC, Arnett PA (2014) Premorbid predictors of postconcussion symptoms in collegiate athletes. J Clin Exp Neuropsychol 36:1098-1111.

Mitterschiffthaler MT, Williams SCR, Walsh ND, Cleare AJ, Donaldson C, Scott J, Fu CHY (2008) Neural basis of the emotional Stroop interference effect in major depression. Psychol Med 38:247-256.

Monakhov M, Golimbet V, Abramova L, Kaleda V, Karpov V (2008) Association study of three polymorphisms in the dopamine D2 receptor gene and schizophrenia in the Russian population. Schizophr Res 100:302-307.

Mooney G, Speed J (2001) The association between mild traumatic brain injury and psychiatric conditions. Brain Inj 15:865-877.

Moore RD, Hillman CH, Broglio SP (2013) The persistent influence of concussive injuries on cognitive control and neuroelectric function. J Athl Train 49:24-35.

Mueller ST (2011) PEBL: The Psychology Experiment Building Language.

Mueller ST, Piper BJ (2014) The Psychology Experiment Building Language (PEBL) and PEBL Test Battery. J Neurosci Methods 222:250-259.

Murer MG, Yan Q, Raisman-Vozari R (2001) Brain-derived neurotrophic factor in the control human brain, and in Alzheimer's disease and Parkinson's disease. Prog Neurobiol 63:71-124.

O'Connor TG, Ben-Shlomo Y, Heron J, Golding J, Adams D, Glover V (2005) Prenatal Anxiety Predicts Individual Differences in Cortisol in Pre-Adolescent Children. Biol Psychiatry 58:211-217.

Olsson KA, Lloyd OT, Lebrocque RM, McKinlay L, Anderson VA, Kenardy JA (2013) Predictors of child post-concussion symptoms at 6 and 18 months following mild traumatic brain injury. Brain Inj 27:145-157. 
Opmeer EM, Kortekaas R, Aleman A (2010) Depression and the role of genes involved in dopamine metabolism and signalling. Prog Neurobiol 92:112-133.

Patterson ZR, Holahan MR (2012) Understanding the neuroinflammatory response following concussion to develop treatment strategies. Front Cell Neurosci 6:58.

Pezawas L, Verchinski BA, Mattay VS, Callicott JH, Kolachana BS, Straub RE, Egan MF, Meyer-Lindenberg A, Weinberger DR (2004) The brain-derived neurotrophic factor val66met polymorphism and variation in human cortical morphology. J Neurosci 24:10099-10102.

Ponsford J, Cameron P, Fitzgerald M, Grant M, Mikocka-Walus A, Schönberger M (2012) Predictors of postconcussive symptoms 3 months after mild traumatic brain injury. Neuropsychology 26:304-313.

Ponsford J, Willmott C, Rothwell A, Cameron P, Kelly AM, Nelms R, Curran C, Ng K (2000) Factors influencing outcome following mild traumatic brain injury in adults. J Int Neuropsychol Soc 6:568-579.

Pontifex MB, Broglio SP, Drollette ES, Scudder MR, Johnson CR, O'Connor PM, Hillman CH (2012) The relation of mild traumatic brain injury to chronic lapses of attention. Res $Q$ Exerc Sport 83:553-559.

Preacher KJ, Curran PJ, Bauer DJ (2006) Computational Tools for Probing Interactions in Multiple Linear Regression, Multilevel Modeling, and Latent Curve Analysis. J Educ Behav Stat 31:437-448.

Pu S, Yamada T, Yokoyama K, Matsumura H, Kobayashi H, Sasaki N, Mitani H, Adachi A, Kaneko K, Nakagome K (2011) A multi-channel near-infrared spectroscopy study of prefrontal cortex activation during working memory task in major depressive disorder. Neurosci Res 70:91-97.

Richter P, Werner J, Heerlein A, Kraus A, Sauer H (1998) On the validity of the Beck Depression Inventory. A review. Psychopathology 31:160-168.

Rutherford W, McDonald JR, Merrett JD (1977) Sequelae of concussion caused by minor head injuries. Lancet 309:1-4.

Shafritz KM, Collins SH, Blumberg HP (2006) The interaction of emotional and cognitive neural systems in emotionally guided response inhibition. Neuroimage 31:468-475.

Shonkoff JP, Garner AS (2012) The lifelong effects of early childhood adversity and toxic stress. Pediatrics 129:e232-e246.

Signoretti S, Lazzarino G, Tavazzi B, Vagnozzi R (2011) The pathophysiology of concussion. PM R 3:S359-S368. 
Slobounov SM, Zhang K, Pennell D, Ray W, Johnson B, Sebastianelli W (2010) Functional abnormalities in normally appearing athletes following mild traumatic brain injury: a functional MRI study. Exp brain Res 202:341-354.

Smolka MN, Schumann G, Wrase J, Grüsser SM, Flor H, Mann K, Braus DF, Goldman D, Büchel C, Heinz A (2005) Catechol-0-methyltransferase val158met genotype affects processing of emotional stimuli in the amygdala and prefrontal cortex. J Neurosci 25:836-842.

Solomon GS, Kuhn AW, Zuckerman SL (2015) Depression as a Modifying Factor in SportsRelated Concussion: A Critical Review of the Literature. Phys Sportsmed.

Stein TD, Alvarez VE, McKee AC (2015) Concussion in Chronic Traumatic Encephalopathy. Curr Pain Headache Rep 19:522.

Sterr A, Herron KA, Hayward C, Montaldi D (2006) Are mild head injuries as mild as we think? Neurobehavioral concomitants of chronic post-concussion syndrome. BMC Neurol 6:7.

Stuss DT (2011) Functions of the Frontal Lobes: Relation to Executive Functions. J Int Neuropsychol Soc 17:759-765.

Stuss DT, Benson DF (1984) Neuropsychological studies of the frontal lobes. Psychol Bull 95:3-28.

Teasdale JD (1988) Cognitive Vulnerability to Persistent Depression. Cogn Emot 2:247274.

Thompson J, Thomas N, Singleton A, Piggott M, Lloyd S, Perry EK, Morris CM, Perry RH, Ferrier IN, Court JA (1997) D2 dopamine receptor gene (DRD2) Taq1 A polymorphism: reduced dopamine D2 receptor binding in the human striatum associated with the A1 allele. Pharmacogenetics 7:479-484.

Thompson JL, Kelly M, Kimhy D, Harkavy-Friedman JM, Khan S, Messinger JW, Schobel S, Goetz R, Malaspina D, Corcoran C (2009) Childhood trauma and prodromal symptoms among individuals at clinical high risk for psychosis. Schizophr Res 108:176-181.

Tunbridge EM, Bannerman DM, Sharp T, Harrison PJ (2004) Catechol-o-methyltransferase inhibition improves set-shifting performance and elevates stimulated dopamine release in the rat prefrontal cortex. J Neurosci 24:5331-5335.

Van Veldhoven LM, Sander AM, Struchen MA, Sherer M, Clark AN, Hudnall GE, Hannay HJ (2011) Predictive ability of preinjury stressful life events and post-traumatic stress symptoms for outcomes following mild traumatic brain injury: analysis in a prospective emergency room sample. J Neurol Neurosurg Psychiatry 82:782-787. 
Vargas G, Rabinowitz A, Meyer J, Arnett PA (2015) Predictors and prevalence of postconcussion depression symptoms in collegiate athletes. J Athl Train 50:250-255.

Verhagen M, van der Meij A, van Deurzen PAM, Janzing JGE, Arias-Vásquez A, Buitelaar JK, Franke B (2010) Meta-analysis of the BDNF Val66Met polymorphism in major depressive disorder: effects of gender and ethnicity. Mol Psychiatry 15:260-271.

Wang X-L, Du M-Y, Chen T-L, Chen Z-Q, Huang X-Q, Luo Y, Zhao Y-J, Kumar P, Gong Q-Y (2015) Neural correlates during working memory processing in major depressive disorder. Prog Neuropsychopharmacol Biol Psychiatry 56:101-108.

Wetmore C, Ernfors P, Persson H, Olson L (1990) Localization of brain-derived neurotrophic factor mRNA to neurons in the brain by in situ hybridization. Exp Neurol 109:141-152.

White TP et al. (2014) Sex differences in COMT polymorphism effects on prefrontal inhibitory control in adolescence. Neuropsychopharmacology 39:2560-2569.

Whitmer AJ, Gotlib IH (2012) Depressive rumination and the C957T polymorphism of the DRD2 gene. Cogn Affect Behav Neurosci 12:741-747.

Willmott C, Withiel T, Ponsford J, Burke R (2014) COMT Val158Met and cognitive and functional outcomes after traumatic brain injury. J Neurotrauma 31:1507-1514.

Winkler EA et al. (2015) COMT Val (158) Met polymorphism is associated with nonverbal cognition following mild traumatic brain injury. Neurogenetics.

Winter CD, Iannotti F, Pringle AK, Trikkas C, Clough GF, Church MK (2002) A microdialysis method for the recovery of IL-1 $\beta$, IL- 6 and nerve growth factor from human brain in vivo. J Neurosci Methods 119:45-50.

Withall A, Harris LM, Cumming SR (2009) The relationship between cognitive function and clinical and functional outcomes in major depressive disorder. Psychol Med 39:393402.

Xie T, Ho SL, Ramsden D (1999) Characterization and implications of estrogenic downregulation of human catechol-0-methyltransferase gene transcription. Mol Pharmacol 56:31-38.

Xie Z, Maddox WT, McGeary JE, Chandrasekaran B (2015) The C957T polymorphism in the dopamine receptor $\mathrm{D}_{2}$ gene modulates domain-general category learning. J Neurophysiol 113:3281-3290.

Xu H, Kellendonk CB, Simpson EH, Keilp JG, Bruder GE, Polan HJ, Kandel ER, Gilliam TC (2007) DRD2 C957T polymorphism interacts with the COMT Val158Met polymorphism in human working memory ability. Schizophr Res 90:104-107. 
You S, Merritt RD, Conner KR (2009) Do gender differences in the role of dysfunctional attitudes in depressive symptoms depend on depression history? Pers Individ Dif 46:218-223.

Zemek R et al. (2016) Clinical Risk Score for Persistent Postconcussion Symptoms Among Children With Acute Concussion in the ED. JAMA 315:1014-1025.

Zhao H, Guo W, Niu W, Zhong A, Zhou X (2015) Brain area-related neurological soft signs in depressive patients with different types of childhood maltreatment. Asia-Pacific Psychiatry 7:286-291. 


\section{Appendices}

Appendix A: Recruitment Notice

Study Title: Genetics of Cognition

Abstract: The purpose of the present study is to examine the extent to which several neurotransmitter gene variants interact with early life experiences to predict different aspects of decision-making, such as planning, problem-solving, and risk-taking. We are also interested in determining whether these aspects of decision-making are related to the way individuals cope with stressful experiences and mental health. You will be asked to provide a saliva sample for DNA analysis, complete 4 decision-making tasks, and a series of questionnaires about your background, how you cope with stressful events, your early life experiences, and mental health.

* Please note that some of these questionnaires are of a sensitive nature as they involve questions about early life trauma, such as physical, sexual, and emotional abuse, negative thinking and symptoms of depression. If you feel answering these types of questions may provoke distress or discomfort, we strongly suggest you do not sign up for this study*.

**Please do not, eat, drink coffee or tea, or smoke 30 minutes prior to the experiment**

Duration: Approximately 2 hours

Credit: $\quad 2 \%$

Eligibility: Undergraduate student at Carleton University, who can receive experimental credits for participation.

This study has received clearance by the Carleton University Psychology Research Ethics Board

(Reference \#13-126). 


\title{
Appendix B: Informed Consent
}

The purpose of an informed consent is to ensure that you understand the purpose of the study and the nature of your involvement. The informed consent has to provide sufficient information such that you have the opportunity to determine whether you wish to participate in the study.

\section{Study title: Genetics of Cognition}

Ethics \# 13-126

\section{Contacts}

The following people are involved in this research project and may be contacted at any time if you have further questions about this project, what it means, or concerns about how it was conducted:

Robert Gabrys

Department of Neuroscience

Phone: 613 5200-2600 ext 2692

Email: robertgabrys@cmail.carleton.ca

\author{
Dr. Hymie Anisman \\ Department of Neuroscience \\ Phone: 520-2699 \\ Email: hymie anisman@carleton.ca
}

Ethical concerns: Should you have any ethical concerns about this research, please contact Dr. Shelley Brown, at: shelley_brown@carleton.ca (613-520-2600 ext. 1505).

Any other concerns: For any other concerns, please contact Dr. John Stead (Department of Neuroscience Chair, 613-520-2600, ext. 8774, john stead@carleton.ca) or Dr. Anne Bowker (Psychology Department Chair, 613-520-2600, ext. 8218, anne.bowker@carleton.ca).

\section{Purpose}

The purpose of the present study is to examine the extent to which several neurotransmitter gene variants (e.g., serotonin and dopamine) interact with early life experiences to predict different aspects of decision-making, such as planning, problem-solving, and risk-taking. We are also interested in determining whether these aspects of decision-making are related to the way individuals cope with stressful experiences and mental health. Finally, we are also interested in determining whether the impact of brain injury (e.g., concussion) on decision-making in dependent on certain genetic variants.

Task Requirements:

You will, initially, be asked to provide a saliva sample for DNA analysis. This simply involves spitting into a tube for about 2 to 3 minutes. Next, you will complete 4 decision-making tasks which, together, take approximately 30 to 45 minutes. For the final part of the study, you will complete a series of questionnaires about your background, how you cope with stressful events, your early life experiences, and mental health. 
Potential risks or causes of discomfort for participants

Please note that some of these questionnaires are of a sensitive nature as they involve questions about early life trauma, such as physical, sexual, and emotional abuse, negative thinking and symptoms of depression. For some individuals, answering these types of questions can bring back some painful memories and cause some distress or discomfort. You are not obligated to answer any questions you do not feel comfortable answering, and you may skip any questions without penalty (i.e., you will still be granted your research participation course credit).

Anonymity and confidentiality

All information and samples collected from you for this study will be identified with a code number, as opposed to any personal identifiers such as your name or address. We will maintain a separate record that matches your personal identification details with this code number. This is necessary in order for us to re-contact you in the future (with your express permission to do so), and so that we can respect your right to withdraw from the study at a later date (to be described below). However, this record that allows your identity to be linked to your information will be kept in a separate and secured location, and will only be accessible to the primary researchers, in order to maintain anonymity and confidentiality of your information. All personal identifying information will be destroyed within 3 years of collection.

Right to Withdraw: Your participation in this study is entirely voluntary. At any point during the experiment you have the right tasks or questionnaires, or to withdraw from the study entirely. If you choose to withdraw you will still be provided access to the debriefing, and will still be granted your research participation course credit.

\section{Benefits}

Your participation in this study will help researchers to further understand the genetic and psychosocial factors involved in decision-making. More important, with these findings we hope to further improve the diagnosis and treatment for depression

Genetic testing: Common questions and concerns

What is DNA?

DNA is a large molecule that contains information necessary for our bodies to build all the components needed for our development, growth and survival. This information is commonly referred to as the genetic code or the DNA sequence. Some rare diseases can be attributed entirely to simple errors in our DNA sequence. However, the majority of common diseases (including depression) are caused by a combination of many different genetic factors, together with environmental factors (how we grew up, life events, etc).

What will my DNA be used for?

If you compare any two people, their DNA will be about $99 \%$ identical. We are interested in the $1 \%$ of DNA that is different between people. Our current plan is to investigate these differences, focusing on just a small proportion of your genes (we are targeting less than 100 of the $\sim 30,000$ genes that humans have) which we anticipate may be involved in risk of either anxiety or depression.

We are also planning future follow-up studies on your DNA, which will extend the analysis to substantially more genes - potentially all genes. These future studies will be limited to analyses of the DNA molecule and the genetic code, and will not involve any other use or 
manipulation of your DNA sample. However, in no case will your samples be kept for more than 3 years, at which time the samples and the sample container will be incinerated. Thus, the data derived from the sample will be kept (stripped of any information that could identify you), but the sample or remnants of the sample, including DNA, will be destroyed (incinerated). At the end of this form, you have the option to opt-out of any such future uses of your DNA sample.

How long will my DNA be stored, and potentially used in research?

By providing a DNA sample and signing this form, you are indicating that you allow us to preserve and analyze your DNA sample for an extended period of time (3 years or less). During this period, use of the sample is guaranteed to be limited to studies that read the DNA molecule. As indicated above, your saliva and any DNA samples will be destroyed, by incineration, no later than 3 years after saliva was collected.

Will I be told the results of my own genetic analysis?

No. Your DNA sample and genetic information will be identified by a code number, and not your name. This preserves confidentiality of this information. Returning your personal genetic information to you would require that confidentiality to be compromised, and will therefore be avoided. Furthermore, as described above, genetic data collected in this study will not allow accurate prediction of whether or not you will develop any disease. It would therefore be irresponsible of the researchers to inform participants that they had a slight increase in susceptibility to disease (as this could cause undue stress to both participants and their families), or that they had increased protection against disease.

What if something unexpected and potentially dangerous is discovered in my DNA None of the DNA sites that we plan to analyze is currently known to be predictive of disease with any real accuracy. However, future advances in genetic research could allow disease predictions to be possible based on information from these, or other genetic sites. In exceptional circumstances, if genetic research reveals information about a serious or lifethreatening condition that can be prevented or treated through intervention, then we have an obligation to inform you of this information, and potentially also inform your biological relatives who may share similar risk of disease. This would therefore represent a potential breach of confidentiality. In this instance, only information directly relating to disease diagnosis, and participant identity, would be shared. We wish to make clear, however, that it is not our intent to systematically go through the samples after our initial analyses, and so even if it was subsequently discovered that certain genes might carry relevant information for you, it is unlikely that we would actually locate any vulnerabilities you might have.

Can my DNA ever be used to identify me?

This is a complicated question to answer. Unless you have an identical twin (whose DNA will be identical to yours), your DNA is absolutely unique to you. It is this unique nature of genetic material that allows individuals to be identified based entirely on their DNA, through techniques such as DNA fingerprinting. It is therefore theoretically possible that in the future, your identity could be determined from simply analyzing your DNA sample, but it is extremely unlikely. In order to identify you based purely on your DNA sample, it would be necessary to compare your DNA sample that you provide today, with another DNA sample from you in a DNA database, which is linked to your identity. DNA databases do exist in countries including Canada, Australia, USA and UK, but are limited to samples from criminal offenders. Access to these databases is strictly limited to law enforcement 
agencies and thus cannot be accessed by researchers. Access to DNA samples taken for this study will similarly be limited to the researchers, and will not be provided to any law enforcement agency unless we become legally obliged to do so (to our knowledge, this has never happened to any research group). Furthermore, these government DNA databases typically contain information about only 13 regions of human DNA, none of which are to be analyzed in the present study.

If you have any additional questions or concerns, please ask the researcher today, or contact any of the principal investigators at a later date.

Right to withdraw from this study

Participation in this study is entirely voluntary. At any point during the study you have the right to skip certain questions or to withdraw with no penalty whatsoever. Furthermore, if at a later date you wish to withdraw from the study, you can contact the principal investigators and we will destroy all of your records (questionnaire answers, responses from the interview, DNA sample) from this study. The only exception is where data have already been published. In this instance, unpublished data plus your DNA sample will be destroyed.

Declaration of consent

While we would ideally obtain consent to use your DNA for any future research studies that are aimed at analyzing DNA sequence (Option 1 below), if this is not preferable for you, please indicate below how you would like your sample to be treated in the future. There are no obligations or penalties for you associated with your selection.

Option 1: I grant the researcher permission to use my DNA/saliva sample for this and any future research studies that involve analyses of the DNA molecule.

Option 2: I grant the researcher permission to use my DNA/saliva sample for this ?. study but must re-contact me to seek consent to use my DNA/saliva sample in future research studies.

Option 3: I grant use of my DNA/saliva sample, but this use will be strictly limited

(2) to the analysis of $<100$ genes, as described in the current experiment. This can only be done within a 3 year period of my saliva being collected.

Signatures

I have read the above form and understand the conditions of my participation. My participation in this study is voluntary, and I understand that if at any time I wish to leave the experiment, I may do so without having to give an explanation and with no penalty whatsoever. Furthermore, I am also aware that the data gathered in this study are confidential and anonymous with respect to my personal identity. My signature indicates that I agree to participate in this study.

Participant's Full Name: Participant's Signature:

Researcher's Name: Researcher's Signature:

Date 


\title{
Appendix C: Written Debriefing
}

What are we trying to learn in this research?

In recent years, there has been growing interest in determining the extent to which our genetic background influences our decision-making capabilities. Decision-making is a complex process comprised several different cognitive sub-processes, such as attention, working memory, the ability to shift between different thoughts or ideas, and to ignore the ones that are irrelevant or inappropriate to a certain goal. From this perspective, it might not be surprising that many different genes are involved, including those responsible for the regulation of various neurotransmitters, such as serotonin, dopamine, and norepinephrine. Another important factor that may be influence decision-making is our previous life experiences, such as early life adversity or history of head injuries (e.g., concussions), which it believed to interact with our genes.

Given these observations, we are trying to learn which neurotransmitter genes are responsible for which aspect of decision-making, and how different types of stressful life events (i.e., childhood adversity and history of concussions) may also contribute in this regard. As decision-making is also important to how people cope with stressful situations, we are also interested in determine whether the interaction between certain genes and stressful life events are also associated with individual differences in coping style. Finally, we would like to figure out how this complex interaction between genes, stressful life events, and decision-making are related to vulnerability to depression.

Depression is a complex illness involving many different biological and psychological factors. As such, the specific symptom profile an individual might present with may be dependent on their genetic background as well as their early life experiences. With the findings obtained from this study, we hope to further understand the specific combination of factors which might increase vulnerability or resilience to depression. These findings can also lead to improved and more personalized treatment of major depression.

\section{Thank you for being part of our study!}

What if I have questions later?

Please contact:

\author{
Robert Gabrys \\ Department of Neuroscience \\ Phone: 613 5200-2600 ext 2692 \\ Email: robert gabrys@carleton.ca \\ Dr. Hymie Anisman \\ Department of Neuroscience \\ Phone: 520-2699 \\ Email: hymie anisman@carleton.ca
}

Ethical concerns: Should you have any ethical concerns about this research, please contact Dr. Shelley Brown, at: shelley_brown@carleton.ca (613-520-2600 ext. 1505).

Any other concerns: For any other concerns, please contact Dr. John Stead (Department of 
Neuroscience Chair, 613-520-2600, ext. 8774, john stead@carleton.ca) or Dr. Anne Bowker (Psychology Department Chair, 613-520-2600, ext. 8218, anne.bowker@carleton.ca).

Is there anything that I can do if I found this experiment to be emotionally draining?

Yes. If you have experienced any distress while completing this study, please consult the resources below:

\section{Carleton University Counselling Services}

Confidential personal counselling services are available for current Carleton University students. Our primary responsibility is to alleviate distress and promote healthy functioning by providing short-term counselling services. Students can self-refer to counselling. Some examples of the issues students may discuss with a counsellor include: coping with stress/homesickness, increasing sadness, handling a crisis, improving communication, learning to be assertive, increasing self-esteem, gender identity, understanding one's sexuality and dealing with alcohol and drug concerns.

To make an appointment for counselling:

For students living off campus: Main Clinic Rm. 2600 CTTC Bldg. to book in person or Call 613-520-6674

For students living in residence: Counselling is available Sept. to April Rm. 223D Res Commons Bldg. Call 613-520-2600 ext. 8061 for intake.

For International and Exchange students: Call 613-520-6674 and ask to book with the International Student Counsellor.

Drop-in 30 minute counselling sessions are available for all international students on Mondays at the ISSO starting at 1:30 p.m. This is an opportunity for you to speak with the International Student Counsellor about any concerns or challenges that you might be having.

When: Drop-in sessions will be held on Mondays from 1:30 to 3:00 p.m.

Where: Sessions will be held at the ISSO office, 128 University Centre.

What Do I Need to Do?: A same-day sign-up sheet will be at the reception desk of the ISSO starting at 8:30 a.m. on Monday mornings. You may also show up during the drop-in times to see if there is time available to meet with the Counsellor. You will be asked to fill out a 2 page intake form. Please arrive 10 minutes early to fill out the form.

Ottawa Distress Centre: (613) 238 1089, Web Site: www.dcottawa.on.ca. Mental Health Crisis Line: within Ottawa (613) 722-6914, outside Ottawa 1-866-9960991, Web Site: http://www.crisisline.ca/ 
Appendix D: Background Information

\section{Background Information}

Sex: ? Female ? Male

Age:

What is your citizenship status?

?]Canadian citizen

? Landed immigrant Since what year? Country of origin

? Student visa Since what year? Country of origin

?Temporary visa Since what year? Country of origin

?Refugee Since what year? Country of origin

What is your first language?

If your first language is not English, how long have you been fluent in reading, writing and comprehension of the English language?

What is your ethnic/racial background?

]Asian (e.g., Chinese, Japanese, Korean)

[?] South Asian (e.g., East Indian, Pakistani, Punjabi, Sri Lankan)

[South East Asian (e.g., Cambodian, Indonesian, Laotian)

]Arab/West Asian (e.g., Armenian, Egyptian, Iranian, Lebanese, Moroccan)

?Black (e.g., African, Haitian, Jamaican, Somali)

?Latin American/Hispanic

]Aboriginal

?White/Euro-Caucasian 
?0ther (please specify):

\section{Current Health, Medication and Treatments}

The following questions are important for our analysis of genes and computer tasks.

1. What time did you wake up today?

2. Have you had or do you currently have any health related illnesses or physical condition (e.g., diabetes, heart disease, autoimmune disease)?

?]No, I don't

??Yes, I did but I no longer do

?Yes, I do

If YES, please specify illness/condition you had/have

3. Have you ever been or are currently diagnosed with a psychological disorder/condition (e.g., depression or anxiety)?

?No, I am not

?Yes, I was but no longer

?Yes, I am

If YES, please specify disorder/condition

4. Have you ever been or are currently diagnosed with a neurological disorder/condition (e.g., epilepsy)?

? No, I am not

?Yes, I was but no longer

?Yes, I am

If YES, please specify disorder/condition 
5. Are you on any of the following medications (please check all that apply)?

? Anti-inflammatories (please specify)

?Anti-depressants (please specify)

? Anti-anxieties (please specify)

? Allergy medication (please specify)

?] Other prescription drugs (please specify)

Given the sensitivity of the computer tasks and gene assays to stimulants, please answer the following questions as truthful as possible

1. Did you have a cigarette in the past 30 minutes?

? YES ? NO

1.Did you have a coffee, tea or caffeinated beverage in the past 30 minutes?

? YES ? NO

2.Did you exercise in the past 30 minutes?

? YES ? NO

3.Did you chew gum in the past 30 minutes?

? YES ? NO

4.Did you eat in the past 30 minutes?

? YES ? NO

5.Did you have alcohol in the past 30 minutes?

? Y YES ? NO 
Appendix E: Computer-Based Tasks

Wisconsin Card Sorting Task

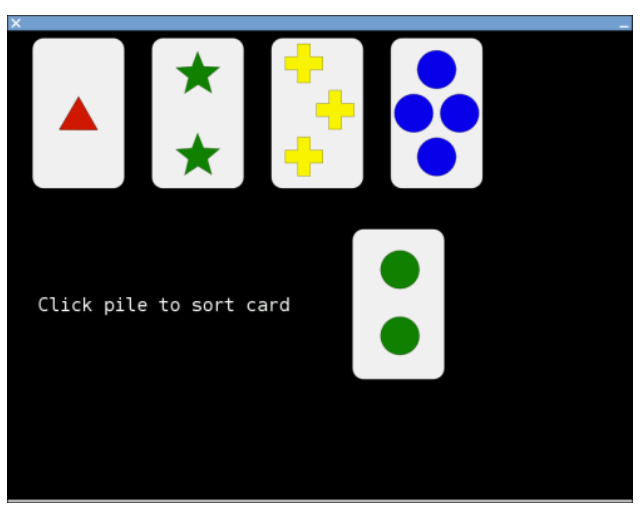


Appendix F: Dysfunctional Attitudes Scale- Short Form

\section{DAS-SF}

The sentences below describe people's attitudes. Circle the number which best describes how much each sentence describes your attitude. Your answer should describe the way you think most of the time.

\begin{tabular}{|c|c|c|}
\hline $\begin{array}{c}\text { Totally } \\
\text { Agree }\end{array}$ & Agre & Disagree \\
\hline
\end{tabular}

1. If I don't set the highest standards for

1

2

3

4 myself, I am likely to end up a secondrate person.

2. My value as a person depends greatly

1

2

3

4 on what others think of me.

3. People will probably think less of me if 1

2

3

4 I make a mistake.

4. I am nothing if a person I love doesn't

1

2

3

4

love me.

5. If other people know what you are 1

2

3

4 really like, they will think less of you.

6. If I fail at my work, then I am a failure 1

2 3 4 as a person.

7. My happiness depends more on other 1

2

3

4 people than it does me.

8. I cannot be happy unless most people I 1

2 know admire me.

9. It is best to give up your own interests 1 2 in order to please other people. 
Appendix G: Mild Traumatic Brain Injury

\section{Mild Traumatic Brain Injury}

Sometimes, while playing sports or as a result of an accident (e.g., car accident), people may experience a head injury and display various symptoms related to mild brain trauma (or concussion).

As a result of an accident, have you ever experienced a head injury (i.e., concussion)?

$\square$ Yes $\quad \square$ No

If yes, please answer the following questions (if no, move on to the next questionnaire).

1. Did you experience any loss of consciousness?

Yes $\square$ No

If yes, for how long (this can be seconds to minutes)?

2. Did you experience any loss of memory for events immediately before or after the accident?

Yes $\square$ No

If yes, for how long (this can be seconds, minutes, hours or days)?

3. Did you experience any alteration of mental state at the time of the accident (e.g., feeling dazed, disoriented, or confused)?

Yes $\square$ No

If yes, for how long (this can be seconds, minutes, hours or days)?

3. Did you receive medical attention?

$\square$ Yes $\square$ No

4. Did you visit the hospital/emergency room?

$\square$ Yes $\square$ No 
5. Was this an open (did you cut your head) or closed head injury?

$\square$ Yes $\square$ No

6. Did you fracture your skull?

$\square$ Yes $\square$ No

7. How many times did you experience one or more of these symptoms as a result of a head injury?

$\square$ Once $\quad \square$ Twice $\quad \square 3$ times $\quad \square 4$ times $\quad \square 5$ times $\quad \square$ More than 5 times 


\section{Appendix H: Early Life Trauma-Short Report}

\section{Early Life Trauma Inventory}

Most people have experienced a traumatic event at some point in their life. For this survey, we are interested in the types of traumatic events that you may have experienced, and how old you were when you experienced it. For each question, please indicate how many times you have experienced the event (if at all), and at what age range, by circling the appropriate number.

Part 1. General Traumas

1. Were you ever exposed to a life-threatening natural disaster?

\begin{tabular}{|c|c|c|c|c|c|c|}
\hline Age 0 to 5 & $\begin{array}{c}0 \\
\text { Never }\end{array}$ & $\begin{array}{c}1 \\
\text { Once }\end{array}$ & $\begin{array}{c}2 \\
2-3 \text { times }\end{array}$ & $\begin{array}{c}3 \\
4-5 \text { times }\end{array}$ & $\begin{array}{c}4 \\
6-10 \\
\text { times }\end{array}$ & $\begin{array}{c}5 \\
\text { More than } 10 \text { times }\end{array}$ \\
\hline Age 6 to 12 & $\begin{array}{c}0 \\
\text { Never }\end{array}$ & $\begin{array}{c}1 \\
\text { Once }\end{array}$ & $\begin{array}{c}2 \\
2-3 \text { times }\end{array}$ & $\begin{array}{c}3 \\
4-5 \text { times }\end{array}$ & $\begin{array}{c}4 \\
6-10 \\
\text { times } \\
\end{array}$ & $\begin{array}{c}5 \\
\text { More than } 10 \text { times }\end{array}$ \\
\hline Age 13 to 18 & $\begin{array}{c}0 \\
\text { Never }\end{array}$ & $\begin{array}{c}1 \\
\text { Once }\end{array}$ & $\begin{array}{c}2 \\
2-3 \text { times }\end{array}$ & $\begin{array}{c}3 \\
4-5 \text { times }\end{array}$ & $\begin{array}{c}4 \\
6-10 \\
\text { times }\end{array}$ & $\begin{array}{c}5 \\
\text { More than } 10 \text { times }\end{array}$ \\
\hline Age $18+$ & $\begin{array}{c}0 \\
\text { Never }\end{array}$ & $\begin{array}{c}1 \\
\text { Once }\end{array}$ & $\begin{array}{c}2 \\
2-3 \text { times }\end{array}$ & $\begin{array}{c}3 \\
4-5 \text { times }\end{array}$ & $\begin{array}{c}4 \\
6-10 \\
\text { times }\end{array}$ & $\begin{array}{c}5 \\
\text { More than } 10 \text { times }\end{array}$ \\
\hline \multicolumn{7}{|c|}{ 2. Were you involved in a serious accident? } \\
\hline Age 0 to 5 & $\begin{array}{c}0 \\
\text { Never }\end{array}$ & $\begin{array}{c}1 \\
\text { Once }\end{array}$ & $\begin{array}{c}2 \\
2-3 \text { times }\end{array}$ & $\begin{array}{c}3 \\
4-5 \text { times }\end{array}$ & $\begin{array}{c}4 \\
6-10 \\
\text { times } \\
\end{array}$ & $\begin{array}{c}5 \\
\text { More than } 10 \text { times }\end{array}$ \\
\hline Age 6 to 12 & $\begin{array}{c}0 \\
\text { Never }\end{array}$ & $\begin{array}{c}1 \\
\text { Once }\end{array}$ & $\begin{array}{c}2 \\
2-3 \text { times }\end{array}$ & $\begin{array}{c}3 \\
4-5 \text { times }\end{array}$ & $\begin{array}{c}4 \\
6-10 \\
\text { times }\end{array}$ & $\begin{array}{c}5 \\
\text { More than } 10 \text { times }\end{array}$ \\
\hline Age 13 to 18 & $\begin{array}{c}0 \\
\text { Never }\end{array}$ & $\begin{array}{c}1 \\
\text { Once }\end{array}$ & $\begin{array}{c}2 \\
2-3 \text { times }\end{array}$ & $\begin{array}{c}3 \\
4-5 \text { times }\end{array}$ & $\begin{array}{c}4 \\
6-10 \\
\text { times }\end{array}$ & $\begin{array}{c}5 \\
\text { More than } 10 \text { times }\end{array}$ \\
\hline Age $18+$ & $\begin{array}{c}0 \\
\text { Never }\end{array}$ & $\begin{array}{c}1 \\
\text { Once }\end{array}$ & $\begin{array}{c}2 \\
2-3 \text { times }\end{array}$ & $\begin{array}{c}3 \\
4-5 \text { times }\end{array}$ & $\begin{array}{c}4 \\
6-10 \\
\text { times } \\
\end{array}$ & $\begin{array}{c}5 \\
\text { More than } 10 \text { times }\end{array}$ \\
\hline \multicolumn{7}{|c|}{ 3. Did you ever suffer a serious personal injury or illness? } \\
\hline Age 0 to 5 & $\begin{array}{c}0 \\
\text { Never }\end{array}$ & $\begin{array}{c}1 \\
\text { Once }\end{array}$ & $\begin{array}{c}2 \\
2-3 \text { times }\end{array}$ & $\begin{array}{c}3 \\
4-5 \text { times }\end{array}$ & $\begin{array}{c}4 \\
6-10 \\
\text { times }\end{array}$ & $\begin{array}{c}5 \\
\text { More than } 10 \text { times }\end{array}$ \\
\hline Age 6 to 12 & $\begin{array}{c}0 \\
\text { Never }\end{array}$ & $\begin{array}{c}1 \\
\text { Once }\end{array}$ & $\begin{array}{c}2 \\
2-3 \text { times }\end{array}$ & $\begin{array}{c}3 \\
4-5 \text { times }\end{array}$ & $\begin{array}{c}4 \\
6-10 \\
\text { times }\end{array}$ & $\begin{array}{c}5 \\
\text { More than } 10 \text { times }\end{array}$ \\
\hline Age 13 to 18 & $\begin{array}{c}0 \\
\text { Never }\end{array}$ & $\begin{array}{c}1 \\
\text { Once }\end{array}$ & $\begin{array}{c}2 \\
2-3 \text { times }\end{array}$ & $\begin{array}{c}3 \\
4-5 \text { times }\end{array}$ & $\begin{array}{c}4 \\
6-10 \\
\text { times } \\
\end{array}$ & $\begin{array}{c}5 \\
\text { More than } 10 \text { times }\end{array}$ \\
\hline Age $18+$ & $\begin{array}{c}0 \\
\text { Never }\end{array}$ & $\begin{array}{c}1 \\
\text { Once }\end{array}$ & $\begin{array}{c}2 \\
2-3 \text { times }\end{array}$ & $\begin{array}{c}3 \\
4-5 \text { times }\end{array}$ & $\begin{array}{c} \\
6-10 \\
\text { times }\end{array}$ & $\begin{array}{c}5 \\
\text { More than } 10 \text { times }\end{array}$ \\
\hline \multicolumn{7}{|c|}{ 4. Did you ever experience the death or serious illness of a parent or a primary caretaker? } \\
\hline Age 0 to 5 & $\begin{array}{c}0 \\
\text { Never }\end{array}$ & $\begin{array}{c}1 \\
\text { Once }\end{array}$ & $\begin{array}{c}2 \\
2-3 \text { times }\end{array}$ & $\begin{array}{c}3 \\
4-5 \text { times }\end{array}$ & $\begin{array}{c}4 \\
6-10\end{array}$ & $\begin{array}{c}5 \\
\text { More than } 10 \text { times }\end{array}$ \\
\hline
\end{tabular}




\begin{tabular}{|c|c|c|c|c|c|c|}
\hline & & & & & times & \\
\hline Age 6 to 12 & $\begin{array}{c}0 \\
\text { Never }\end{array}$ & $\begin{array}{c}1 \\
\text { Once }\end{array}$ & $\begin{array}{c}2 \\
2-3 \text { times }\end{array}$ & $\begin{array}{c}3 \\
4-5 \text { times }\end{array}$ & $\begin{array}{c}4 \\
6-10 \\
\text { times }\end{array}$ & $\begin{array}{c}5 \\
\text { More than } 10 \text { times }\end{array}$ \\
\hline Age 13 to 18 & $\begin{array}{c}0 \\
\text { Never }\end{array}$ & $\begin{array}{c}1 \\
\text { Once }\end{array}$ & $\begin{array}{c}2 \\
2-3 \text { times }\end{array}$ & $\begin{array}{c}3 \\
4-5 \text { times }\end{array}$ & $\begin{array}{c}4 \\
6-10 \\
\text { times }\end{array}$ & $\begin{array}{c}5 \\
\text { More than } 10 \text { times }\end{array}$ \\
\hline Age $18+$ & $\begin{array}{c}0 \\
\text { Never }\end{array}$ & $\begin{array}{c}1 \\
\text { Once }\end{array}$ & $\begin{array}{c}2 \\
2-3 \text { times }\end{array}$ & $\begin{array}{c}3 \\
4-5 \text { times }\end{array}$ & $\begin{array}{c}4 \\
6-10 \\
\text { times }\end{array}$ & $\begin{array}{c}5 \\
\text { More than } 10 \text { times }\end{array}$ \\
\hline \multicolumn{7}{|c|}{ 5.Did you experience the divorce or separation of your parents? } \\
\hline Age 0 to 5 & $\begin{array}{c}0 \\
\text { Never }\end{array}$ & $\begin{array}{c}1 \\
\text { Once }\end{array}$ & $\begin{array}{c}2 \\
2-3 \text { times }\end{array}$ & $\begin{array}{c}3 \\
4-5 \text { times }\end{array}$ & $\begin{array}{c}4 \\
6-10 \\
\text { times } \\
\end{array}$ & $\begin{array}{c}5 \\
\text { More than } 10 \text { times }\end{array}$ \\
\hline Age 6 to 12 & $\begin{array}{c}0 \\
\text { Never }\end{array}$ & $\begin{array}{c}1 \\
\text { Once }\end{array}$ & $\begin{array}{c}2 \\
2-3 \text { times }\end{array}$ & $\begin{array}{c}3 \\
4-5 \text { times }\end{array}$ & $\begin{array}{c}4 \\
6-10 \\
\text { times }\end{array}$ & $\begin{array}{c}5 \\
\text { More than } 10 \text { times }\end{array}$ \\
\hline Age 13 to 18 & $\begin{array}{c}0 \\
\text { Never }\end{array}$ & $\begin{array}{c}1 \\
\text { Once }\end{array}$ & $\begin{array}{c}2 \\
2-3 \text { times }\end{array}$ & $\begin{array}{c}3 \\
4-5 \text { times }\end{array}$ & $\begin{array}{c}4 \\
6-10 \\
\text { times }\end{array}$ & $\begin{array}{c}5 \\
\text { More than } 10 \text { times }\end{array}$ \\
\hline Age $18+$ & $\begin{array}{c}0 \\
\text { Never }\end{array}$ & $\begin{array}{c}1 \\
\text { Once }\end{array}$ & $\begin{array}{c}2 \\
2-3 \text { times }\end{array}$ & $\begin{array}{c}3 \\
4-5 \text { times }\end{array}$ & $\begin{array}{c}4 \\
6-10 \\
\text { times } \\
\end{array}$ & $\begin{array}{c} \\
\text { More than } 10 \text { times }\end{array}$ \\
\hline \multicolumn{7}{|c|}{ 6.Did you experience the death or serious injury of a sibling? } \\
\hline Age 0 to 5 & $\begin{array}{c}0 \\
\text { Never }\end{array}$ & $\begin{array}{c}1 \\
\text { Once }\end{array}$ & $\begin{array}{c}2 \\
2-3 \text { times }\end{array}$ & $\begin{array}{c}3 \\
4-5 \text { times }\end{array}$ & $\begin{array}{c}4 \\
6-10 \\
\text { times } \\
\end{array}$ & $\begin{array}{c}5 \\
\text { More than } 10 \text { times }\end{array}$ \\
\hline Age 6 to 12 & $\begin{array}{c}0 \\
\text { Never }\end{array}$ & $\begin{array}{c}1 \\
\text { Once }\end{array}$ & $\begin{array}{c}2 \\
2-3 \text { times }\end{array}$ & $\begin{array}{c}3 \\
4-5 \text { times }\end{array}$ & $\begin{array}{c}4 \\
6-10 \\
\text { times } \\
\end{array}$ & $\begin{array}{c}5 \\
\text { More than } 10 \text { times }\end{array}$ \\
\hline Age 13 to 18 & $\begin{array}{c}0 \\
\text { Never }\end{array}$ & $\begin{array}{c}1 \\
\text { Once }\end{array}$ & $\begin{array}{c}2 \\
2-3 \text { times }\end{array}$ & $\begin{array}{c}3 \\
4-5 \text { times }\end{array}$ & $\begin{array}{c}4 \\
6-10 \\
\text { times }\end{array}$ & $\begin{array}{c}5 \\
\text { More than } 10 \text { times }\end{array}$ \\
\hline Age $18+$ & $\begin{array}{c}0 \\
\text { Never }\end{array}$ & $\begin{array}{c}1 \\
\text { Once }\end{array}$ & $\begin{array}{c}2 \\
2-3 \text { times }\end{array}$ & $\begin{array}{c}3 \\
4-5 \text { times }\end{array}$ & $\begin{array}{c}4 \\
6-10 \\
\text { times }\end{array}$ & $\begin{array}{c}5 \\
\text { More than } 10 \text { times }\end{array}$ \\
\hline \multicolumn{7}{|c|}{ 7.Did you ever experience the death or serious injury of a friend? } \\
\hline Age 0 to 5 & $\begin{array}{c}0 \\
\text { Never }\end{array}$ & $\begin{array}{c}1 \\
\text { Once }\end{array}$ & $\begin{array}{c}2 \\
2-3 \text { times }\end{array}$ & $\begin{array}{c}3 \\
4-5 \text { times }\end{array}$ & $\begin{array}{c}4 \\
6-10 \\
\text { times } \\
\end{array}$ & $\begin{array}{c}5 \\
\text { More than } 10 \text { times }\end{array}$ \\
\hline Age 6 to 12 & $\begin{array}{c}0 \\
\text { Never }\end{array}$ & $\begin{array}{c}1 \\
\text { Once }\end{array}$ & $\begin{array}{c}2 \\
2-3 \text { times }\end{array}$ & $\begin{array}{c}3 \\
4-5 \text { times }\end{array}$ & $\begin{array}{c} \\
6-10 \\
\text { times } \\
\end{array}$ & $\begin{array}{c}5 \\
\text { More than } 10 \text { times }\end{array}$ \\
\hline Age 13 to 18 & $\begin{array}{c}0 \\
\text { Never }\end{array}$ & $\begin{array}{c}1 \\
\text { Once }\end{array}$ & $\begin{array}{c}2 \\
2-3 \text { times }\end{array}$ & $\begin{array}{c}3 \\
4-5 \text { times }\end{array}$ & $\begin{array}{c}4 \\
6-10 \\
\text { times }\end{array}$ & $\begin{array}{c}5 \\
\text { More than } 10 \text { times }\end{array}$ \\
\hline Age $18+$ & $\begin{array}{c}0 \\
\text { Never }\end{array}$ & $\begin{array}{c}1 \\
\text { Once }\end{array}$ & $\begin{array}{c}2 \\
2-3 \text { times }\end{array}$ & $\begin{array}{c}3 \\
4-5 \text { times }\end{array}$ & $\begin{array}{c}4 \\
6-10 \\
\text { times } \\
\end{array}$ & $\begin{array}{c}5 \\
\text { More than } 10 \text { times }\end{array}$ \\
\hline \multicolumn{7}{|c|}{ 8.Did you ever witness violence towards others, including family members? } \\
\hline Age 0 to 5 & $\begin{array}{c}0 \\
\text { Never }\end{array}$ & $\begin{array}{c}1 \\
\text { Once }\end{array}$ & $\begin{array}{c}2 \\
2-3 \text { times }\end{array}$ & $\begin{array}{c}3 \\
4-5 \text { times }\end{array}$ & $\begin{array}{c}4 \\
6-10 \\
\text { times }\end{array}$ & $\begin{array}{c}5 \\
\text { More than } 10 \text { times }\end{array}$ \\
\hline Age 6 to 12 & 0 & 1 & 2 & 3 & 4 & 5 \\
\hline
\end{tabular}




\begin{tabular}{|c|c|c|c|c|c|c|}
\hline & Never & Once & $2-3$ times & 4-5 times & $\begin{array}{c}6-10 \\
\text { times } \\
\end{array}$ & More than 10 times \\
\hline Age 13 to 18 & $\begin{array}{c}0 \\
\text { Never }\end{array}$ & $\begin{array}{c}1 \\
\text { Once }\end{array}$ & $\begin{array}{c}2 \\
2-3 \text { times }\end{array}$ & $\begin{array}{c}3 \\
4-5 \text { times }\end{array}$ & $\begin{array}{c}4 \\
6-10 \\
\text { times }\end{array}$ & $\begin{array}{c}5 \\
\text { More than } 10 \text { times }\end{array}$ \\
\hline Age $18+$ & $\begin{array}{c}0 \\
\text { Never }\end{array}$ & $\begin{array}{c}1 \\
\text { Once }\end{array}$ & $\begin{array}{c}2 \\
2-3 \text { times }\end{array}$ & $\begin{array}{c}3 \\
4-5 \text { times }\end{array}$ & $\begin{array}{c}4 \\
6-10 \\
\text { times }\end{array}$ & $\begin{array}{c}5 \\
\text { More than } 10 \text { times }\end{array}$ \\
\hline \multicolumn{7}{|c|}{ 9.Did anyone in your family ever suffer from mental or psychiatric illness or have a "breakdown"? } \\
\hline Age 0 to 5 & $\begin{array}{c}0 \\
\text { Never }\end{array}$ & $\begin{array}{c}1 \\
\text { Once }\end{array}$ & $\begin{array}{c}2 \\
2-3 \text { times }\end{array}$ & $\begin{array}{c}3 \\
4-5 \text { times }\end{array}$ & $\begin{array}{c}4 \\
6-10 \\
\text { times }\end{array}$ & $\begin{array}{c}5 \\
\text { More than } 10 \text { times }\end{array}$ \\
\hline Age 6 to 12 & $\begin{array}{c}0 \\
\text { Never }\end{array}$ & $\begin{array}{c}1 \\
\text { Once }\end{array}$ & $\begin{array}{c}2 \\
2-3 \text { times }\end{array}$ & $\begin{array}{c}3 \\
4-5 \text { times }\end{array}$ & $\begin{array}{c}4 \\
6-10 \\
\text { times }\end{array}$ & $\begin{array}{c}5 \\
\text { More than } 10 \text { times }\end{array}$ \\
\hline Age 13 to 18 & $\begin{array}{c}0 \\
\text { Never }\end{array}$ & $\begin{array}{c}1 \\
\text { Once }\end{array}$ & $\begin{array}{c}2 \\
2-3 \text { times }\end{array}$ & $\begin{array}{c}3 \\
4-5 \text { times }\end{array}$ & $\begin{array}{c}4 \\
6-10 \\
\text { times }\end{array}$ & $\begin{array}{c}5 \\
\text { More than } 10 \text { times }\end{array}$ \\
\hline Age $18+$ & $\begin{array}{c}0 \\
\text { Never }\end{array}$ & $\begin{array}{c}1 \\
\text { Once }\end{array}$ & $\begin{array}{c}2 \\
2-3 \text { times }\end{array}$ & $\begin{array}{c}3 \\
4-5 \text { times }\end{array}$ & $\begin{array}{c}4 \\
6-10 \\
\text { times }\end{array}$ & $\begin{array}{c}5 \\
\text { More than } 10 \text { times }\end{array}$ \\
\hline \multicolumn{7}{|c|}{ 10. Did your parents or primary caretaker have a problem with alcoholism or drug abuse? } \\
\hline Age 0 to 5 & $\begin{array}{c}0 \\
\text { Never }\end{array}$ & $\begin{array}{c}1 \\
\text { Once }\end{array}$ & $\begin{array}{c}2 \\
2-3 \text { times }\end{array}$ & $\begin{array}{c}3 \\
4-5 \text { times }\end{array}$ & $\begin{array}{c}4 \\
6-10 \\
\text { times } \\
\end{array}$ & $\begin{array}{c}5 \\
\text { More than } 10 \text { times }\end{array}$ \\
\hline Age 6 to 12 & $\begin{array}{c}0 \\
\text { Never }\end{array}$ & $\begin{array}{c}1 \\
\text { Once }\end{array}$ & $\begin{array}{c}2 \\
2-3 \text { times }\end{array}$ & $\begin{array}{c}3 \\
4-5 \text { times }\end{array}$ & $\begin{array}{c}4 \\
6-10 \\
\text { times }\end{array}$ & $\begin{array}{c}5 \\
\text { More than } 10 \text { times }\end{array}$ \\
\hline Age 13 to 18 & $\begin{array}{c}0 \\
\text { Never }\end{array}$ & $\begin{array}{c}1 \\
\text { Once }\end{array}$ & $\begin{array}{c}2 \\
2-3 \text { times }\end{array}$ & $\begin{array}{c}3 \\
4-5 \text { times }\end{array}$ & $\begin{array}{c}4 \\
6-10 \\
\text { times } \\
\end{array}$ & $\begin{array}{l}5 \\
\text { More than } 10 \text { times }\end{array}$ \\
\hline Age $18+$ & $\begin{array}{c}0 \\
\text { Never }\end{array}$ & $\begin{array}{c}1 \\
\text { Once }\end{array}$ & $\begin{array}{c}2 \\
2-3 \text { times }\end{array}$ & $\begin{array}{c}3 \\
4-5 \text { times }\end{array}$ & $\begin{array}{c}4 \\
6-10 \\
\text { times }\end{array}$ & $\begin{array}{l}5 \\
\text { More than } 10 \text { times }\end{array}$ \\
\hline \multicolumn{7}{|c|}{ 11. Did you ever see someone murdered? } \\
\hline Age 0 to 5 & $\begin{array}{c}0 \\
\text { Never }\end{array}$ & $\begin{array}{c}1 \\
\text { Once }\end{array}$ & $\begin{array}{c}2 \\
2-3 \text { times }\end{array}$ & $\begin{array}{c}3 \\
4-5 \text { times }\end{array}$ & $\begin{array}{c}4 \\
6-10 \\
\text { times }\end{array}$ & $\begin{array}{c}5 \\
\text { More than } 10 \text { times }\end{array}$ \\
\hline Age 6 to 12 & $\begin{array}{c}0 \\
\text { Never }\end{array}$ & $\begin{array}{c}1 \\
\text { Once }\end{array}$ & $\begin{array}{c}2 \\
2-3 \text { times }\end{array}$ & $\begin{array}{c}3 \\
4-5 \text { times }\end{array}$ & $\begin{array}{c}4 \\
6-10 \\
\text { times }\end{array}$ & $\begin{array}{c}5 \\
\text { More than } 10 \text { times }\end{array}$ \\
\hline Age 13 to 18 & $\begin{array}{c}0 \\
\text { Never }\end{array}$ & $\begin{array}{c}1 \\
\text { Once }\end{array}$ & $\begin{array}{c}2 \\
2-3 \text { times }\end{array}$ & $\begin{array}{c}3 \\
4-5 \text { times }\end{array}$ & $\begin{array}{c}4 \\
6-10 \\
\text { times } \\
\end{array}$ & $\begin{array}{c}5 \\
\text { More than } 10 \text { times }\end{array}$ \\
\hline Age $18+$ & $\begin{array}{c}0 \\
\text { Never }\end{array}$ & $\begin{array}{c}1 \\
\text { Once }\end{array}$ & $\begin{array}{c}2 \\
2-3 \text { times }\end{array}$ & $\begin{array}{c}3 \\
4-5 \text { times }\end{array}$ & $\begin{array}{c}4 \\
6-10 \\
\text { times }\end{array}$ & $\begin{array}{c}5 \\
\text { More than } 10 \text { times }\end{array}$ \\
\hline
\end{tabular}

Part 2: Physical Punishment

1. Were you ever slapped in the face with an open hand?

\begin{tabular}{|l|c|c|c|c|c|c}
\hline Age 0 to 5 & 0 & 1 & 2 & 3 & 4 & 5 \\
& Never & Once & $2-3$ times & $4-5$ times & $\begin{array}{c}6-10 \\
\text { times }\end{array}$ & More than 10 times
\end{tabular}




\begin{tabular}{|c|c|c|c|c|c|c|}
\hline Age 6 to 12 & $\begin{array}{c}0 \\
\text { Never }\end{array}$ & $\begin{array}{c}1 \\
\text { Once }\end{array}$ & $\begin{array}{c}2 \\
2-3 \text { times }\end{array}$ & $\begin{array}{c}3 \\
4-5 \text { times }\end{array}$ & $\begin{array}{c}4 \\
6-10 \\
\text { times }\end{array}$ & $\begin{array}{c}5 \\
\text { More than } 10 \text { times }\end{array}$ \\
\hline Age 13 to 18 & $\begin{array}{c}0 \\
\text { Never }\end{array}$ & $\begin{array}{c}1 \\
\text { Once }\end{array}$ & $\begin{array}{c}2 \\
2-3 \text { times }\end{array}$ & $\begin{array}{c}3 \\
4-5 \text { times }\end{array}$ & $\begin{array}{c}4 \\
6-10 \\
\text { times }\end{array}$ & $\begin{array}{c}5 \\
\text { More than } 10 \text { times }\end{array}$ \\
\hline Age $18+$ & $\begin{array}{c}0 \\
\text { Never }\end{array}$ & $\begin{array}{c}1 \\
\text { Once }\end{array}$ & $\begin{array}{c}2 \\
2-3 \text { times }\end{array}$ & $\begin{array}{c}3 \\
4-5 \text { times }\end{array}$ & $\begin{array}{c}4 \\
6-10 \\
\text { times } \\
\end{array}$ & $\begin{array}{c}5 \\
\text { More than } 10 \text { times }\end{array}$ \\
\hline \multicolumn{7}{|c|}{ 2. Were you ever burned with hot water, a cigarette or something else? } \\
\hline Age 0 to 5 & $\begin{array}{c}0 \\
\text { Never }\end{array}$ & $\begin{array}{c}1 \\
\text { Once }\end{array}$ & $\begin{array}{c}2 \\
2-3 \text { times }\end{array}$ & $\begin{array}{c}3 \\
4-5 \text { times }\end{array}$ & $\begin{array}{c}4 \\
6-10 \\
\text { times }\end{array}$ & $\begin{array}{c}5 \\
\text { More than } 10 \text { times }\end{array}$ \\
\hline Age 6 to 12 & $\begin{array}{c}0 \\
\text { Never }\end{array}$ & $\begin{array}{c}1 \\
\text { Once }\end{array}$ & $\begin{array}{c}2 \\
2-3 \text { times }\end{array}$ & $\begin{array}{c}3 \\
4-5 \text { times }\end{array}$ & $\begin{array}{c}4 \\
6-10 \\
\text { times }\end{array}$ & $\begin{array}{c}5 \\
\text { More than } 10 \text { times }\end{array}$ \\
\hline Age 13 to 18 & $\begin{array}{c}0 \\
\text { Never }\end{array}$ & $\begin{array}{c}1 \\
\text { Once }\end{array}$ & $\begin{array}{c}2 \\
2-3 \text { times }\end{array}$ & $\begin{array}{c}3 \\
4-5 \text { times }\end{array}$ & $\begin{array}{c}4 \\
6-10 \\
\text { times }\end{array}$ & $\begin{array}{c}5 \\
\text { More than } 10 \text { times }\end{array}$ \\
\hline Age $18+$ & $\begin{array}{c}0 \\
\text { Never }\end{array}$ & $\begin{array}{c}1 \\
\text { Once }\end{array}$ & $\begin{array}{c}2 \\
2-3 \text { times }\end{array}$ & $\begin{array}{c}3 \\
4-5 \text { times }\end{array}$ & $\begin{array}{c}4 \\
6-10 \\
\text { times }\end{array}$ & $\begin{array}{c}5 \\
\text { More than } 10 \text { times }\end{array}$ \\
\hline \multicolumn{7}{|c|}{ 3.Were you ever punched or kicked? } \\
\hline Age 0 to 5 & $\begin{array}{c}0 \\
\text { Never }\end{array}$ & $\begin{array}{c}1 \\
\text { Once }\end{array}$ & $\begin{array}{c}2 \\
2-3 \text { times }\end{array}$ & $\begin{array}{c}3 \\
4-5 \text { times }\end{array}$ & $\begin{array}{c}4 \\
6-10 \\
\text { times }\end{array}$ & $\begin{array}{c}5 \\
\text { More than } 10 \text { times }\end{array}$ \\
\hline Age 6 to 12 & $\begin{array}{c}0 \\
\text { Never }\end{array}$ & $\begin{array}{c}1 \\
\text { Once }\end{array}$ & $\begin{array}{c}2 \\
2-3 \text { times }\end{array}$ & $\begin{array}{c}3 \\
4-5 \text { times }\end{array}$ & $\begin{array}{c}4 \\
6-10 \\
\text { times } \\
\end{array}$ & $\begin{array}{c}5 \\
\text { More than } 10 \text { times }\end{array}$ \\
\hline Age 13 to 18 & $\begin{array}{c}0 \\
\text { Never }\end{array}$ & $\begin{array}{c}1 \\
\text { Once }\end{array}$ & $\begin{array}{c}2 \\
2-3 \text { times }\end{array}$ & $\begin{array}{c}3 \\
4-5 \text { times }\end{array}$ & $\begin{array}{c}4 \\
6-10 \\
\text { times }\end{array}$ & $\begin{array}{c}5 \\
\text { More than } 10 \text { times }\end{array}$ \\
\hline Age $18+$ & $\begin{array}{c}0 \\
\text { Never }\end{array}$ & $\begin{array}{c}1 \\
\text { Once }\end{array}$ & $\begin{array}{c}2 \\
2-3 \text { times }\end{array}$ & $\begin{array}{c}3 \\
4-5 \text { times }\end{array}$ & $\begin{array}{c}4 \\
6-10 \\
\text { times } \\
\end{array}$ & $\begin{array}{c}5 \\
\text { More than } 10 \text { times }\end{array}$ \\
\hline \multicolumn{7}{|c|}{ 4. Were you ever hit with an object that was thrown at you? } \\
\hline Age 0 to 5 & $\begin{array}{c}0 \\
\text { Never }\end{array}$ & $\begin{array}{c}1 \\
\text { Once }\end{array}$ & $\begin{array}{c}2 \\
2-3 \text { times }\end{array}$ & $\begin{array}{c}3 \\
4-5 \text { times }\end{array}$ & $\begin{array}{c}4 \\
6-10 \\
\text { times } \\
\end{array}$ & $\begin{array}{c}5 \\
\text { More than } 10 \text { times }\end{array}$ \\
\hline Age 6 to 12 & $\begin{array}{c}0 \\
\text { Never }\end{array}$ & $\begin{array}{c}1 \\
\text { Once }\end{array}$ & $\begin{array}{c}2 \\
2-3 \text { times }\end{array}$ & $\begin{array}{c}3 \\
4-5 \text { times }\end{array}$ & $\begin{array}{c}4 \\
6-10 \\
\text { times }\end{array}$ & $\begin{array}{c}5 \\
\text { More than } 10 \text { times }\end{array}$ \\
\hline Age 13 to 18 & $\begin{array}{c}0 \\
\text { Never }\end{array}$ & $\begin{array}{c}1 \\
\text { Once }\end{array}$ & $\begin{array}{c}2 \\
2-3 \text { times }\end{array}$ & $\begin{array}{c}3 \\
4-5 \text { times }\end{array}$ & $\begin{array}{c}4 \\
6-10 \\
\text { times } \\
\end{array}$ & $\begin{array}{c}5 \\
\text { More than } 10 \text { times }\end{array}$ \\
\hline Age $18+$ & $\begin{array}{c}0 \\
\text { Never }\end{array}$ & $\begin{array}{c}1 \\
\text { Once }\end{array}$ & $\begin{array}{c}2 \\
2-3 \text { times }\end{array}$ & $\begin{array}{c}3 \\
4-5 \text { times }\end{array}$ & $\begin{array}{c}4 \\
6-10 \\
\text { times }\end{array}$ & $\begin{array}{c}5 \\
\text { More than } 10 \text { times }\end{array}$ \\
\hline \multicolumn{7}{|c|}{ 5.Were you ever pushed or shoved? } \\
\hline Age 0 to 5 & $\begin{array}{c}0 \\
\text { Never }\end{array}$ & $\begin{array}{c}1 \\
\text { Once }\end{array}$ & $\begin{array}{c}2 \\
2-3 \text { times }\end{array}$ & $\begin{array}{c}3 \\
4-5 \text { times }\end{array}$ & $\begin{array}{c}4 \\
6-10 \\
\text { times }\end{array}$ & $\begin{array}{c}5 \\
\text { More than } 10 \text { times }\end{array}$ \\
\hline Age 6 to 12 & $\begin{array}{c}0 \\
\text { Never }\end{array}$ & $\begin{array}{c}1 \\
\text { Once }\end{array}$ & $\begin{array}{c}2 \\
2-3 \text { times }\end{array}$ & $\begin{array}{c}3 \\
4-5 \text { times }\end{array}$ & $\begin{array}{c}4 \\
6-10\end{array}$ & $\begin{array}{c}5 \\
\text { More than } 10 \text { times }\end{array}$ \\
\hline
\end{tabular}




\begin{tabular}{l|c|c|c|c|c|c} 
& & & & times & \\
\hline Age 13 to 18 & 0 & 1 & 2 & 3 & 4 & 5 \\
& Never & Once & $2-3$ times & $\begin{array}{c}3-5 \text { times } \\
6-10 \\
\text { times }\end{array}$ & More than 10 times \\
\hline Age 18+ & 0 & 1 & 2 & 3 & 4 & 5 \\
& Never & Once & $2-3$ times & $\begin{array}{c}4-5 \text { times } \\
6-10 \\
\text { times }\end{array}$ & More than 10 times
\end{tabular}

Part 3: Emotional Abuse

1. Were you often put down or ridiculed?

\begin{tabular}{|c|c|c|c|c|c|c|}
\hline Age 0 to 5 & $\begin{array}{c}0 \\
\text { Never }\end{array}$ & $\begin{array}{c}1 \\
\text { Once }\end{array}$ & $\begin{array}{c}2 \\
2-3 \text { times }\end{array}$ & $\begin{array}{c}3 \\
4-5 \text { times }\end{array}$ & $\begin{array}{c}4 \\
6-10 \\
\text { times }\end{array}$ & $\begin{array}{c}5 \\
\text { More than } 10 \text { times }\end{array}$ \\
\hline Age 6 to 12 & $\begin{array}{c}0 \\
\text { Never }\end{array}$ & $\begin{array}{c}1 \\
\text { Once }\end{array}$ & $\begin{array}{c}2 \\
2-3 \text { times }\end{array}$ & $\begin{array}{c}3 \\
4-5 \text { times }\end{array}$ & $\begin{array}{c}4 \\
6-10 \\
\text { times }\end{array}$ & $\begin{array}{c}5 \\
\text { More than } 10 \text { times }\end{array}$ \\
\hline Age 13 to 18 & $\begin{array}{c}0 \\
\text { Never }\end{array}$ & $\begin{array}{c}1 \\
\text { Once }\end{array}$ & $\begin{array}{c}2 \\
2-3 \text { times }\end{array}$ & $\begin{array}{c}3 \\
4-5 \text { times }\end{array}$ & $\begin{array}{c}4 \\
6-10 \\
\text { times }\end{array}$ & $\begin{array}{c}5 \\
\text { More than } 10 \text { times }\end{array}$ \\
\hline Age $18+$ & $\begin{array}{c}0 \\
\text { Never }\end{array}$ & $\begin{array}{c}1 \\
\text { Once }\end{array}$ & $\begin{array}{c}2 \\
2-3 \text { times }\end{array}$ & $\begin{array}{c}3 \\
4-5 \text { times }\end{array}$ & $\begin{array}{c}4 \\
6-10 \\
\text { times }\end{array}$ & $\begin{array}{c}5 \\
\text { More than } 10 \text { times }\end{array}$ \\
\hline \multicolumn{7}{|c|}{ 2. Were you often ignored or made to feel that you didn't count? } \\
\hline Age 0 to 5 & $\begin{array}{c}0 \\
\text { Never }\end{array}$ & $\begin{array}{c}1 \\
\text { Once }\end{array}$ & $\begin{array}{c}2 \\
2-3 \text { times }\end{array}$ & $\begin{array}{c}3 \\
4-5 \text { times }\end{array}$ & $\begin{array}{c}4 \\
6-10 \\
\text { times } \\
\end{array}$ & $\begin{array}{c}5 \\
\text { More than } 10 \text { times }\end{array}$ \\
\hline Age 6 to 12 & $\begin{array}{c}0 \\
\text { Never }\end{array}$ & $\begin{array}{c}1 \\
\text { Once }\end{array}$ & $\begin{array}{c}2 \\
2-3 \text { times }\end{array}$ & $\begin{array}{c}3 \\
4-5 \text { times }\end{array}$ & $\begin{array}{c}4 \\
6-10 \\
\text { times }\end{array}$ & $\begin{array}{c}5 \\
\text { More than } 10 \text { times }\end{array}$ \\
\hline Age 13 to 18 & $\begin{array}{c}0 \\
\text { Never }\end{array}$ & $\begin{array}{c}1 \\
\text { Once }\end{array}$ & $\begin{array}{c}2 \\
2-3 \text { times }\end{array}$ & $\begin{array}{c}3 \\
4-5 \text { times }\end{array}$ & $\begin{array}{c}4 \\
6-10 \\
\text { times } \\
\end{array}$ & $\begin{array}{c}5 \\
\text { More than } 10 \text { times }\end{array}$ \\
\hline Age $18+$ & $\begin{array}{c}0 \\
\text { Never }\end{array}$ & $\begin{array}{c}1 \\
\text { Once }\end{array}$ & $\begin{array}{c}2 \\
2-3 \text { times }\end{array}$ & $\begin{array}{c}3 \\
4-5 \text { times }\end{array}$ & $\begin{array}{c}4 \\
6-10 \\
\text { times }\end{array}$ & $\begin{array}{c}5 \\
\text { More than } 10 \text { times }\end{array}$ \\
\hline
\end{tabular}

\begin{tabular}{|c|c|c|c|c|c|c|}
\hline \multicolumn{7}{|c|}{ 3. Were you often told you were no good? } \\
\hline Age 0 to 5 & $\begin{array}{c}0 \\
\text { Never }\end{array}$ & $\begin{array}{c}1 \\
\text { Once }\end{array}$ & $\begin{array}{c}2 \\
2-3 \text { times }\end{array}$ & $\begin{array}{c}3 \\
4-5 \text { times }\end{array}$ & $\begin{array}{c}4 \\
6-10 \\
\text { times }\end{array}$ & $\begin{array}{c}5 \\
\text { More than } 10 \text { times }\end{array}$ \\
\hline Age 6 to 12 & $\begin{array}{c}0 \\
\text { Never }\end{array}$ & $\begin{array}{c}1 \\
\text { Once }\end{array}$ & $\begin{array}{c}2 \\
2-3 \text { times }\end{array}$ & $\begin{array}{c}3 \\
4-5 \text { times }\end{array}$ & $\begin{array}{c}4 \\
6-10 \\
\text { times }\end{array}$ & $\begin{array}{c}5 \\
\text { More than } 10 \text { times }\end{array}$ \\
\hline Age 13 to 18 & $\begin{array}{c}0 \\
\text { Never }\end{array}$ & $\begin{array}{c}1 \\
\text { Once }\end{array}$ & $\begin{array}{c}2 \\
2-3 \text { times }\end{array}$ & $\begin{array}{c}3 \\
4-5 \text { times }\end{array}$ & $\begin{array}{c}4 \\
6-10 \\
\text { times }\end{array}$ & $\begin{array}{c}5 \\
\text { More than } 10 \text { times }\end{array}$ \\
\hline Age $18+$ & $\begin{array}{c}0 \\
\text { Never }\end{array}$ & $\begin{array}{c}1 \\
\text { Once }\end{array}$ & $\begin{array}{c}2 \\
2-3 \text { times }\end{array}$ & $\begin{array}{c}3 \\
4-5 \text { times }\end{array}$ & $\begin{array}{c}4 \\
6-10 \\
\text { times }\end{array}$ & $\begin{array}{c}5 \\
\text { More than } 10 \text { times }\end{array}$ \\
\hline
\end{tabular}

\begin{tabular}{|c|c|c|c|c|c|c|}
\hline & $\operatorname{tr}$ & $\mathrm{nac}$ & ncaring wa & or made to & like yo & e not loved? \\
\hline Age 0 to 5 & $\begin{array}{c}0 \\
\text { Never }\end{array}$ & $\begin{array}{c}1 \\
\text { Once }\end{array}$ & $\begin{array}{c}2 \\
2-3 \text { times }\end{array}$ & $\begin{array}{c}3 \\
4-5 \text { times }\end{array}$ & $\begin{array}{c}4 \\
6-10 \\
\text { times }\end{array}$ & $\begin{array}{c}5 \\
\text { More than } 10 \text { times }\end{array}$ \\
\hline Age & $\begin{array}{c}0 \\
\text { Never }\end{array}$ & $\begin{array}{c}1 \\
\text { Once }\end{array}$ & $\begin{array}{c}2 \\
2-3 \text { times }\end{array}$ & $\begin{array}{c}3 \\
4-5 \text { times }\end{array}$ & $\begin{array}{c}4 \\
6-10\end{array}$ & $\begin{array}{c}5 \\
\text { More than } 10 \text { times }\end{array}$ \\
\hline
\end{tabular}




\begin{tabular}{|c|c|c|c|c|c|c|}
\hline & & & & & times & \\
\hline Age 13 to 18 & $\begin{array}{c}0 \\
\text { Never }\end{array}$ & $\begin{array}{c}1 \\
\text { Once }\end{array}$ & $\begin{array}{c}2 \\
2-3 \text { times }\end{array}$ & $\begin{array}{c}3 \\
4-5 \text { times }\end{array}$ & $\begin{array}{c}4 \\
6-10 \\
\text { times }\end{array}$ & $\begin{array}{c}5 \\
\text { More than } 10 \text { times }\end{array}$ \\
\hline Age $18+$ & $\begin{array}{c}0 \\
\text { Never }\end{array}$ & $\begin{array}{c}1 \\
\text { Once }\end{array}$ & $\begin{array}{c}2 \\
2-3 \text { times }\end{array}$ & $\begin{array}{c}3 \\
4-5 \text { times }\end{array}$ & $\begin{array}{c}4 \\
6-10 \\
\text { times } \\
\end{array}$ & $\begin{array}{c}5 \\
\text { More than } 10 \text { times }\end{array}$ \\
\hline \multicolumn{7}{|c|}{ 5. Did your parents or caretakers often fail to understand you or your needs? } \\
\hline Age 0 to 5 & $\begin{array}{c}0 \\
\text { Never }\end{array}$ & $\begin{array}{c}1 \\
\text { Once }\end{array}$ & $\begin{array}{c}2 \\
2-3 \text { times }\end{array}$ & $\begin{array}{c}3 \\
4-5 \text { times }\end{array}$ & $\begin{array}{c}4 \\
6-10 \\
\text { times }\end{array}$ & $\begin{array}{c}5 \\
\text { More than } 10 \text { times }\end{array}$ \\
\hline Age 6 to 12 & $\begin{array}{c}0 \\
\text { Never }\end{array}$ & $\begin{array}{c}1 \\
\text { Once }\end{array}$ & $\begin{array}{c}2 \\
2-3 \text { times }\end{array}$ & $\begin{array}{c}3 \\
4-5 \text { times }\end{array}$ & $\begin{array}{c}4 \\
6-10 \\
\text { times }\end{array}$ & $\begin{array}{c}5 \\
\text { More than } 10 \text { times }\end{array}$ \\
\hline Age 13 to 18 & $\begin{array}{c}0 \\
\text { Never }\end{array}$ & $\begin{array}{c}1 \\
\text { Once }\end{array}$ & $\begin{array}{c}2 \\
2-3 \text { times }\end{array}$ & $\begin{array}{c}3 \\
4-5 \text { times }\end{array}$ & $\begin{array}{c}4 \\
6-10 \\
\text { times }\end{array}$ & $\begin{array}{c}5 \\
\text { More than } 10 \text { times }\end{array}$ \\
\hline Age $18+$ & $\begin{array}{c}0 \\
\text { Never }\end{array}$ & $\begin{array}{c}1 \\
\text { Once }\end{array}$ & $\begin{array}{c}2 \\
2-3 \text { times }\end{array}$ & $\begin{array}{c}3 \\
4-5 \text { times }\end{array}$ & $\begin{array}{c}4 \\
6-10 \\
\text { times }\end{array}$ & $\begin{array}{c}5 \\
\text { More than } 10 \text { times }\end{array}$ \\
\hline
\end{tabular}

\section{Part 4: Sexual Events}

1. Were you ever touched in an intimate or private part of your body (e.g. breast, thighs, genitals) in a way that surprised you or made you feel uncomfortable?

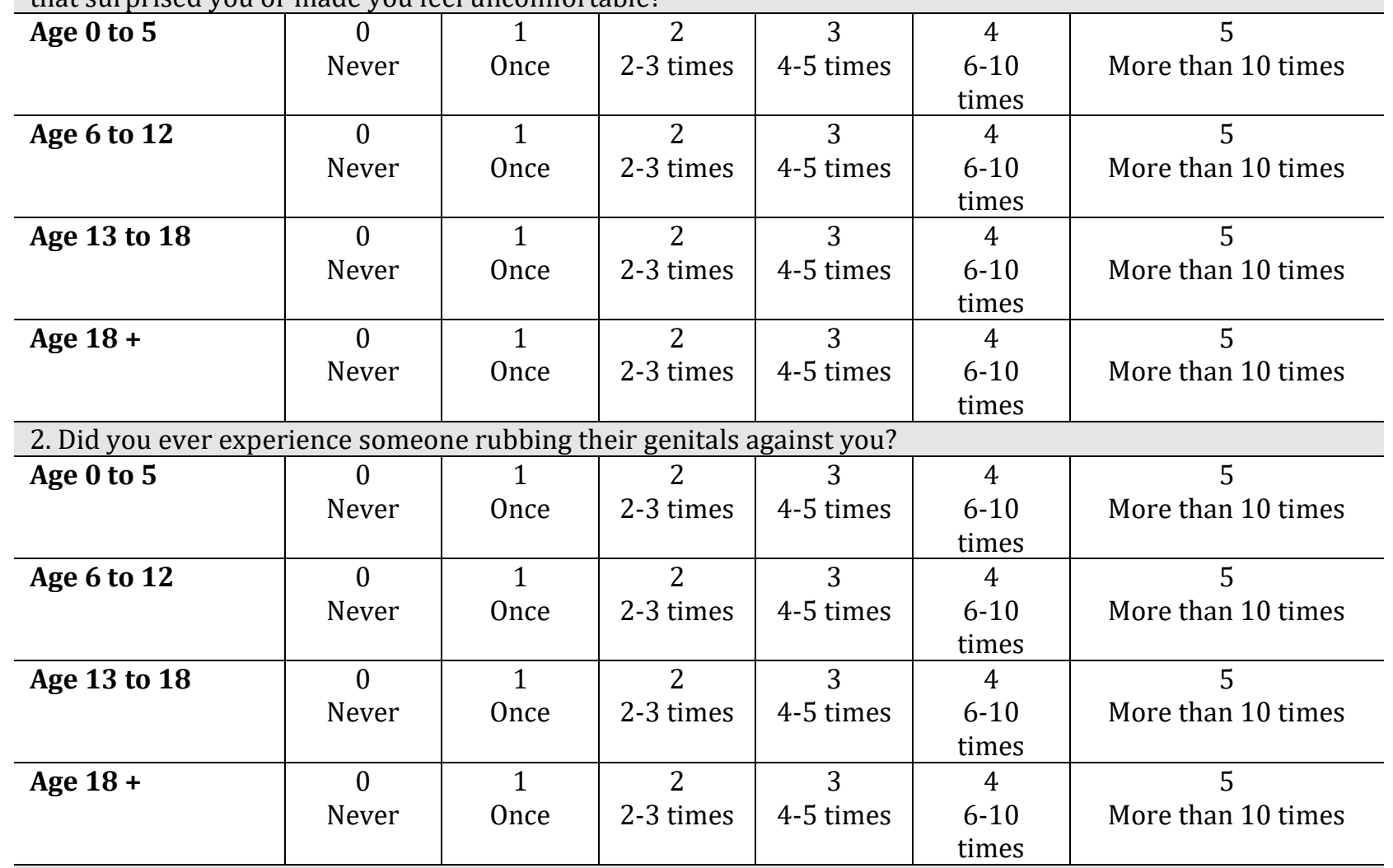

3. Were you ever forced or coerced to touch another person in an intimate or private part of their body?

\begin{tabular}{|l|l|l|l|l|l|l|}
\hline Age 0 to 5 & 0 & 1 & 2 & 3 & 4 & 5
\end{tabular}




\begin{tabular}{|c|c|c|c|c|c|c|}
\hline & Never & Once & $2-3$ times & 4-5 times & $\begin{array}{c}6-10 \\
\text { times }\end{array}$ & More than 10 times \\
\hline Age 6 to 12 & $\begin{array}{c}0 \\
\text { Never }\end{array}$ & $\begin{array}{c}1 \\
\text { Once }\end{array}$ & $\begin{array}{c}2 \\
2-3 \text { times }\end{array}$ & $\begin{array}{c}3 \\
4-5 \text { times }\end{array}$ & $\begin{array}{c}4 \\
6-10 \\
\text { times }\end{array}$ & $\begin{array}{c}5 \\
\text { More than } 10 \text { times }\end{array}$ \\
\hline Age 13 to 18 & $\begin{array}{c}0 \\
\text { Never }\end{array}$ & $\begin{array}{c}1 \\
\text { Once }\end{array}$ & $\begin{array}{c}2 \\
2-3 \text { times }\end{array}$ & $\begin{array}{c}3 \\
4-5 \text { times }\end{array}$ & $\begin{array}{c}4 \\
6-10 \\
\text { times } \\
\end{array}$ & $\begin{array}{c}5 \\
\text { More than } 10 \text { times }\end{array}$ \\
\hline Age $18+$ & $\begin{array}{c}0 \\
\text { Never }\end{array}$ & $\begin{array}{c}1 \\
\text { Once }\end{array}$ & $\begin{array}{c}2 \\
2-3 \text { times }\end{array}$ & $\begin{array}{c}3 \\
4-5 \text { times }\end{array}$ & $\begin{array}{c}4 \\
6-10 \\
\text { times } \\
\end{array}$ & $\begin{array}{c}5 \\
\text { More than } 10 \text { times }\end{array}$ \\
\hline \multicolumn{7}{|c|}{ 4. Did anyone ever have genital sex with you against your will? } \\
\hline Age 0 to 5 & $\begin{array}{c}0 \\
\text { Never }\end{array}$ & $\begin{array}{c}1 \\
\text { Once }\end{array}$ & $\begin{array}{c}2 \\
2-3 \text { times }\end{array}$ & $\begin{array}{c}3 \\
4-5 \text { times }\end{array}$ & $\begin{array}{c}4 \\
6-10 \\
\text { times }\end{array}$ & $\begin{array}{c}5 \\
\text { More than } 10 \text { times }\end{array}$ \\
\hline Age 6 to 12 & $\begin{array}{c}0 \\
\text { Never }\end{array}$ & $\begin{array}{c}1 \\
\text { Once }\end{array}$ & $\begin{array}{c}2 \\
2-3 \text { times }\end{array}$ & $\begin{array}{c}3 \\
4-5 \text { times }\end{array}$ & $\begin{array}{c}4 \\
6-10 \\
\text { times } \\
\end{array}$ & $\begin{array}{c}5 \\
\text { More than } 10 \text { times }\end{array}$ \\
\hline Age 13 to 18 & $\begin{array}{c}0 \\
\text { Never }\end{array}$ & $\begin{array}{c}1 \\
\text { Once }\end{array}$ & $\begin{array}{c}2 \\
2-3 \text { times }\end{array}$ & $\begin{array}{c}3 \\
4-5 \text { times }\end{array}$ & $\begin{array}{c}4 \\
6-10 \\
\text { times } \\
\end{array}$ & $\begin{array}{c}5 \\
\text { More than } 10 \text { times }\end{array}$ \\
\hline Age $18+$ & $\begin{array}{c}0 \\
\text { Never }\end{array}$ & $\begin{array}{c}1 \\
\text { Once }\end{array}$ & $\begin{array}{c}2 \\
2-3 \text { times }\end{array}$ & $\begin{array}{c}3 \\
4-5 \text { times }\end{array}$ & $\begin{array}{c}4 \\
6-10 \\
\text { times } \\
\end{array}$ & $\begin{array}{c}5 \\
\text { More than } 10 \text { times }\end{array}$ \\
\hline \multicolumn{7}{|c|}{ 5. Were you ever forced or coerced to perform oral sex on someone against your will? } \\
\hline Age 0 to 5 & $\begin{array}{c}0 \\
\text { Never }\end{array}$ & $\begin{array}{c}1 \\
\text { Once }\end{array}$ & $\begin{array}{c}2 \\
2-3 \text { times }\end{array}$ & $\begin{array}{c}3 \\
4-5 \text { times }\end{array}$ & $\begin{array}{c}4 \\
6-10 \\
\text { times }\end{array}$ & $\begin{array}{c}5 \\
\text { More than } 10 \text { times }\end{array}$ \\
\hline Age 6 to 12 & $\begin{array}{c}0 \\
\text { Never }\end{array}$ & $\begin{array}{c}1 \\
\text { Once }\end{array}$ & $\begin{array}{c}2 \\
2-3 \text { times }\end{array}$ & $\begin{array}{c}3 \\
4-5 \text { times }\end{array}$ & $\begin{array}{c}4 \\
6-10 \\
\text { times } \\
\end{array}$ & $\begin{array}{c}5 \\
\text { More than } 10 \text { times }\end{array}$ \\
\hline Age 13 to 18 & $\begin{array}{c}0 \\
\text { Never }\end{array}$ & $\begin{array}{c}1 \\
\text { Once }\end{array}$ & $\begin{array}{c}2 \\
2-3 \text { times }\end{array}$ & $\begin{array}{c}3 \\
4-5 \text { times }\end{array}$ & $\begin{array}{c}4 \\
6-10 \\
\text { times } \\
\end{array}$ & $\begin{array}{c}5 \\
\text { More than } 10 \text { times }\end{array}$ \\
\hline Age $18+$ & $\begin{array}{c}0 \\
\text { Never }\end{array}$ & $\begin{array}{c}1 \\
\text { Once }\end{array}$ & $\begin{array}{c}2 \\
2-3 \text { times }\end{array}$ & $\begin{array}{c}3 \\
4-5 \text { times }\end{array}$ & $\begin{array}{c}4 \\
6-10 \\
\text { times } \\
\end{array}$ & $\begin{array}{c}5 \\
\text { More than } 10 \text { times }\end{array}$ \\
\hline \multicolumn{7}{|c|}{ 6. Were you ever forced or coerced to kiss someone in a sexual rather than an affectionate way? } \\
\hline Age 0 to 5 & $\begin{array}{c}0 \\
\text { Never }\end{array}$ & $\begin{array}{c}1 \\
\text { Once }\end{array}$ & $\begin{array}{c}2 \\
2-3 \text { times }\end{array}$ & $\begin{array}{c}3 \\
4-5 \text { times }\end{array}$ & $\begin{array}{c}4 \\
6-10 \\
\text { times } \\
\end{array}$ & $\begin{array}{c}5 \\
\text { More than } 10 \text { times }\end{array}$ \\
\hline Age 6 to 12 & $\begin{array}{c}0 \\
\text { Never }\end{array}$ & $\begin{array}{c}1 \\
\text { Once }\end{array}$ & $\begin{array}{c}2 \\
2-3 \text { times }\end{array}$ & $\begin{array}{c}3 \\
4-5 \text { times }\end{array}$ & $\begin{array}{c}4 \\
6-10 \\
\text { times } \\
\end{array}$ & $\begin{array}{c}5 \\
\text { More than } 10 \text { times }\end{array}$ \\
\hline Age 13 to 18 & $\begin{array}{c}0 \\
\text { Never }\end{array}$ & $\begin{array}{c}1 \\
\text { Once }\end{array}$ & $\begin{array}{c}2 \\
2-3 \text { times }\end{array}$ & $\begin{array}{c}3 \\
4-5 \text { times }\end{array}$ & $\begin{array}{c}4 \\
6-10 \\
\text { times } \\
\end{array}$ & $\begin{array}{c}5 \\
\text { More than } 10 \text { times }\end{array}$ \\
\hline Age $18+$ & $\begin{array}{c}0 \\
\text { Never }\end{array}$ & $\begin{array}{c}1 \\
\text { Once }\end{array}$ & $\begin{array}{c}2 \\
2-3 \text { times }\end{array}$ & $\begin{array}{c}3 \\
4-5 \text { times }\end{array}$ & $\begin{array}{c}4 \\
6-10 \\
\text { times }\end{array}$ & $\begin{array}{c}5 \\
\text { More than } 10 \text { times }\end{array}$ \\
\hline
\end{tabular}




\section{Appendix I: Beck Depression Inventory}

\section{Beck Depression Inventory (BDI) - 21 item scale}

On this questionnaire are groups of statements. Please read the entire group of statements in each category. Then pick out $\underline{\mathrm{ONE}}$ statement in that group which best describes the way you feel. Check off the number beside the statement you have chosen.

1. $\_0$ = I do not feel sad

$\ldots 1$ = I feel sad or blue

$\ldots 2 \mathrm{a}=\mathrm{I}$ am blue or sad all of the time and I can't snap out of it

_ $2 \mathrm{~b}=\mathrm{I}$ am so sad or unhappy that it is very painful

$\ldots 3$ = I am so sad or unhappy that I can't stand it

2. $\_0=$ I am not particularly pessimistic or discouraged about the future

$-1=$ I feel discouraged about the future

- $2 \mathrm{a}=$ I feel I have nothing to look forward to

$\ldots 2 \mathrm{~b}=\mathrm{I}$ feel I won't ever get over my troubles

$\ldots 3=\mathrm{I}$ feel that the future is hopeless and things cannot improve

3. $\_0=$ I do not feel like a failure

1 = I feel I have failed more than the average person

_ $2 \mathrm{a}=$ I feel I have accomplished very little that is worthwhile or that means anything

$\ldots 2 \mathrm{~b}=$ As I look back on my life, all I can see is a lot of failures

$\ldots 3=$ I feel I am a complete failure as a person

4. $\_0=\mathrm{I}$ am not particularly dissatisfied

$1 \mathrm{a}=\mathrm{I}$ feel bored most of the time

$-1 \mathrm{~b}=\mathrm{I}$ don't enjoy things the way I used to

_- 2 = I don't get satisfaction out of anything anymore

$\ldots 3=\mathrm{I}$ am dissatisfied with everything

5. $\_0=$ I don't feel particularly guilty

$\ldots 1=$ I feel bad or unworthy a good part of the time

$-2 \mathrm{a}=\mathrm{I}$ feel quite guilty

$\ldots$ _ $b=$ I feel bad or unworthy practically all of the time now

_ 3 = I feel as though I am very bad or worthless

6. $\_0$ = I don't feel I am being punished

$-1=\mathrm{I}$ have a feeling that something bad may happen to me

$\ldots 2=$ I feel I am being punished or will be punished

- $3 \mathrm{a}=\mathrm{I}$ feel I deserve to be punished 
$\ldots 3 \mathrm{~b}=\mathrm{I}$ want to be punished

7. $\_0=$ I don't feel disappointed in myself

$\ldots 1 \mathrm{a}=\mathrm{I}$ am disappointed in myself

$\ldots 1 \mathrm{~b}=\mathrm{I}$ don't like myself

$\ldots 2=\mathrm{I}$ am disgusted with myself

$\ldots 3$ = I hate myself

8. $\_0=$ I do not feel I am any worse than anybody else

_ 1 = I am very critical of myself for my weaknesses or mistakes

$\ldots 2 \mathrm{a}=$ I blame myself for everything that goes wrong

$\ldots 2 b=$ I feel I have many bad faults

9. $\_0=$ I don't have thoughts of harming myself

_ 1 = I have thoughts of harming myself but I would not carry them out

$-2 \mathrm{a}=\mathrm{I}$ feel I would be better off dead

$\ldots 2 b=$ I have definite plans about committing suicide

$\ldots 2 c=$ I feel my family would be better off if I were dead

$\ldots 3$ = I would kill myself if I could

10. $\_0=I$ don't cry anymore than usual

$\ldots 1=$ I cry more now than I used to

_ $2=$ I cry all the time now. I can't stop it

$\ldots 3=$ I used to be able to cry but now I can't cry at all even though I want to

11. $\_0$ = I am no more irritable than usual

1 = I am more irritable than usual

$2=$ I am much more irritable than usual

$-3=$ I am irritable all the time

12. $\_$_ $=$I have not lost interest in other people

$1=\mathrm{I}$ am less interested in other people than I used to be

2 = I have lost most of my interest in other people and I have little feeling for them

_ 3 = I have lost all my interest in other people and don't care about them at all

13. $\_0$ = I make decisions about as well as ever

$1=\mathrm{I}$ am less sure of myself now and try to put off making decisions

$\ldots 2$ = I can't make decisions anymore without help

_ 3 = I can't make decisions at all anymore

14. _ $0=$ I don't feel I look any worse than I used to

1 = I am worried that I am looking old or unattractive

$\ldots 2=$ I feel that there are permanent changes in my appearance and they make me look unattractive

$\ldots 3=$ I feel that I am ugly or repulsive looking 
15. $\_0$ = I can work about as well as before

$\ldots 1 \mathrm{a}=$ It takes extra effort to get started at doing something

$1 \mathrm{~b}=\mathrm{I}$ don't work as well as I used to

2 = I have to push myself very hard to do anything

_3 = I can't do any work at all

16. _ $0=$ I can sleep as well as usual

$1=$ I wake up more tired in the morning than I used to

$-2=$ I wake up 1-2 hours earlier than usual and find it hard to get back to sleep

_ 3 = I wake up early every day and can't get more than 5 hours sleep

17. $\_0=$ I don't get anymore tired than usual

$1=$ I get tired more easily than I used to

$\ldots 2=$ I get tired from doing anything

__ $3=$ I get too tired to do anything

18. _ $0=$ My appetite is no worse than usual

$1=$ My appetite is not as good as it used to be

_- 2 = My appetite is much worse now

$\ldots 3=$ I have no appetite at all any more

19. _ 0 = I haven't lost much weight, if any, lately

1 = I have lost more than 5 pounds

2 = I have lost more than 10 pounds

$\ldots 3=$ I have lost more than 15 pounds

20. $\_0=\mathrm{I}$ am no more concerned about my health than usual

$1=\mathrm{I}$ am concerned about aches and pains or upset stomach or constipation or other unpleasant feelings in my body

$\ldots 2$ = I am so concerned with how I feel or what I feel that it's hard to think of much else

$\ldots 3=$ I am completely absorbed in what I feel

21. $\_0=$ I have not noticed any recent change in my interest in sex

$-1=\mathrm{I}$ am less interested in sex than I used to be

2 = I am much less interested in sex now

- 3 = I have lost interest in sex completely 
Appendix I: Additional Computer Tasks

Iowa Gambling Task

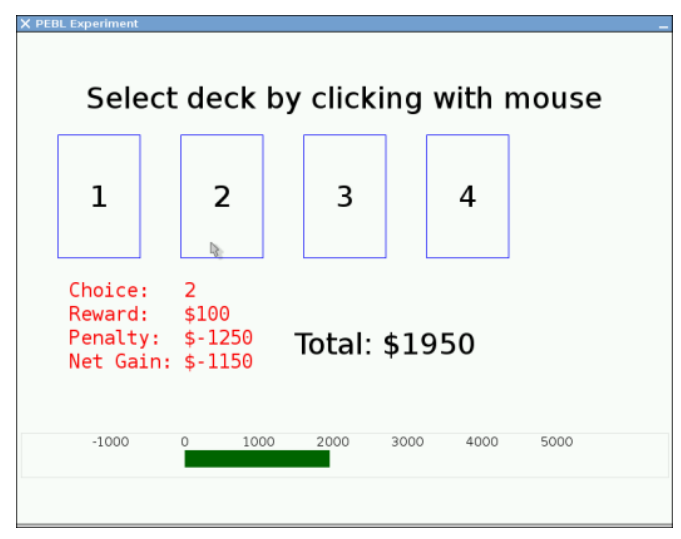

Go/No Go Task

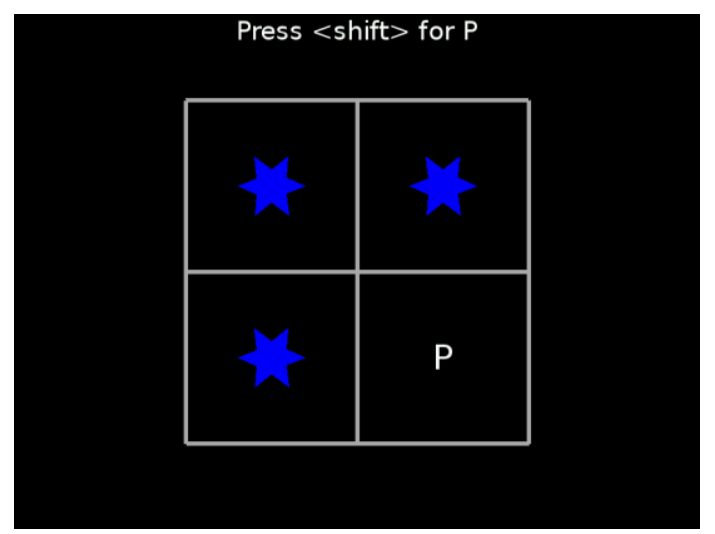




\section{$\underline{\text { Appendix K: Additional Measures }}$}

\section{Cognitive Flexibility Questionnaire (CFQ)}

The purpose of this questionnaire is to determine what individuals generally think, feel, and do when experiencing stressful situations. Of course, you may respond differently depending on the situation, but think of what you usually do when you are under a lot of stress. Using the scale below, indicate the extent to which agree or disagree with the following statements. Please answer according to what you actually think/feel/do rather than what you think is the correct response.

\begin{tabular}{ccccccc}
$\begin{array}{c}\text { Strongly } \\
\text { Disagree }\end{array}$ & Disagree & $\begin{array}{c}\text { Slightly } \\
\text { Disagree }\end{array}$ & Neutral & $\begin{array}{c}\text { Slightly } \\
\text { Agree }\end{array}$ & Agree & $\begin{array}{c}\text { Strongly } \\
\text { Agree }\end{array}$ \\
\hline 1 & 2 & 3 & 4 & 5 & 6 & 7
\end{tabular}

\section{Generally, in stressful situations...}

1. I weigh out many options before choosing how to take action.

2. I can't focus on anything when I am upset.

3. It's hard to think of different ways of dealing with the situation

4. I control my thoughts and feelings by putting the situation in context.

5. I anticipate the consequences of my actions before acting.

6. I can remain in control over my thoughts and emotions.

7. It's difficult let go of intrusive thoughts or emotions.

8. It's hard for me to put things in perspective when I'm upset.

9. My thoughts and emotions become too much to deal with.

10. I have a hard time managing my emotions.

11. I take the time to see things from different perspectives before reacting.

12. I keep playing the situation over and over again in my head

13. I consider the situation for multiple viewpoints before responding.

14. I feel like I lose control over my thoughts and

$\begin{array}{lllllll}1 & 2 & 3 & 4 & 5 & 6 & 7\end{array}$

$\begin{array}{lllllll}1 & 2 & 3 & 4 & 5 & 6 & 7 \\ 1 & 2 & 3 & 4 & 5 & 6 & 7\end{array}$

$\begin{array}{lllllll}1 & 2 & 3 & 4 & 5 & 6 & 7\end{array}$

$\begin{array}{lllllll}1 & 2 & 3 & 4 & 5 & 6 & 7\end{array}$

$\begin{array}{lllllll}1 & 2 & 3 & 4 & 5 & 6 & 7\end{array}$

$\begin{array}{lllllll}1 & 2 & 3 & 4 & 5 & 6 & 7\end{array}$

$\begin{array}{lllllll}1 & 2 & 3 & 4 & 5 & 6 & 7\end{array}$

$\begin{array}{lllllll}1 & 2 & 3 & 4 & 5 & 6 & 7\end{array}$

$\begin{array}{lllllll}1 & 2 & 3 & 4 & 5 & 6 & 7 \\ 1 & 2 & 3 & 4 & 5 & 6 & 7\end{array}$

$\begin{array}{lllllll}1 & 2 & 3 & 4 & 5 & 6 & 7\end{array}$

$\begin{array}{lllllll}1 & 2 & 3 & 4 & 5 & 6 & 7\end{array}$

$\begin{array}{lllllll}1 & 2 & 3 & 4 & 5 & 6 & 7\end{array}$ 
emotions.

15. It's hard for me to shift my attention away from $\begin{array}{lllllll}1 & 2 & 3 & 4 & 5 & 6 & 7\end{array}$ negative thoughts or feelings.

16. I find it easy to look for something positive, even when I am stressed.

17. I control negative thoughts and emotions by modifying the way I think about the situation.

18. I get rid of negative thinking by re-evaluating the situation.

19. I think of a plan of what to do best before acting.

20. It is easy for me to ignore distracting thoughts.

21. It's hard for me to ignore negative emotions once they have been provoked.

22. I can think of multiple coping options before deciding how to respond.

23. I look for many strategies of dealing with the situation.

24. I get rid of negative emotions by changing the way I think about the situation.

25. I play out the consequences of various actions before choosing the best one.

26. I get easily distracted by upsetting thoughts or feelings.

27. I approach the situation from multiple angles.

28. My thoughts and emotions interfere with my ability to concentrate.

29. I take the time to think of more than one way to resolve the problem.

30. It is easy for me to shift my attention to other things if I am upset.

31. I can easily deal with my thoughts and feelings.

32. I play out the situation in my mind before responding.

33. I manage my thoughts or feelings by reframing the situation.

34. I find it difficult to think of many options for resolving the situation. 
35. The same thoughts keep going through my mind again and again.

36. I can't stop dwelling on my feelings.

37. My thoughts repeat themselves over and over again.

38. Putting a positive spin on a bad experience comes fairly easy to me.

39. I have difficulty controlling my thoughts and emotions.

40. I can't think about anything else except for the situation.

41. I find it easy to set-aside unpleasant thought or emotions.

42. It is easy for me to reassess a negative experience into a positive one.

43. I can easily to suppress upsetting memories.

44. I take the time to think of several ways to best cope with the situation before acting.

\begin{tabular}{|c|c|c|c|c|c|c|c|c|}
\hline 1 & 2 & 3 & 4 & & 5 & 6 & & 7 \\
\hline 1 & 2 & & 3 & 4 & 5 & & & 7 \\
\hline 1 & 2 & & 3 & 4 & 5 & & & 7 \\
\hline 1 & 2 & & 3 & 4 & 5 & & & 7 \\
\hline 1 & 2 & 3 & 4 & & 5 & 6 & & 7 \\
\hline 1 & 2 & & 3 & 4 & 5 & & & 7 \\
\hline 1 & 2 & & 3 & 4 & 5 & & & 7 \\
\hline 1 & 2 & 3 & 4 & & 5 & 6 & & 7 \\
\hline 1 & 2 & & 3 & 4 & 5 & & & 7 \\
\hline 1 & 2 & & 3 & 4 & 5 & & & 7 \\
\hline 1 & 2 & & 3 & 4 & 5 & & & 7 \\
\hline
\end{tabular}




\section{Cognitive Style Questionnaire - Short Form (CSQ-SF)}

Please try vividly to imagine yourself in each of the situations that follow. Picture each situation as clearly as you can as if the events were happening to you right now. Place yourself in each situation and decide what you feel would have caused that situation if it actually happened to you. Although the events may have many causes, we want you to choose only one - the thing you feel would be the major cause of the situation if it actually happened to you.

It is important to remember that there are no right or wrong answers to the questions. The important thing is to answer the questions in a way that corresponds to what you would think and feel if the situations occurred in your life. 


\section{Imagine you are getting along badly with your parents}

Think carefully about the reason for you getting along badly with your parents, then answer the questions below

\section{Strongly \\ Agree}

1. Getting along badly with my parents is caused by other people or circumstances*

2. The reason I get on badly with my parents causes problems in all areas of my life

3. My parents and I will start afresh in the future and forget about the reason for getting along badly*

4. Getting along badly with my parents will lead to other negative things happening to me

5. Getting along badly with my parents means there is something wrong with me as a person

6. It is my fault if I am getting along badly with my parents

7. The reason I get on badly with my parents does not stop me from enjoying other things*

8. The reason for getting along badly will stop me from getting along well with my parents in the future

9. Getting along badly with my parents does not say anything about me as a person*
Agree

Undecided

Disagree

Strongly

Disagree 
2. Imagine your class reacts negatively to an important talk you have to give as part of your coursework

Think carefully about the reason for the class reacting negatively to your talk, then answer the questions below

Strongly

Agree

1. It is not my fault that people reacted negatively*

2. The reason people reacted negatively to my talk will cause failures in all areas of my life

3. The reason people reacted negatively to this talk means that others will react negatively to talks I give in the future

4. People reacting negatively to my talk will not lead to other negative things happening to $\mathrm{me}^{*}$

5. The fact that people reacted negatively to this talk says nothing about me as a person*

6. The reason for the negative reaction was not caused by other people or circumstances

7. The reason that caused people to react negatively applies only to this talk*

8. Talks I give in the future will not be affected by the reason people reacted badly to this talk*

9. The fact that people reacted negatively to this talk says a lot about me as a person

\section{Agree}

Undecided

Strongly

Disagree 
3. Imagine that during the first year of working in the career of your choice, you receive a negative evaluation of your job performance Think carefully about the reason for you getting a negative evaluation, then answer the questions below

1. Other people or circumstances did not cause me to get a negative evaluation

2. The reason I got a negative evaluation applies only to this judgement about my job performance*

3. My job evaluations in the future will be affected by the same reason that caused this negative evaluation

4. This negative evaluation will lead to other negative things happening to me

5. This negative evaluation means there is something wrong with me as a person

6. It is my fault that I got this negative evaluation

7. The reason for getting this negative evaluation will not cause failures in all areas of my life*

8. The reason for this negative evaluation will not impact on my future job evaluations*

9. The fact that I got a negative evaluation says nothing about me as a person*

Strongly

Agree

$\square$

$\square$

$\square$

$\square$

$\square$

Agree

Undecide Disagree

Strongly
Disagree

$\square$

$\square$ 


\section{Imagine you go to a party and people are not interested in you}

Think carefully about the reason for people not being interested in you, then answer the questions below

Strongly

Agree

1. It is not my fault that people are not interested in me*

2. The reason for people not being interested in me applies only to this party*

3. If I go to a party like this in the future, things will be different and people will be interested in me*

4. People not being interested in me at this party will not lead to other negative things happening to $\mathrm{me}^{*}$

5. People not being interested in me at this party does not mean there is something wrong with me as a person*

6. The reason for people not being interested in me was not caused by other people or events at the party

7. The reason for people not being interested in me at this party will cause problems in all areas of my life

8. The reason people weren't interested in me at this party will cause people at parties in the future not to be interested in me

9. People not being interested in me at this party says a lot about me as a person
Agree

Undecided Disagree

Strongly

Disagree

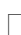


5. Imagine you really want to be in an intimate, romantic relationship, but you aren't

Think carefully about the reason for you not being in a relationship, then answer the questions below

1. Other people or circumstances have caused me not to be in an intimate, romantic relationship*

2. The reason that causes me not to be in a relationship applies only to intimate, romantic relationships*

3. The reason that causes me not to be in a relationship will have no impact on my future relationships*

4. Not being in an intimate, romantic relationship will lead to other negative things happening to me

5. Not being in an intimate, romantic relationship means there is something wrong with me as a person

6. It is my fault if I am not in an intimate, romantic relationship

7. The reason that causes me not to be in a relationship leads to problems in all areas of my life

8. The reason that causes me not to be in a relationship will mean I will not have an intimate, romantic relationship in the future

9. Not being in intimate, romantic relationship says nothing about me as a person*

Strongly

Agree

Agree

Undecided

Disagree

Strongly

Disagree

$$
\square
$$

(1)

$+$

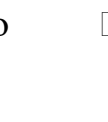




\section{Imagine that in an important class, you can't complete all the work that your teacher expects of you}

\section{Think carefully about the reason for you failing to complete the work, then answer the questions below}

Strongly

Agree

\section{Agree}

Undecided
Strongly

Disagree

1 It is not my fault that I failed to complete the work*

2 The reason for not completing the work will cause problems in all areas of my life

3 The reason I failed to complete the work will cause similar failure in completing work in classes in the future

4 Failing to complete the work will not lead to other negative things happening to me*

5 Failing to complete this work says a lot about me as a person

6 Other people or events caused me not to complete the work*

7 The reason for failing to complete the work applies only to this class*

8 The reason I failed to complete this work will not impact on whether I complete work in future classes*

9. Not completing this work says nothing about me as a person* 
7. Imagine a person you'd really like to develop a close friendship does not want to be friends with you

Think carefully about the reason for the person not wanting to be friends with you, then answer the questions below

Other people or circumstances have caused this person not to want to be my friend*

2 The reason that causes this person not to want to be my friend applies only to this friendship*

3 The reason that causes this person not to want to be my friend will always prevent this person from becoming my friend

4 This person not wanting to be my friend will lead to other negative things happening to me

5 This person not wanting to be my friend means there is something wrong with me as a person

6 It is my fault that this person does not want to be my friend

7 The reason that causes this person not to want to be my friend leads to problems in all areas of my life

8 This person may feel differently about the reason that caused them not to want to be my friend, and become my friend in the future*

9 This person not wanting to be my friend says nothing about me as a person*

Strongly

Agree

Agree

Undecided

Disagree

Strongly
Disagree

$\square$

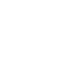

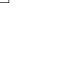




\section{Imagine you are unhappy}

Think carefully about the reason for you being unhappy, then answer the questions below

Strongly

Agree

Agree
Undecided

Disagree

Strongly

Disagree

1. My unhappiness is caused by other people or circumstances*

2. The reason for my unhappiness affects only my mood*

3. The reason for my unhappiness will always cause me to be unhappy

4. Being unhappy will not lead to other negative things happening to me*

5. Being unhappy does not mean there's something wrong with me as a person*

6. It is my fault that I am unhappy

7. The reason I'm unhappy causes problems in all areas of my life

8. The reason why I'm unhappy will go away and never cause me to be unhappy in the future*

9. Being unhappy says a lot about me as a person 


\section{Ruminative Responses Scale (RRS)}

Using the scale provided choose the corresponding numerical representation that best describes your own general attitude and feelings when faced with problems. Please fill in the appropriate number in the space provided next to each question.
Almost Never
Sometimes
3
Almost Always

Please indicate what you generally do, not what you think you should do.

\section{When you encounter problems, you:}

1. think about how alone you feel

2. think "I won't be able to do my job if I don't snap out of this."

3. think about your feelings of fatigue and achiness

4. think about how hard it is to concentrate

5. think "What am I doing to deserve this?"

6. think about how passive and unmotivated you feel

7. analyze recent events to try to understand why you are depressed

8. think about how you don't seem to feel anything anymore

9. think "Why can't I get going?"

10. think "Why do I always react this way?"

11. go away by yourself and think about why you feel this way

12. write down what you are thinking and analyze it

13. think about a recent situation, wishing it had gone better

14. think "I won't be able to concentrate if I keep feeling this way."

15. think "Why do I have problems other people don't have?"

16. think "Why can't I handle things better?"

17. think about how sad you feel

18. think about all your shortcomings, failings, faults, mistakes

19. think about how you don't feel up to doing anything

20. analyze your personality to try to understand why you are depressed

21. go someplace alone to think about your feelings

22. think about how angry you are with yourself 


\section{Rivermead Post Concussion Symptoms Questionnaire}

After a head injury or accident some people experience symptoms which can cause worry or nuisance. We would like to know if you now suffer from any of the symptoms given below. As many of these symptoms occur normally, we would like you to compare yourself now with before the accident. For each one, please circle the number closest to your answer.

$\begin{array}{ccccc}\begin{array}{c}\text { Not experienced at } \\ \text { all }\end{array} & \begin{array}{c}\text { No more of a } \\ \text { problem }\end{array} & \text { A mild problem } & \begin{array}{c}\text { A moderate } \\ \text { problem }\end{array} & \text { A severe problem } \\ 0 & 1 & 2 & 3 & 4\end{array}$

Compared with before the accident, do you now (i.e., over the last 24 hours) suffer from:

Headaches

$$
01234
$$

Feelings of Dizziness

01234

Nausea and/or Vomiting 01234

Noise Sensitivity, easily upset by loud noise 01234

Sleep Disturbance 01234

Fatigue, tiring more easily 01234

Being Irritable, easily angered 01234

Feeling Depressed or Tearful 01234

Feeling Frustrated or Impatient 01234

Forgetfulness, poor memory 01234

Poor Concentration 01234

Taking Longer to Think 01234

Blurred Vision 01234

Light Sensitivity, Easily upset by bright light 01234

Double Vision

01234 
Restlessness ........................................................ 01234

Are you experiencing any other difficulties?

1. 01234

2. 01234

3. 01234

How long, since the accident, have you experienced these symptoms?

$\square 1$ day to 1 week

$\square 1$ week to 1 month

$\square 1$ month to 2 months

$\square 2$ months to 3 months

$\square$ More than 3 months 